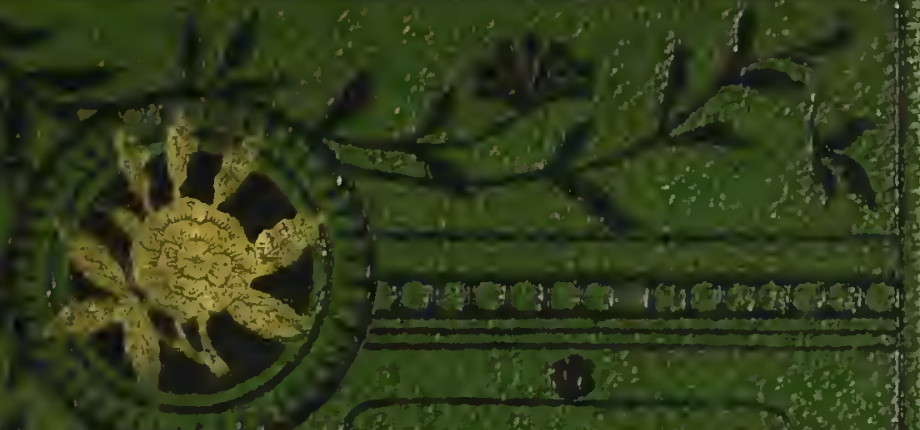

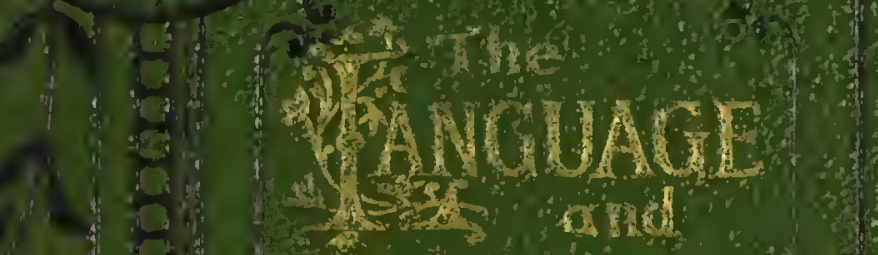
OOPOKY

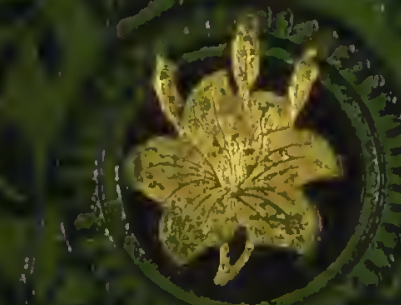

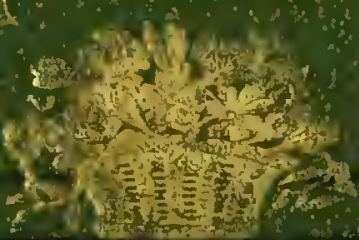




\section{ALBERT R. MANN \\ LIBRARY \\ AT \\ CORNELL UNIVERSITY}

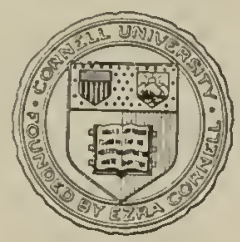

THE GIFT OF

Isabel Zucker

class ' 26 




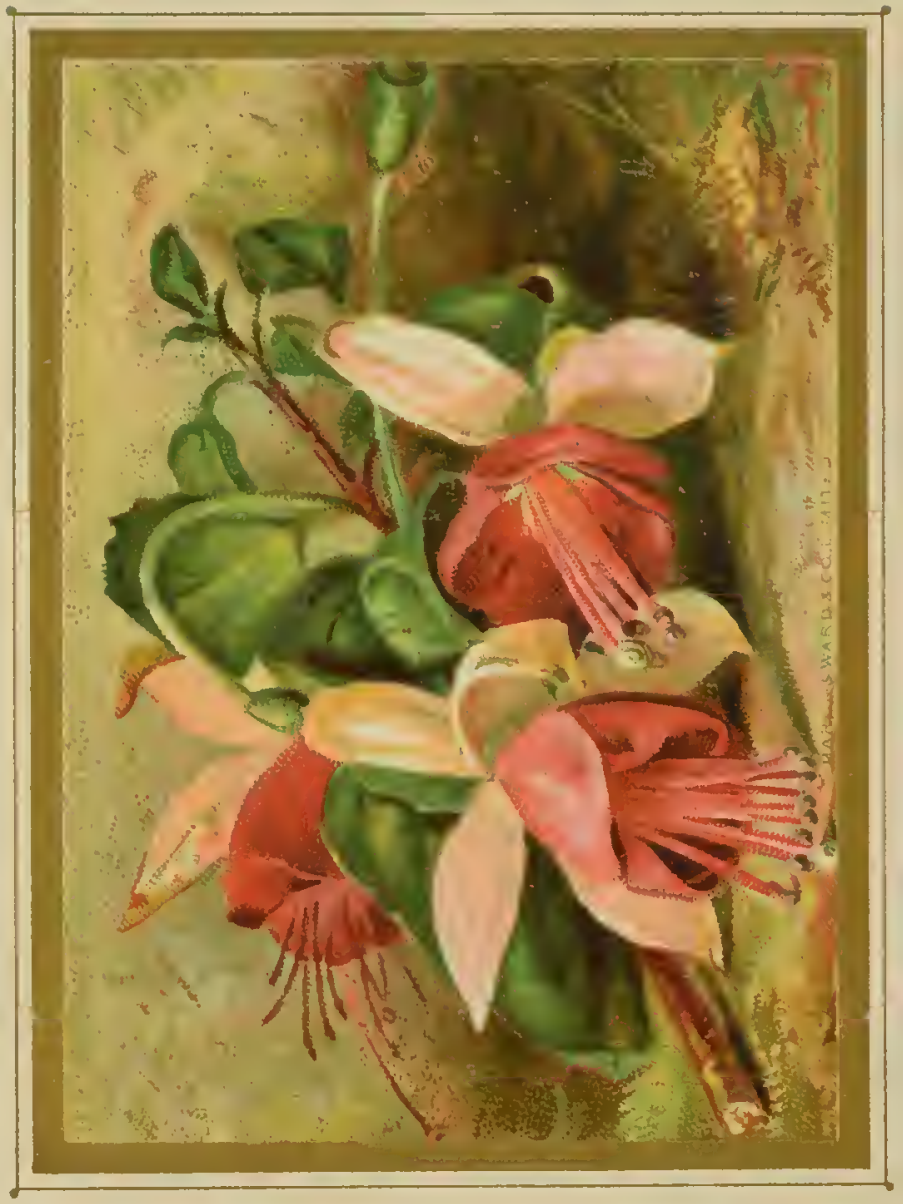




\title{
THE LANGUAGE
}

\author{
$A N D$
}

POETRY OF FLOWERS

Quitity deforal alluminations PRINTED IN COLOURS AND GOLD

FORTY-IOURTI

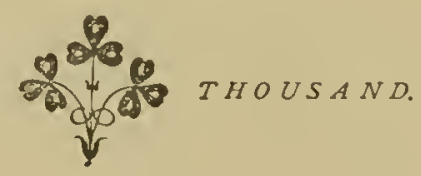

\section{亚an๖an:}

MARCUS WARD \& CO., LIMITED ORIEL HOUSE, FARRINGDON STIEET AND AT BELFAST AND NEW YORK I885 


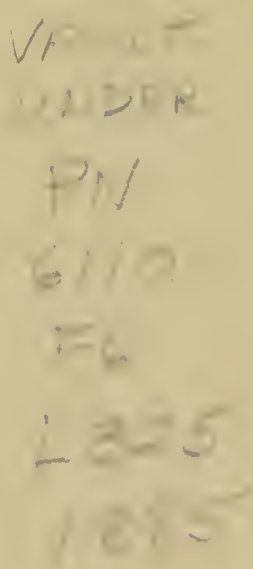




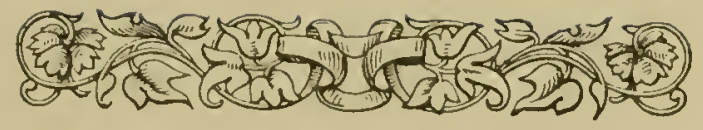

\section{CONTENTS.}

\section{THE POETRY OF FLOWERS.}

Hymn to the Flowers Page

'The Wreath • • • 7

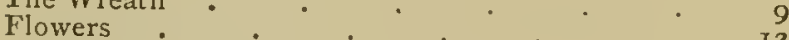

The Sensitive Plant . $\cdot{ }^{\circ} \quad$ I2

To the Small Celandine $\cdot r_{3}$

The Ivy

The Violet.

The Cypress Wreath .

Bring Flowers

Trausplanted Flowers

To the Bramble Flower

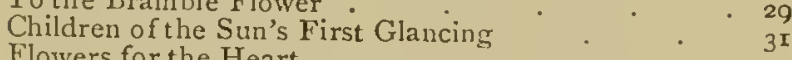

The Amaranth • • • . 32

The Last Rose of Summer • • •

The Winter Nosegay • • •

The Almond-Tree • • . 34

The Lily • • •

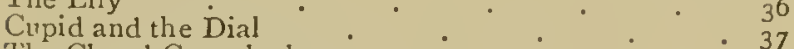

The Closed Convolvulus . . . $\quad \begin{aligned} & 37 \\ & 37\end{aligned}$

\begin{tabular}{ll} 
The Dying Boy to the Sloe Blossom . & 37 \\
\hline & $\cdot$
\end{tabular}

$\begin{array}{lll}\text { Songs and Chorus of the Flowers . } & \cdot & 39 \\ & & 4 I\end{array}$ 
The Narcissus

On receiving a Branch of Mezercon . . $\quad 48$

The Little Red Rose . . . . . 50

Wild Flowers. . . . 5 I

Cupid inspiring Plants with Love . . $\quad . \quad 52$

The Alpine Violet . . . . . 53

To a Daisy . . . . . . . . 54

The Ivy Song . . . . . . . 54

Daffodils . . . . . . . . $\quad 5^{6}$

Adonis' Couch . . . . . . . 57

Sonnet . . . . . . . 58

The Flower-Dial . . . . 59

Spring Flowers . . . . . . 60

Bowing Adorers . . . . . . . 60

Fragment. . . . . . 6 I

To a Mountain Daisy . . . 6r

The Broken Flower . . . . . 63

The Rose and the Gauntlet . . . . 64

The Rose . . . . . . . 65

Heart's-ease . . . . . 66

The Moss-Rose . . . . . . 66

The Hyacinth . . . . . . 67

The Queen of the Garden . . . . 68

The Cowslip . . . . 68

To the Round-leafed Sundew . . . . 69

A Cypress Leaf . . . . . . $77^{\circ}$

Wild Flowers $. \quad . \quad . \quad . \quad . \quad . \quad 73$

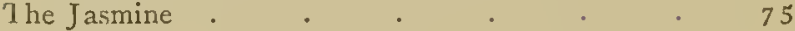

To Prinuroses . . . . . . . 75

The Daisy . . . . . . . . $\quad 7_{76}$

From Metastasio . . . . . . $\quad .77$

The Narcissus. . . . . . . 77

A Song of the Rose . . . . . 78

The Rose . . . 80

The Captive and the Flowers . . 80

Fragment . . . . . . . 833

I send the Lilies given to me . . . 84

The Furze . . . . . . 34

To Daffodils . . . . . . . . 85

To the Primrose . . . . . 86 
Faded Flowers

rage

The Roses

To the Snowdrop .

To the Jessamine

On a Faded Violet

Dawn, Gentle Flower

The Lily and the Rose

The Violet

The Dying Girl and Flowers

The Nightshade

The Lay of the Rose

Emblems of Flower:

90

The Orange-Bough

'T'o the Narcissus

The Harebell

The Half-blown Rose

$9 \mathrm{r}$

$9^{2}$

93

93

- 94

9.5

- 96

97

- 98

I04

- 105

I 06

- 107

107

'To the Daisy

Love's Wreath

To a Crocus

I08

IIO

Arrangement of a Bouquet . . . . II3

On Planting a Tulip-Root . . . . II4

T'o Blossoms

The Early Primrose

The Holly

Anacreon to the Rose

Decision of the Flower

The Shepherd to the Flowers

I 15

- II6

I 6

- II7

II9

- II9

I 20

Heart's-ease

The Scarlet Geranium

The Heliotrope

Amour of the Rose

I 20

122

- 122

The Forget-me-not

I 23

The Evening Primrose

- 124

'T'o an Early Primrose

I25

I26

I 28

The Garland

I20

I 3 I

To the Snowdrop

Heart's-ease

I 33

The Rose 
"Go to the Forest Shade"

The Primrose of the Rock

The Rose.

The Violet

Field Flowers

The Honeysuckle

To the Passion-Flower

The Lily of the Valley

- 134

I 36

- 137

138

. 140

I 40

- 142

143

- 144

I 45

\section{THE LANGUAGE OF FLOWERS.}

Part First .

- $4^{8}$

Part Second

Modifications of the Flower Language . Bouquets

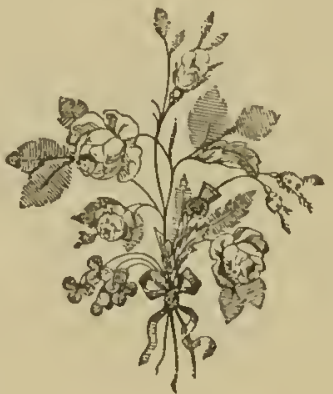

- Igo I I I 


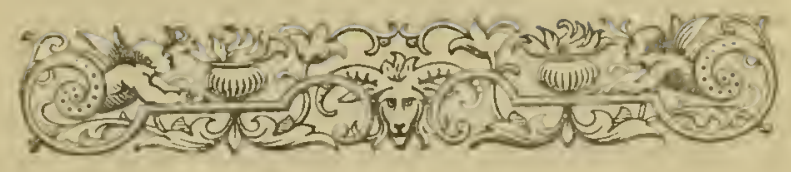

\section{THE POETRY OF FLOWERS.}

\section{HYMN TO THE FLOWERS.}

BY HORACE SMITH.

DAY-STARS ! that ope your eyes with man, to twinkle

From rainbow galaxies of earth's creation, And dew-drops on her holy altars sprinkle As a libation.

Ye matin worshippers ! who, bending lowly Before the uprisen sun, God's lidless eye! Throw from your chalices a sweet and holy Incense on high.

Ye bright Mosaics! that with storied beauty The floor of Nature's temple tesselate With numerous emblems of instructive duty Your forms create.

'Neath cloistered boughs, each floral bell that swingeth,

And tolls its perfume on the passing air, Makes Sabbath in the fields, and ever ringeth A call to prayer. 
Not to the domes where crumbling arch and column Attest the fecbleness of mortal hand, But to that fane, most catholic and solemn, Which God hath planned.

To that cathedral, boundless as our wonder,

Whose quenchless lamps the sun and moon supply; Its choir the winds and waves-its organ thunderIts dome the sky.

There as in solitude and shade I wander,

Through the green aisles, or stretched upon the sod, Awed by the silence, reverently ponder

The ways of God.

Your voiceless lips, O flowers! are living preachers,

Each cup a pulpit, and each leaf a book, Supplying to my fancy numcrous tcachers From loneliest nook.

Floral apostles! that in dewy splendour,

"Weep without woe, and blush without a crime,"

O may I deeply learn, and ne'er surrender

Your lore sublime!

"Thou wert not, Solomon, in all thy glory,

Arrayed," the lilies cry, "in robes like ours ;

How vain your grandeur! ah, how transitory Are human flowers!"

In the sweet-scented pictures, heavenly Artist !

With which Thou paintest Nature's widespread hall What a delightful lesson Thou impartest Of love to all!

Not useless are ye, flowers, though made for pleasure, Blooming o'er field and wave by day and night, From every source your sanction bids me treasure Harmless delight. 


\section{The Poetry of Flowers.}

Ephemeral sages ! what instructors hoary

For such a world of thought could furnish scopc?

Each fading calyx a memento mori,

Yet fount of hope.

Posthumous glories! angcl-like collection!

Upraised from seed or bulb interred in earth, Ye are to me a type of resurrection,

A second birth.

Were I, O God! in churchless lands remaining,

Far from all voice of teachers or divincs,

My soul would find in flowers of thy ordaining,

Priests, sermons, shrines!

\section{THE WREATH.}

TO A FRIEND ON HER BIRTHDAY.

BY WILLIAM PETERS.

LET others sing the rich, the great,

The victor's palms, the monarch's state,

A purer joy be mine-

To greet the excellent of earth,

To call down blessings on thy worth, And, for the hour that gave thee birth,

Life's choicest flowers entwine.

And lo ! wherc smiling from above (Meet helpmate in the work of love)

O'er opening hill and lawn,

With flowerets of a thousand dyes,

With all that's sweet of earth and skics,

Soft brcathes the vcrnal dawn.

Come! from her stores we'll cull the best, Thy bosom to adorn; 
Each leaf in livelier verdure drest, Each blossom balmier than the rest,

Each rose without a thorn;

Fleet tints, that with the rainbow died, Brief flowers, that withered in their pride, Shall, blushing into light, awake And kindlier bloom, for thy dear sake.

And first--though oft, alas ! condemned, Like merit, to the shadcThe Primrose meek, with dews begenmed Shall sparkle in the braid; And there, as sisters, side by side (Genius with modesty allied), 'The Pink's bright red, the Violet's blue, In blended rays, shall greet our view, Each lovelier for the other's hue.

How soft yon Jasmine's sunlit glow, How chaste yon Lily's robe of snow, With Myrtle green inwove! Types, dcarest, of thyself and meOf thy mild grace and purity, And my unchanging loveOf grace and purity, like thine, And love, undying love, like mine.

In fancifully-plumed array, As ever cloud at set of day, All azure, vermil, silver-grey,

And showering thick perfume; See how the Lilac's clustered spray

Has kindled into bloom, Radiant as Joy, o'er troubles past, And whispering, "Spring is come at last I" 
Blest Flowers ! There breathes not one unfraught

With lessons sweet and new ;

The Rose, in Taste's own garden wrought ;

The Pansy, nurse of tender thought ;

The Wallflower, tried and true ;

The purple Heath, so lone and fair,

(O how unlike the world's vain glare!)

The Daisy, so contently gay,

Opening her eyelids with the day ;

The Gorse-bloom, never sad or sere,

But golden bright,

As gems of night,

And fresh and fragrant all the year;

Each leaf, each bud of classic lore,

Oak, Hyacinth, and Floramore ;

The Cowslip, graceful in her woe ;

The Hawthorn's smile, the Poppy's glow,

This ripe with balm for present sorrow,

And that with raptures for to-morrow.

The flowers are culled; and each lithe stem

With Woodbine band we braid-

With Woodbine, type of Life's best gem,

Of Truth that will not fade.

The wreath is wove; do Thou, blest Power,

That brood'st o'er leaflet, fruit, and flower,

Embalm it with Thy love;

O make it such as angels wear,

Pure, bright, as decked earth's first-born pair,

Whilst free in Eden's grove,

From herb and plant they brushed the dew,

And neither sin nor sorrow knew. 


\section{F L OWER S : \\ SEN T ME DURING ILLNESS.}

BY RICHARD H. DANA.

I LOVED you ever, gentle flowers, And made you playmates of my youth ;

The while your spirit stole

In secret to my soul,

To shed a softness through my ripening powers, And lcad the thoughtful inind to dcepcst truth.

And now, when weariness and pain Had cast you almost from my breast,

With each a smiling face,

In all your simple grace,

You come once more to talkc me back again From pain to ease, from wcarincss to rcst.

Kind visitants ! through my siclz-room You scem to breathc an air of health,

And with you looks of joy

To wake again the boy,

And to the pallid cheek restore its bloom, And o'er the desert mind pour boundlcss wealth.

And whence ye came, by brimming streain, 'Neath rustling leaves, with birds within,

Again I musing tread-

Forgot my restless bed,

And long sick hours-Too short the blessed dream !

I woke to pain ! - to hcar thc city's din ! 
But time nor pain shall ever steal

Or youth or beauty from iny mind ;

And blessings on ye, flowers,

Though few with me your hours,

The youth and beauty and the heart to feel,

In her who sent you, ye will leave belind!

\section{THE SENSITIVE PLANT.}

\section{BY SHELLEY.}

PART I.

A Sensitive Plant in a garden grew, And the young winds fed it with silver dew ; And it opened its fan-like leaves to the light, And elosed them beneath the kisses of night.

And the spring arose on the garden fair, Like the spirit of love, felt everywhere!

And eaeh flower and herb on earth's dark breast Rose from the dreams of its wintry rest.

The Snowdrop, and then the Violet, Arose from the ground with warm rain wet; And their breath was mixed with fresh odour, sent From the turf, like the voice to the instrument.

Then the pied Wind-flowers, and the Tulip tall, And Nareissi, the fairest among them allWho gaze on their eyes in the stream's reeess, Till they die of their own dear loveliness !

And the naiad-like Lily of the Vale, Whom youth makes so fair, and passions so pale, That the light of its tremulous bells is seen Through their pavilions of tender green. 
And the Hyacinth, purple, and white, and blue,

Which flung from its bells a sweet peal anew

Of music so delicate, soft, and intense,

It was felt like an odour within the sense.

And the Rose, like a nymph to the bath addrest, Which unveiled the depth of her glowing breast, Till, fold after fold, to the fainting air The soul of her beauty and love lay bare.

And the wand-like Lily, which lifted up, As a Mænad, its moonlight-coloured cup, Till the fiery star, which is its eye,

Gazed through clear dew on the tender sky.

And the Jessamine faint, and the sweet Tuberose, The sweetest flower for scent that blows! And all rare blossoms, from every clime, Grew in that garden in perfect prime.

And on the stream, whose inconstant bosom Was prankt under boughs of embowering blossom, With golden and green light, and, starting through Their heaven of many a tangled hue,

Broad Water-lilies lay tremulously, And starry River-buds glimmered by,

And around them the soft stream did glide and dance

With a motion of sweet sound and radiance.

And the sinuous paths of lawn and moss, Which led through the garden along and acrossSome open at once to the sun and the breeze, Some lost among bowers of blossoming treesWere all paved with Daisies and delicate bells, As fair as the fabulous Asphodels, 


\section{The Poetry of Flowers.}

And flow'rets which, drooping as day drooped too, Fell into pavilions white, purple, and blue, To roof the glow-worm from the evening dew.

And from this undefiled paradise The flowers (as an infant's awakening eyes Smile on its mother, whose singing sweet Can first lull, and at last must awaken it), When heaven's blithe winds had unfolded them, As mine-lamps enkindle a hidden gem, Shone smiling to heaven, and every one Shared joy in the light of the gentle sun ;

For each one was interpenetrated

With the light and the odour its neighbour shed, Like young lovers, whom youth and love make dear, Wrapped and filled by their mutual atmosphere.

But the Sensitive Plant, which could give small fruit Of the love which it felt from the leaf to the root, Received more than all, it loved more than ever, Where none wanted but it, could belong to the giver.

For the Sensitive Plant has no bright flower;

Radiance and odour are not its dower; It loves, even like Love ; its deep heart is full ; It desires what it has not-the beautiful!

The light winds which, from unsustaining wings, Shed the music of many murmurings ; The beams which dart from many a star Of the flowers whose hues they bear afar;-

The plumèd insects, swift and free, Like golden boats on a sunny sea, Laden with light and odour, which pass Over the gleain of the living grass ;- 
The unseen clouds of the dcw, which lie Like fire in the flowcrs till the sun rides ligh, Then wander like spirits among the sphercs, Each cloud faint with the fragrance it bears;-

The quivering vapours of dim noon-tide, Which, like a sea, o'er the warm earth glide, In which every sound, and odour, and beam, Move as reeds in a singlc stream ; -

Each and all like ministering angels were, For the Scnsitive Plant swcet joy to bear: Whilst the lagging hours of the day went by, Like windless clouds o'er a tender sky.

And when evening descended from heaven above, And the earth was all rest, and the air was all love, And delight, though less bright, was far more deep, And the day's veil fell from the world of sleep ;

And the beasts and the birds and the insects were drowned

In an ocean of dreams without a sound ;

Whose waves never mark, though they ever impress.

The light sand which paves it-consciousness;

Only overhead the sweet nightingale Ever sang more sweet as the day night fail, And snatches of its Elysian chant

Were mixed with the dreams of the Sensitive Plant ;

The Scnsitive Plant was the earliest Upgathered into the bosom of restA sivcet child, weary of its delight, The feeblest, and yet the favourite, Cradled within the embrace of night. 


\section{PART II.}

There was a power in this sweet placeAn Eve in this Eden-a ruling grace, Which to the flowers, did they waken or dream, Was as God is to the starry scheme.

A lady - the wonder of her kind,

Whose form was upborne by a lovely mind, Which, dilating, had moulded her mien and motion, Like a sea-flower unfolded beneath the ocean-

Tended the garden from morn to even; And the meteors of that sublunar heaven, Like the lamps of the air when night walks forth, Laughed round her footsteps up from the earth !

She had no companion of mortal race,

But her tremulous breath and her flushing face Told, whilst the morn kissed the sleep from her eycs, That her dreams were less slumber than paradise.

As if some bright spirit for her sweet sake Had deserted heaven while the stars were awake ; As if yet around hor hc lingering were, Though the veil of daylight concealed him from her.

Her step seemed to pity the grass it prest ; You might hear by the heaving of her breast, That the coming and the going of the wind Brought pleasure there, and left passion behind.

And wherever her airy footstep trod, Her trailing hair from the grassy sod Erased its light vestige, with shadowy sweep, Like a sunny storm o'er the dark green deep. I doubt not the flowers of that garden sweet Rejoiced in the sound of her gentle fect; 
I doubt not they fclt the spirit that came From her glowing fingers through all their frame.

She sprinkled bright water from the strcam On those that were faint with the sunny beain ; And out of the cups of the heavy flowers She emptied the rain of the thunder-showers.

She lifted their heads with her tender hands, And sustained them with rods and osier bands ; If the flowers had been her own infants, she Could never have nursed them more tenderly.

And all killing insects and gnawing worms, And things of obscene and unlovely forms, She bore in a basket of Indian woof Into the rough woods far aloof-

In a basket of grasses and wild flowers full, The freshest her gentle hands could pull, For the poor banished insects, whose intent, Although they did ill, was innocent.

But the bee and the beam-like ephemeris,

Whose path is the lightning's, and the soft moths that kiss

The sweet lips of the flowers, and harm not, did she Make her attendant angels be.

And many an antenatal tomb,

Where butterflies dream of the life to come, She left clinging round the smooth and dark Edge of the odorous cedar bark.

This fairest creature, from earliest spring,

Thus moved through the garden, ministering, All the sweet season of the summer-tide, And ere the first leaf looked brown-she died. 
PART III.

Three days the flowers of the garden fair, Like stars when the moon is awakened, were ;

Or the waves of the Baize, ere, luminous, She foats up through the smoke of Vesuvius.

And on the fourth, the Sensitive Plant Felt the sound of the funcral chant, And the steps of the bcarers, heavy and slow, And the sobs of the mourners, deep and low;

The weary sound and the heavy breath, And the silent motions of passing death, And the smell, cold, oppressive, and dank, Sent through the pores of the coffin plank.

The dark grass, and the flowers among the grass, Were bright with tears as the crowds did pass; From their sighs the wind caught a mournful tone, And sate in the pines, and gave groan for groan.

The garden, oncc fair, became cold and foul, Like the corpse of her who had been its soul: Which at first was lovely, as if in sleep, Then slowly ehangcd, till it grew a heap To make men tremble who ncver weep.

Swift summer into the autumn flowed, And frost in the mist of the morning rodc, 'Though the noonday sun looked clear and bright, Moeking the spoil of the secret night.

The rosc-leaves, like flakes of crimson snow, Paved the turf and the moss bclow ;

The Lilies werc drooping, and white and wan, Like the head and skin of a dying man. 
And the Indian plants, of scent and hue, The sweetest that ever were fed on dew,

Leaf after leaf, day by day,

Were massed into the common clay.

And the leaves, brown, yellow, and grey, and red, And white with the whiteness of what is dead, Like troops of ghosts on the dry wind passed; Their whistling noise made the birds aghast.

And the gusty winds waked the winged seeds Out of their birthplace of ugly weeds, Till they clung round many a sweet flower's stem, Which rotted in to earth with them.

The water-blooms under the rivulet Fell from the stalks on which they were set; And the eddies drove them here and there, As the winds did those of the upper air.

Then the rain came down, and the broken stalks Were bent and tangled across the walks; And the leafless network of parasite bowers Massed into ruin, and all sweet flowers.

Betwecn the time of the wind and the snow, All loathliest weeds began to grow,

Whose coarse leaves were splashed with many a speck,

Like the water-snake's belly and the toad's back.

The Sensitive Plant, like one forbid, Wept, and the tears within each lid Of its folded leaves, which together grew, Were changed to a blight of frozen glue.

For the leaves soon fell, and the branches soon By the heavy axe of the blast were hewn; 
The sap shrank to the root through every pore, As blood to a heart that will beat no more.

For winter came : the wind was his whip, One choppy finger was on his lip ;

He had torn the cataracts from the hills, And they clanked at his girdle like manacles.

His breath was a chain, wlich, without a sound, The earth, and the air, and the water bound ; He came, fiercely driven in his chariot throne By the tenfold blasts of the Arctic zone.

Then the weeds, which were forms of living death, Fled from the frosts to the earth beneath; Their decay and sudden flight from frost Was but like the vanishing of a ghost !

And under the roots of the Sensitive Plant The moles and the dormice died for want ; And the birds dropped stiff from the frozen air, And were caught in the branches naked and bare.

First there came down a thawing rain, And its dull drops froze on the boughs again ; Then there steamed up a freezing dcw, Which to the drops of the thaw-rain grew ;

And a northern whirlwind, wandering about Like a wolf that had smelt a dead child out, Shook the boughs thus laden and heavy and stiff, And snapped them off with his rigid griff.

When winter had gone and spring came back, The Sensitive Plant was a leafless wreck ;

But the mandrakes, and toadstools, and docks, and darnels,

Rose, like the dead, from thcir buricd charnels. 
CONCLUSION.

Whether the Sensitive Plant, or that Which within its boughs like a spirit sat, Ere its outward form had known decay, Now felt this change, I cannot siy.

Whether that lady's gentle mind, No longer with the form combined, Which scattered love, as stars do light, Found sadness where it left delight,

I dare not guess; but in this life Of error, ignorance, and strife, Where nothing is, but all things seen, And we the shadows of the dream.

It is a modest creed, and yet Pleasant, if one considers it, To own that death itself must be, Like all the rest, a mockery.

That garden sweet, that lady fair, And all sweet shapes and odours there, In truth, have never passed away ; 'Tis we, 'tis ours are changed-not they.

For love, and beauty, and delight, There is no death nor change; their might Exceeds our organs, which endure No light, being themselves obscure. 


\section{TO THE SMALL CELANDINE.}

WORDSWORTH.

PAnsies, Lilies, King-cups, Daisies,

Let them live upon thcir praises;

Long as there's a sun that sets, Primroses will have their glory ;

Long as there are Violets,

They will have a place in story ;

There's a flower that shall be mine,

'Tis the little Celandine.

Ere a leaf is on the bush,

In the time before the thrush

Has a thought about her nest, Thou wilt come with half a call,

Spreading out thy glossy breast

Like a careless prodigal ;

Telling tales about the sun,

When we've little warmth, or none.

Comfort have thou of thy merit,

Kindly unassuming spirit !

Careless of thy neighboirhood,

Thou dost show thy pleasant face

On the moor, and in the wood,

In the lane-there's not a place,

Howsocver mean it be,

But 'tis good enough for thee.

Ill befall the yellow flowers,

Children of the flaring hours !

Buttercups that will be seen,

Whether we will see or no ;

Others, too, of lofty mien,

They have done as worldlings do, 
Taken praise that should bc thine,

Little, humble Celandine!

Prophet of delight and mirth,

Ill requited upon earth ;

Herald of a mighty band,

Of a joyous train ensuing,

Serving at my heart's command,

Tasks that are no tasks renewing ;

I will sing, as doth bchove,

Hymns in praise of what I love!

\section{TH E I V Y.}

BARTON.

HAST thou seen, in winter's stormiest day,

The trunk of a blighted oak,

Not dead, but sinking in slow decay

Beneath Time's resistless stroke,

Round which a luxuriant Ivy had grown,

And wreathed it with verdure no longer its own?

Perchance thou hast seen this sight, and then, As I at thy years might do,

Passed carelessly by, nor turned again

That scathed wreck to view ;

But now I can draw from that mouldering tree Thoughts which are soothing and dear to me.

Oh! smile not, nor think it a worthless thing.

If it be with instruction fraught ;

That which will closest and longest cling,

Is alone worth a serious thought. Should aught be unlovely, which thus can sled Grace on the dying, and leaves on the deacl? 


\section{THE VIOLET.}

FROM THE GERMAN OF GOETHE.

A Violet blossoined on the green, With lowly stem, and bloom unseen ;

It was a sweet, low flower. A shepherd maiden came that way, With lightsome step and aspect gay,

Came near, came near,

Caine o'er the green with song.

Ah ! thought the Violet, might I be The fairest flower on al! the lea,

Ah! but for one brief hour ;

And might be plucked by that dear maid, And gently on her bosom laid,

Ah! but, ah! but

A few dear moments long.

Alas! the maiden, as she passed,

No eye upon the Violet cast;

She crushed the poor wee flower.

It sank, and, dying, heaved no sigh,

And if I die, at least I die

By her, by her,

Beneath her feet I die.

\section{THE CYPRESS WREATH.}

BY SIR W. SCOTT.

O LADY! twine no wreath for me,

Or twine it of the Cypress tree;

Too lively grow the Lilies light,

The varnished Holly's all too bright. 
The May-flower and the Eglantine May shade a brow less sad than mine; But, lady, weave no wreath for me, Or weave it of the Cypress tree.

Let dimpled Mirth his temples twine With tendrils of the laughing Vine ; The manly Oak, the pensive Yew,

To patriot and to sage be due ; The Myrtle bough bids lovers live, Bist that Matilda will not give; Then, lady, twine no wreath for me, Or twine it of the Cypress tree.

Let merry England proudly rear Her blended koses, bought so dear; Let Albin bind her bonnet blue With Heath and Harebell dipped in dew : On favoured Erin's crest be seen The flower she loves of emerald greenBut, lady, twine no wreath for me, Or twine it of the Cypress tree.

Strike the wild harp, while maids prepare The Ivy, meet for minstrel's hair ; And while his crown of laurel leaves With bloody hand the victor weaves, Let the loud trump his triumph tell; But when you hear the passing bell, Then, lady, twine a wreath for me, And twine it of the Cypress tree.

Yes, twine for me the Cypress bough ; But, O Matilda! twine not nowStay till a few brief months are past, And I have looked and loved my last. 
When villagers my shroud bestrew

With Pansies, Rosemary, and Rue-

Then, lady, weave a wreath for me,

And weave it of the Cypress tree.

\section{BRING FLOWERS.}

\section{MRS. HEMANS.}

BRING flowers, young flowers, for the festal board, To wreathe the eup ere the wine is poured; Bring flowers! they are springing in wood and vale, Their breath floats out on the southern gale, And the touch of the sunbeam hath waked the Rose, To deek the hall where the bright wine flows.

Bring flowers to strew in the eonqueror's pathHe liath shaken thrones with his stormy wrath! He comes with the spoils of nations baek, The vines he erushed in his ehariot's traek, The turf looks red where he won the dayBring flowers to die in the eonqueror's way!

Bring flowers to the eaptive's lonely cell, They have tales of the joyous woods to tell ; Of the free blue streams, and the glowing sky, Ard the bright world shut from his languid eye; They will bear him a thought of the sunny hours, And a dream of his youth-bring him flowers, wild flowers!

Bring flowers, fresh flowers, for the bricle to wear ! They were worn to blush in lier shining hair; 
She is leaving the home of her ehildhood's mirth, She hath bid farewell to her father's hearth; Her place is now by another's sideBring flowers for the loeks of the fair young bride.

Bring flowers, pale flowers, o'er the bier to shed, A erown for the brow of the early dead!

For this through its leaves hath the Wild Rose burst, For this in the woods was the Violet nursed! Though they smile in vain for what onee was ours, They are love's last gift-bring ye flowers, pale flowers !

Bring flowers to the shrine where we kneel in prayer, They are Nature's offering, their place is there!

They speak of hope to the fainting heart, With a voiee of promise they eome and part, They sleep in dust in the wintry hours, They break forth in glory-bring flowers, bright flowers !

\section{TRANSPLANTED FLOWERS.}

BY E. ELLIOTT.

YE living gems of cold and fragrant fire! Die ye for ever, when ye die, ye flowers? liake ye, when in your beauty ye expire, An everlasting farewell of your bowers?

No more to listen for the wooing air, And song-brought morn, the eloud-tinged woodlands o'er!

No more to June's soft lip your breasts to bare, And drink fond evening's dewy breath no more । 
Soon fades the sweetest ; first the fairest dies, For frail and fair are sisters ; but the heart, Filled with deep love, Death's power to kill denies, And sobs e'en o'er the dead, "We cannot part!" Have I not seen thee, Wild Rose, in my dreams? Like a pure spirit-beauteous as the skies, When the clear blue is brightest, and the streams Danee down the hills, reflecting the rieh dyes Of morning elouds, and eistus woodbine-twinedDidst thou not wake me from a dream of death? Yea, and thy voice was sweeter than the wind When it inhales the love-siek Violet's breath, Bending it down with kisses, where the bee Hums over golden gorse and sunny broom. Soul of the Rose! what said'st thou then to me?

"We meet," thou said'st, "though severed by the tomb :

Lo, brother, this is heav'n! and thus the just shall bloom."

\section{TO THE BRAMBLE FLOWER.}

\section{BY E. ELLIOTT.}

THY fruit full well the sehoolboy knows, Wild Bramble of the brake!

So, put thou forth thy small white rose; I love it for his sake.

Though Woodbines flaunt and Roses glow O'er all the fragrant bowers,

Thou need'st not be ashamed to show Thy satin-threaded flowers; 
For dull the eye, the heart is dull That cannot feel how fair, Amid all beauty, beautiful Thy tender blossoms arc!

How delicate thy gauzy frill ! How rich thy branchy stem ! How soft thy voice when woods are still, And thou sing'st hymns to them;

While silent showers are falling slow, And, 'mid the goneral hush, A sweet air lifts the little bough, Lonc whispering through the bush!

The Primrose to the grave is gone; The Hawthorn flower is dead ; The Violet by the mossecl grey stone Hath laid her weary head;

But thou, Wild Bramble, back dost bring, In all their beauteous power, 'The fresh green days of life's fair spring, And boyhood's blossomy hour.

Scorned Bramble of the brake! once more 'Thou bidd'st me be a boy, To gad with thee the woodlands o'er, In freedom and in joy. 


\section{The Poetry of Flowers.}

\section{CHILDREN OF THE SUN'S FIRST GLANCING.}

FROM SCHILLER.

CHILDREN of the sun's first glancing, Flowers that deck the bounteous earth; Joy and mirth are round ye dancing, Nature smiled upon your birth ; Light hath veined your petals tender, And with hues of matchless splendour Flora paints each dewy bell; But lament, ye sweet spring blossoms, Soul hath never thrilled your bosoms, All in eheerless night ye dwell.

Nightingale and lark are singing Many a lay of love to you ; In your chaliced blossoms swinging, Tiny sylphs their sylphids woo;

Deep within the painted bower Of a soft and perfumed flower, Venus once did fall asleep ; But no pulse of passion darted Through your breast, by her impartedChildren of the morning, wcep. When my mother's harsh rcjection

Bids me eease my love to spcakPledges of a true affection, When your gentle aid I seek'Then by cvery voiceless token, Hope, and faith unclianged, are spoken, And by you my bosom grieves ; Love himself among you stealcth, And his awful form concealeth, Shut within your folding leaves. 


\section{FLOWERS FOR THE HEART.}

BY E. ELLIOTT.

FLowers ! winter flowers !-the child is dead,

The mother cannot speak ;

Oh, softly couch his little head,

Or Mary's heart will break!

Amid those curls of flaxen hair

This pale pink ribbon twine,

And on the little bosom there

Place this wan lock of mine.

How like a form in cold white stone,

The coffined infant lies!

Look, mother, on thy little one,

And tears will fill thine eyes.

She cannot weep, more faint she grows,

More deadly pale and still ;

Flowers! oh, a flower! a Winter Rose,

That tiny hand to fill.

Go, search the fields ! the lichen wet

Bends o'er th' unfailing well ;

Bencath the furrow lingers yet

The scarlet Pimpernel.

Peeps not a Snowdrop in the bower,

Where never froze the spring?

A Daisy? ah! bring childhood's flower! The half-blown Daisy bring !

Yes, lay the Daisy's little head

Beside the little cheek ;

Oh, haste! the last of five is dead !

The childless cannot speak ! 


\section{THE AMARANTH.}

\section{MILTON.}

CRowns inwove with Amaranth and gold, Immortal Amaranth, a flower which once In Paradise, fast by the Tree of Life, Began to bloom; but soon, for man's offence, To Heaven removed, where first it grew, there grows And flowers aloft, shading the Fount of Life, And where the River of Bliss, through midst of Heaven,

Rolls o'er Elysian flowers her amber stream ; With these, that never fade, the spirits elect Bind their resplendent locks.

\section{THE LAST ROSE OF SUMMER.}

BY T. MOORE.

"Tis the last Rose of summer Left blooming alone, All her lovely companions

Are faded and gone ; No flower of her kindred,

No Rosebud is nigh, To reflect back her blushes And give sigh for sigh.

I'll not leave thee, thou lone one, To pine on the stem ; Since the lovely are sleeping,

Go sleep thou with them. 
Thus kindly I scatter Thy leaves on the bed, Where thy mates of the garden Lie seentless and dead.

So soon may I follow

When friendships deeay, And from love's shining cirele

The gems drop away; When true hearts lie withered, And fond ones are flown, Oh! who would inhabit This cold world alone?

\section{THE WINTER NOSEGAY.}

BY WILLIAM COWPER.

What Naturc, alas! has denied 'To the delicatc growth of our isle, Art has in a measure supplied, And winter is decked with a smile. See, Mary, what beauties I bring

From the shelter of that sunny shed, Where the flowers have the charms of the spring Though abroad they are frozen and dead.

'Tis a bower of Arcadian sweets,

Where Flora is still in her prime, A fortress to which she retreats From the cruel assaults of the clime. While earth wears a mantle of snow, These pinks are as fresh and as gay As the fairest and sweetcst that blow

On the beautiful bosom of May. 


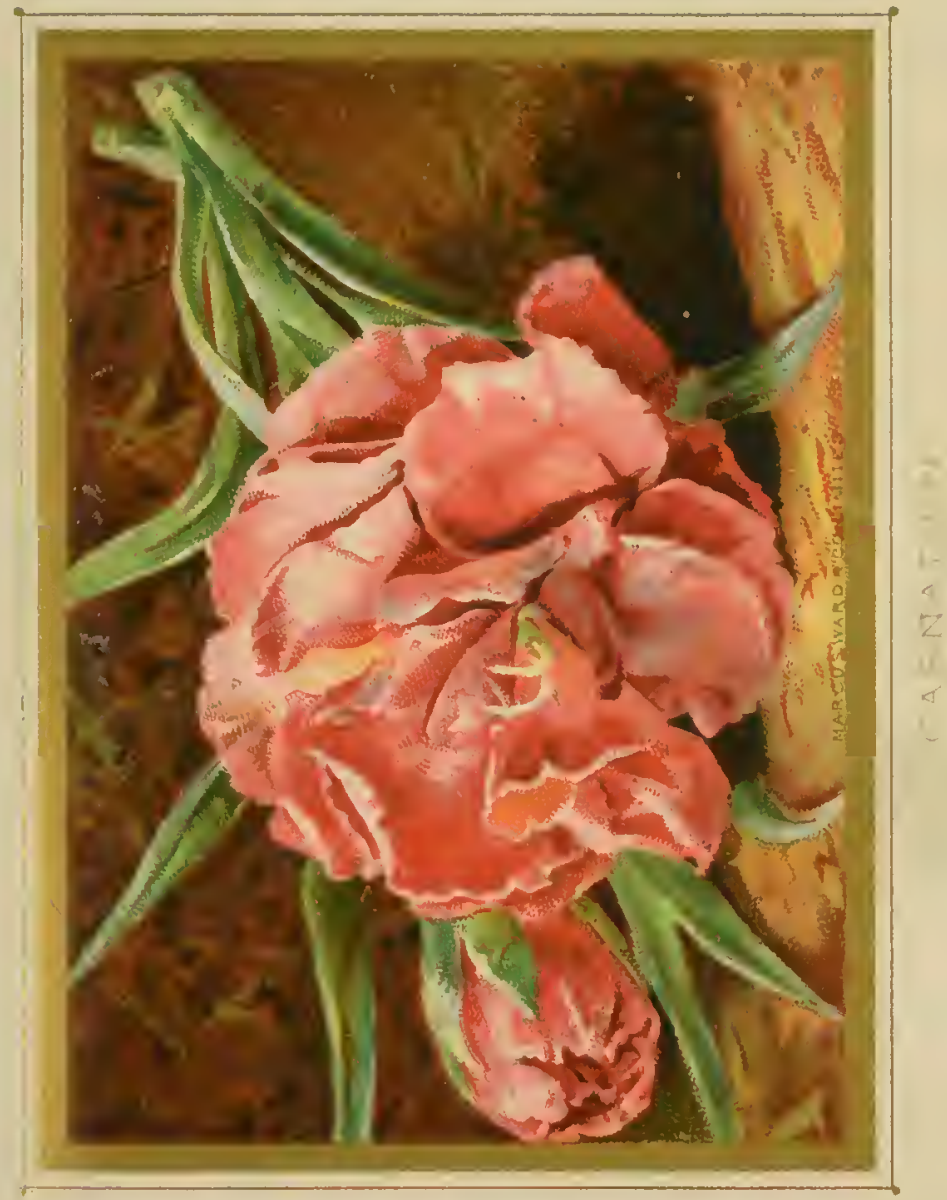



See how they have safely survived

'The powers of a sky so severe; Sueh Mary's true love, that has lived

Through many a turbulent year.

The eharms of the late-blowing Rose

Seem graeed with a livelier hue, And the winter of sorrow best shows

The truth of a friend such as you.

\section{THE ALMOND-TREE.}

\section{BY MISS LANDON.}

FLeETING and falling,

Where is the bloom

Of yon fair Almond-tree?

It is sunk in the tomb.

Its tomb wheresoever

The wind may have borne

The leaves and the blossoms

Its roughness has torn.

Some there are floating

On yon fountain's breast, Some line the moss

Of the nightingale's nest.

Some are just strewn

O'er the green grass below, And there they lie stainless

As winter's first snow.

Yesterday, on the boughs, They hung seented and fair ; To-day they are seattered

The breeze best knows where. 
To-morrow those leaves Will be scentless and dead,

For the kind to lament, And the eareless to tread.

And is it not thus

With each hope of the heart ?

With all its best feelings,

Thus will they depart.

They'll go forth to the world

On the wings of the air,

Rejoicing and hoping ;

But what will be there?

False lights to deeeive,

False friends to delude,

Till the heart in its sorrow 's

Left only to brood.

Over feelings erushed, ehilled.

Sweet hopes ever flown;

Like that tree when its green leaves

And blossoms are gone.

\section{T H E L I L Y.}

BY SAMUEL TAYLOR COLERIDGE.

THE stream with languid murmur creeps

In Lumin's flowery vale ;

Beıteath the dew the Lily weeps,

Slow waving to the gale. 
" Cease, restless gale!" it seems to say,

"Nor wake me with thy sighing!

The honours of my vernal day

On rapid wings are flying.

"To-morrow shall the traveiler come

Who late beheld me blooming :

His searching eye shall vainly roam

The dreary vale of Lumin."

\section{CUPID AND THE DIAL.}

ONE day, young frolic Cupid tried

'To scatter Roses o'er the hours,

And on the dial's face to hide

The course of time with many flowers.

By chance, his rosy wreaths had wound

Upon the hands, and forced them on ;

And, when he looked again, he found

The hours had passed, the time was done.

"Alas!" said Love, and dropped his flowers,

"I've lost my time in idle play;

The sweeter I would make the hours,

The quicker they are passed away."

\section{THE CLOSED CONVOLVULUS.}

AN hour ago, and sunny beams

Were glancing o'er each airy bell ; And thou wert drinking in those gleams,

Like beauty listening love's farewell. 
And now with folded drooping leaves, Thou seemest for that light to mourn, Like unto one who fondly grieves

The hours that stay some friend's return.

We cannot trace the hidden power Which folds thine azure petals up, When evening shadows dimly lower, And dewdrops gem each flow'ret's cup.

Methinks I should not wish to be Like thee, a votary of the sunTo bask beneath his beams, yet flee Whene'er his brilliant race is run.

Oh! dearer far the silent night, And lovelier far the starlit sky, Tlian gaudy day with sunbeams bright, And loud with Nature's minstrelsy.

The night-bird's song is not for thee, 'The beautiful, the silver moon, The holy calm o'er flowers and tree, 'The stillness-Nature's dearest boon.

Thou art a reveller of day, A fair, rejoicing child of light ;

Glad while the sunbeams o'er thee play, But drooping in the quiet night.

Like unto those who freely spend

Their kindness in our happier hours ; But, should affliction want a friend, They prove the sun's adoring flowers.

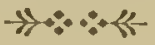




\section{THE DYING BOY TO THE SLOE BLOSSOM.}

BY E. ELLIOTT.

BEFORE thy leaves thou com'st once more,

White blossom of the Sloe!

Thy leaves will come as heretofore ;

But tnis poor heart, its troubles o'er, Will then lie low.

A month at least before thy time

Thou com'st, pale flower, to me ;

For well thou know'st the frosty rime

Will blast me ere my vernal prime,

No more to be.

Why here in Winter? No storm lours

O'er Nature's silent shroud!

But blithe larks meet the sunny showers,

High o'er the doomed untimely flowers

In beauty bowed.

Sweet Violets in the budding grove

Peep where the glad waves run ;

The wren below, the thrush above,

Of bright to-morrow's joy and love,

Sing to the sun.

And where the rose-leaf, ever bold,

Hears bees chant hymns to God,

The breeze-bowed palm, mossed o'er with gold,

Smiles o'er the well in summer cold,

And daisied sod.

But thou, pale blossom, thou art come,

And flowers in winter blow,

To tell me that the worm makes room

For me, her brother, in the tomb,

And thinks me slow. 
For as the rainbow of the dawn

Foretells an eve of tears,

A sunbeam on the saddened lawn,

I smile, and weep to be withdrawn

In early years.

Thy leaves will come, but songful Spring

Will see no leaf of mine ;

Her bells will ring, her bridesmaids sing,

When my young leaves are withering

Where no suns shine.

Oh ! might I breathe morn's dewy breath

When June's sweet Sabbaths chime!

But, thine before my time, O Death!

I go where no flow'r blossometh,

Before my time.

Ev'n as the blushes of the morn

Vanish, and long ere noon

The dewdrop dieth on the thorn,

So fair I bloomed; and was I born

To die as soon?

To love my mother, and to die-

To perish in my bloom !

Is this my sad, brief history?-

A tear dropped from a mother's eye

Into the tomb.

He lived and loved-will sorrow say-

By early sorrows tried;

He smiled, he sighed, he passed away,

His life was but an April day-

He loved, and died!

My mother smiles, then turns away,

But turns away to weep ; 
They whisper round me-what they say

I need not hear, for in the clay

I soon must sleep.

Oh, love is sorrow! sad it is

To be both tried and true;

I ever trembled in my bliss ;

Now there are farewells in a kiss-

They sigh adieu.

But Woodbines flaunt when Blue-bells fade,

Where Don reflects the skies ;

And many a youth in Shirecliffs' shade

Will ramble where my boyhood played,

Though Alfred lies.

Then panting woods the breeze will feel, And bowers, as heretofore,

Beneath their load of Roses reel ;

But I through Woodbine lanes shall steal

No more, no more.

Well, lay me by my brother's side,

Where late we stood and wept ;

For I was stricken when he died-

I felt the arrow as he sighed

His last, and slept.

\section{SONGS AND CHORUS OF THE FLOWERS.}

\section{BY LEIGH HUNT.}

ROSES.

WE are blushing Roses,

Bending with our fulness,

'Midst our close-capped sister buds,

Warming the green coolness. 
Whatsoe'er of beauty

Yearns and yet reposes,

Blush, and bosom, and sweet breath,

Took a shape in Roses.

Hold one of us lightly-

See from what a slender

Stalk we bower in heavy blooms, And roundness rich and tender.

Know you not our only

Rival flower-the human?

Loveliest weight on lightest foot, Joy-abundant woman?

LILIES.

We are Lilies fair,

The flower of virgin light ;

Nature held us forth, and said,

"Lo ! my thoughts of white."

Ever since then, angels

Hold us in their hands ;

You may see them where they take

In pictures their sweet stands.

Like the garden's angels

Also do we seem ;

And not the less for being crowned

With a golden dream.

Could you see around us

The enamoured air,

You would see it pale with bliss

To hold a thing so fair. 
POPPIES.

We are slumbering Poppies,

Lords of Lethè downs,

Some awake, and some asleep,

Sleeping in our crowns.

What perchancc our dreams may know,

Let our scrious beauty show.

Central depth of purple,

Leaves more bright than rose ;

Who shall tell what brightest thought

Out of darkest grows?

Who, through what funereal pain,

Souls to love and peace attain?

Visions aye are on us,

Unto eyes of power ;

Pluto's always-setting sun,

And Proserpine's bower ;

Thcre, like bees, the pale souls come

For our clrink, with drowsy lium.

Taste, ye mortals, also ;

Milky-hearted, we ;-

Taste, but with a reverent care,

Active-patient be.

Too much gladness brings to gloom

Those who on the gods prcsume.

\section{Chorus.}

We are the sweet flowers,

Born of sunny showers

(Think, whene'cr you sec us, what our beauty saith)-

Utterance, mute and bright,

Or some unknown dclight,

We fill the air with pleasure by our simple brcath. 
All who see us love us,

We befit all places-

Unto sorrow we give smiles, and unto graces races.

Mark our ways, how noiseless

All, and sweetly voiceless,

Though the March-winds pipe to make our passage clear ;

Not a whisper tells

Where our small seed dwells,

Nor is known the moment green when our tips appear.

We thread the earth in silence,

In silence build our bowers,

And leaf by leaf in silence show, till we laugh a-top, sweet flowers.

The dear lumpish baby,

Humming with the May-bee,

Hails us with his bright star, stumbling through the grass ;

The honey-dropping moon,

On a night in June,

Kisses our pale pathway leaves that felt the bridegroom pass.

Age, the withered clingcr,

On us mutely gazes,

And wraps the thought of his last bed in his child. hood's daisies.

See (and scorn all duller

Taste) how Heav'n loves colour ;

How great Nature clearly joys in red and green ;

What sweet thoughts she thinks

Of Violets and Pinks,

And a thousand flushing hues, made solcly to be scen. 
See her whitest Lilies

Chill the silver showers,

And what a red mouth is her Rose, the woman of her flowers!

Uselessness divinest,

Of a use the finest,

Painteth us, the teachers of the end of use ;

Travellers, wcary-eyed,

Bless us far and wide ;

Unto sick and prison thoughts we give sudden truce ;

Not a poor town window

Loves its sickliest planting,

But its wall speaks loftier truth than Babylonian vaunting.

Sagest yet the uses,

Mixed with our sweet juices,

Whether man or May-fly profit of the balm,

As fair fingers healed

Knights from the olden field,

We hold cups of mightiest force to give the wildest calm.

Even the terror, poison,

Hath its plea for blooming ;

Life it gives to reverent lips, though death to the presuming.

And oh! our sweet soul-taker,

That thief, the honcymakcr,

What a house hath he by the thymy glen!

In his talking rooms

How the feasting fumes,

Till the gold cups overflow to the mouths of men ; 
The butterflies come aping

Thosc fine thieves of ours, And flutter round our rifled tops, like tickled flowers with flowers.

See those tops, how beauteous !

What fair service duteous

Round some idol waits, as on their lord the Nine

Elfin court 'twould seem ;

And taught, perchance, that dream

Which the old Greek mountain dreamt, upon nights divine.

To expound such wonder

Human speech avails not;

Yet there dies no poorest weed that such a glory exhales not.

'Think of all these treasures,

Matchless works and pleasures,

Every one a marvel, more than thought can say ;

Then think in what bright showers

We thicken fields and bowers,

And with what hcaps of sweetness half-stifle wanton May ;

Think of the mossy forests

By the bce-birds haunted,

And all those Amazonian plains, lone lying as enclinnted.

Trees themselves are ours ;

Fruits are born of flowers;

Peach, and roughest nut, were blossoms in the spring ;

The lusty bee knows well

The news, and comes pell-mell,

And dances in the gloomy thicks with darksone an theming. 


\section{The Poetry of Flowers.}

Beneath the very burthen

Of planet-pressing ocean,

We wash our smiling cheeks in peace, a thought for meek devotion.

Tears of Phœbus-missings

Of Cytherea's kissings,

Have in us been found, and wise men find them still ;

Drooping grace unfurls

Still Hyacinthus' curls,

And Narcissus loves himself in the selfish rill;

Thy red lip, Adonis,

Still is wet with morning ;

And the step that bled for thee, the rosy brief adorning.

Oh! true things are fables,

Fit for sagest tables,

And the flowers are true things, yet no fables they ;

Fables were not more

Bright, nor loved of yore-_ \pathway.

Yet thcy grew not, like the flow'rs, by every old

Grossest hand can test us ;

Fools may prize us never-

Yet we rise, and rise, and rise-marvels swect for ever.

Who shall say that flowers

Dress not Heav'n's own bowers?

Who its love, without us, can fancy-or sweet floor?

Who shall even dare

To say we sprang not there,

And came not down that Love might bring one piece of Heaven the morc?

Oh! pray believe that angels

From those blue dominions,

Brought us in their white laps down, 'twixt their golden pinions. 


\section{THE NAR CISS US. BY JOHN KEATS.}

WHAT first inspired a bard of old to sing Narcissus pining o'er the untainted spring? In some delicious ramble he had found A little space, with boughs all woven round; And in the midst of all a clearer pool Than e'er reflected in its pleasant cool The blue sky, here and there serenely peeping, Through tendril wreaths fantastically creeping ; And on the bank a lonely flower he spied, A meek and forlorn flower, with nought of pride, Drooping its beauty o'er the watery clearness, To woo its own sad image into nearness ; Deaf to light Zephyrus it would not move, But still would seem to droop, to pine, to love. So while the poet stood in this sweet spot, Some fainter gleamings o'er his fancy shot; Nor was it long ere he had told the tale Of young Narcissus, and sad Echo's vale.

\section{ON RECEIVING A BRANCH OF MEZEREON,} WHICH FLOWERED AT WOODSTOCK, DEC, I80g.

BY MRS. TIGHE.

ODOURs of spring, my sense ye charm With fragrance premature: And, 'mid these days of dark alarm, Almost to hope allure.

Methinks with purpose soft ye come To tell of brighter hours, Of May's blue skies, abundant bloom, Her sunny gales and showers. 
Alas! for me shall May in vain

The powers of life restore;

These eyes that weep and watch in pain

Shall see her charms no more.

No, no ; this anguish cannot last!

Belovèd friends, adieu!

The bitterness of death were past,

Could I resign but you.

But oh! in every mortal pang

That rends my soul from life-

That soul, which seems on you to hang

Through each convulsive strife,

Even now, with agonising grasp

Of terror and regret,

To all in life its love would clasp,

Clings close and closer yet.

Yet why, immortal, vital spark,

Thus mortally opprest?

Look up, my soul, through prospects dark, And bid thy terrors rest ;

Forget, forego thy earthly part,

Thine heavenly being trust :

Ah! vain attempt ; my coward heart

Still shuddering clings to dust.

O ye who soothe the pangs of death With love's own patient care,

Still, still retain this fleeting breath, Still pour the fervent prayer.

And ye, whose smile must greet my eye

No more, nor voice my ear,

Who breathe for me the tender sigh,

And shed the pitying tear;

D 
Whose kindness (though far, far removed) My grateful thoughts perceive,

Pride of my life, esteemed, beloved, My last sad claim receive!

Oh! do not quite your friend forget, Forget alone her faults ; And speak of her with fond regret Who asks your lingering thoughts.

\section{THE LITTLE RED ROSE.}

\section{FROM GOETHE.}

A BOY caught sight of a Rose in a bowerA little Rose slily hiding

Among the boughs; oh! the Rose was bright And young, and it glimmered like morning light. The urchin sought it with haste ; 'twas a flower

A child indeed might take pride inA little Rose, little Rose, little red Rose, Among the bushes hiding.

The wild boy shouted-" I'll pluck thee, Rose, Little Rose vainly hiding Among the boughs;" but the little Rose spoke"I'll prick thee, and that will prove no joke; Unhurt, oh! then will I mock thy woes, Whilst thou thy folly are chiding." Little Rose, little Rose, little red Rose, Among the bushes hiding!

But the rude boy laid his hands on the flower, The little Rose vainly hiding Among the boughs; oh! the Rose was caught, But it turned again, and pricked and fought, 


\section{The Poetry of Flowers.}

And left with its spoiler a smart from that hour,

A pain for ever abiding :

Little Rose, little Rose, little red Rose,

Among the bushes hiding!

\section{WII.D FLOWERS.}

BY SHELLEY.

I DREAMED that, as I wandered by the way, Bare Winter suddenly was changed to Spring, And gentle odours led my steps astray,

Mixed with a sound of waters murmuring Along a shelving bank of turf, which lay

Under a copse, and hardly dared to fling Its green arms round the bosom of the stream, But kissed it and then fled, as thou might'st in a dream.

There grew pied Wind-flowers and Violets, Daisies, those pearled Arcturi of the earth, The constellated flower that never sets;

Faint Oxlips; tender Blue-bells, at whose birth The sod scarce heaved; and that tall flower that wcts Its mother's face with heaven-collected tears, When the low wind, its playmate's voice, it hears.

And in the warm hedge grew lush Eglantine, Green Cowbind and the moonlight-coloured May, And cherry blossoms, and white cups, whose wine

Was the bright dew yet drained not by the day ; And Wild Roses, and Ivy serpentine,

With its dark buds and leaves, wandering astray, And flowers azure, black, and streaked with gold, Fairer than any wakened eyes behold. 
And nearer to the river's trembling edge

There grew broad flag-flowers, purple prankt with And starry river-buds among the sedge, [white,

And floating Watcr-lilies, broad and bright, Which lit the oak that overhung the hedge

With moonlight beams of their own watery light ; And bulrushes and reeds of such deep grcen As soothed the dazzled eye with sobcr sheen.

Methought that of these visionary flowers

I made a nosegay, bound in such a way That the same hues which in their natural bowers

Were mingied or opposed, the like arrity Kept these imprisoned children of the hours

Within my hand, - and then, elate and gay,

I hastcned to the spot whence I had come, That I might there present it !-Oh! to whom ?

\section{CUPID INSPIRING PLANTS WITH LOVE.}

BY DYER.

Tefming with Nature's lively hues,

I bid thee welcome, genial Spring ; While fancy wakes hor thousand lyres,

And woods and vales rcsponsive sing.

She comes; lo! Winter scowls away;

Harmonious forms start forth to view ;

Nymphs tripping light in circles gay,

Decked in thcir robes of virgin hue.

Then I, on amorous sportings bent,

Like a sly archer take my stand;

Wide through the world my shafts are sent,

And every creature owns my hand. 
First man, the lord of all below, A eaptive sinks beneath my dart; And lovely woman, made to glow, Yields the dominion of her heart.

Through sea, and earth, and boundless sky, The fond subjection all must prove, Whether they swim the stream or fly, Mountain, or vale, or forest rove.

Nor less the garden's sweet domain, The mossy heath or verdant mead, The towering hill, the level plain, And fields with blooming life o'erspread.

\section{THE ALPINE VIOLET.}

BY LORD BYRON.

Trye Spring is eome, the Violet's gone, The first-born ehild of the early sun; With us she is but a winter flower, 'The snow on the hills eannot blast her bower ; And she lifts up her dewy eye of blue, To the youngest sky of the self-same hue.

But when the Spring eomes with her host Of flowers, that flower, beloved the most, Shrinks from the erowd, that may eonfuse Her heavenly odours and virgin hues.

Pluek the others, but still remember, Their herald, out of dire Deeember; The morning star of all the flowers, The pledge of daylight's lengthened hours, And, 'mid the Roses, ne'er forget The virgin, virgin Violet. 


\section{TO A DAISY.}

BY WORDSWOR TH

BRIGHT flower, whose home is everywhere, A pilgrim bold in Nature's care, And oft, the long year through, the heir Of joy or sorrow ;

Methinks that there abides in thee

Some concord with humanity,

Given to no other flower I see

The forest thorough!

And wherefore? Man is soon deprest ;

A thoughtless thing who, onee unblest,

Does litile on his memory rest,

Or on lis reason:

But thou would'st teach him how to find A shelter under every wind;

A hope for times that are unkind, And every season.

\section{THE IVY SONG.}

BY MRS. HEMANS.

Orl ! how could fancy erown with thee

In ancient days the god of wine,

And bid thee at the banquet be

Companion of the vine!

Ivy! thy home is where each sound

Or revelry hath long been o'er,

Where song and beaker once went round,

But now are known no more.

Whcre long-fallen gods recline,

'There the place is thine. 
The Roman on his battle-plains, Where kings before his eagles bent,

With thee, amidst exulting strains,

Shadowed the victor's tent ;

Though shining there in deathless green, Triumphally thy boughs might wave,

Better thou lov'st the silent scene Around the victor's grave.

Urn and sculpture half-divine Yield their place to thine.

The cold halls of the regal dead, Where lone the Italian sunbeams dwell, Where hollow sounds the lightest treadIvy ! they know thee well! And far above the festal vine,

Thou wav'st where once proud banners Where mouldering turrets crest the RhineThe Rhine, still fresh and young !

Tower and rampart o'er the Rhine, Ivy! all are thine!

High from the fields of air look down Those eyries of a vanished racc, Wherc harp, and battle, and renown, Have passed, and left no trace. But thou art there! serenely bright, Mceting the mountain storms with bloom, Thou that wilt climb the loftiest height,

Or crown the lowliest tomb?

Ivy, Ivy $!$ all are thine, Palace, hearth, and shrine.

'Tis still the same; our pilgrim tread $\mathrm{O}^{\prime}$ cr classic plains, through deserts frce, 
On the mute path of ages fled, Still meets deeay and thee.

And still let man his fabries rear, August in beauty, stern in power, Days pass - thou Ivy never sere! And thou shalt have thy dower. All are thine, or must be thine !Temple, pillar, shrine!

\section{DAFFODILS.}

BY WORDSWORTH.

$I$ WANDERED lonely as a eloud

That floats on high o"er vales and hills, When all at onee I saw a erowd, A host of golden Daffodils ; Beside the lake, beneath the trees, Fluttering and daneing in the lreeze.

Continuous as the stars that sline And twinkle in the milky way, They stretched in never-ending line Along the margin of a bay:

Ten thousand saw I at a glanee,

Tossing their heads in sprightly danee.

The waves beside them danced; but they Outdid the sparkling waves in glee:

A poet eould not but be gay, In strels a joeund eompany ;

I gazed and gazed, but little thouglit What wealth the show to me had brought!

For oft when on my eoueh I lie, In vaeant or in pensive mood, 
They flash upon that inward cye Which is the bliss of solitude ; And then my heart with pleasure fills, And dances with the Daffodils.

\section{ADONIS' COUCH.}

\section{BY JOHN KEATS.}

ON a silken couch of rosy pride,

In midst of all, there lay a sleeping youth

Of fondest beauty ; fonder in fair sooth

Than sighs could fathom, or contentinent reach *

And eoverlids gold-tinted like the peach,

Or ripe Oetober's faded Marigolds,

Fell sleek about him in a thousand folds-

Not hiding up an Apollonian eurve

Of neck and shoulder, nor the tending swerve

Of knee from knee, nor ankles pointing light ;

But rather giving them to the filled sight

Officiously. Sideway his face reposed

On one white arm, and tenderly unclosed,

By tend'rest pressure, a faint damask mouth, To slumb'ry pout; just as the morning south Disparts a dew-lipped rose. Above his head Four lily stalks did their wide honours wed To make a eoronet ; and round him grew All tendrils green, of every bloom and hue, Together intertivined and trammelled fresh : The vine of glossy sprout ; the ivy mesh. Shading its Ethiop berries; and woodbinc, Of velvet leaves and bugle blooms divine; Convolvulus in streakéd vases flush ; The ureeper, mellowing for an autumn blush 
And virgin's-bower, trailing airily,

With others of the sisterhood. Hard by,

Stood serene Cupids watehing silently.

One, kneeling to a lyre, touehed the strings,

Muffing to death the pathos with his wings ;

And, ever and anon, uprose to look

At the youth's slumber; while another took

A willow bough, distilling odorous dew,

And shook it on his hair ; another flew

In through the woven roof, and fluttering wise,

Rained Violets upon his sleeping eyes.

\section{SONNET.}

\section{B Y S P E N S E R.}

SWEET is the rose, but growes upon a brere ;

Sweet is the Juniper, but sharpe his bough ; Sweet is the Eglantine, but prieketh nere;

Sweet is the Firbloom, but his branehes rough;

Sweet is the Cypress, but his rind is tough,

Sweet is the Nut, but bitter is his pill ;

Sweet is the Broome-flowere, but yet sowre enough;

And sweet is Moly, but his roote is ill.

So every sweet with sowre is tempred still,

That maketh it be eoveted the more:

For easie things that may be got at will,

Most sorts of men doe set but little store.

Why then should I aeeount of little pain,

That endless pleasure shall unto me gaine?

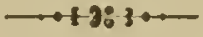




\section{THE F LOWER-DIAL.}

BY MRS. HEMANS.

'TWAS a lovely thought to mark the hours, As they floated in light away, By the opening and the folding flowers, That laugh to the summer's day.

Thus had each moment its own rich hue, And its graceful cup and bell,

In whose coloured vase might slcep the dew, Like a pearl in an ocean shcll.

To such sweet signs might the time havc flowed In a golden current on,

Ere from the garden, man's first abode, The glorious guests were gone.

So might the days have been brightly toldThose days of song and drcams-When shepherds gathered their flocks of old, By the blue Arcadian streams.

So in those islcs of delight, that rest Far off in a breezeless main, Which many a bark, with a weary quest, Has sought, but still in vain.

Yet is not life, in its real flight, Marked thus-even thus-on earth, By the closing of one hope's dclight, And another's gentle birth?

Oh! let us live so that flower by flower, Shutting in turn, may leave

A lingcrer still for the sunset hour, A charm for the shaded eve. 


\section{SPRING FLOWERS.} BY SHAKESPEARE.

That come before the swallow dares, and talke The winds of Mareh with beauty; Violets dim, But sweeter than the lids of Juno's eyes, Or Cytherea's breath; pale Primroses, That die unmarried, ere they ean belold Bright Phœbus in his strength ;

Bold Oxlips, and
The erown imperial ; Lilies of all kinds,

The flower-de-luee being one.

\section{BOWING ADORERS.}

\section{BY CLARE.}

Bowing adorers of the gale, Ye Cowslips delicately pale, Upraise your loaded stems ; Unfold your eups in splendour; speak ! Who decked you with that ruddy streak, And gilt your golden gems?

Violets, sweet tenants of the shar?e, In purple's richest pride arrayed, Your errand liere fulfil ;

Go, bid the artist's simple strain Your lustre imitate in vain, And mateh your Maker's skil!.

Daisies, ye flowers of lowly birtin, Embroid'rers of the earpet earth, That stud the velvet sod; Open to Spring's refreshing air, In sweetest smiling bloom deelare Your Maker, and my God. 


\section{F R A G M N T. \\ BY COWPER.}

SOME clothe the soil that feeds them, far diffused And lowly creeping, modest and yet fair, Like virtue, thriving most where little seen ; Some, more aspiring, catch the neighbour shrub With clasping tendrils, and invest his branch, Else unadorned, with many a gay festoon And fragrant chaplet, recompensing well The strength they borrow with the grace theylend.

\section{TO A MOUNTAIN DAISY,}

ON TURNING ONE DOIVN IVITH THE PLOUGH.

BY BURNS.

WEE, modest, crimson-tippéd flower,

Thou'st met mc in an evil hour ;

For I maun crush among the stour

Thy slender stem ;

To spare thee now is past my power,

Thou bonnie gem.

Alas! it's no thy neebour sweet, The bounie lark, companion meet, Bending thee 'mang the dewy weet, Wi' speckled breast,

When upward springing, blithe, to greet

The purplin' east.

Cauld blew the bitter biting north

Upon thy early, humble birth :

Yet checrfully thou glinted forth

Amid the storm, 
Scarce reared above the parent earth

Thy tender form.

The flaunting flowers our gardens yield,

High sheltering woods and wa's maun shield;

But thou, beneath the random bield

$\mathrm{O}^{\prime}$ clod or stane,

Adorns the histie stibble-field,

Unseen, alane.

There, in thy scanty mantle clad,

Thy snowy bosom sunward spread,

Thou lifts thy unassuming head

In humble guise ;

But now the share uptears thy bed,

And low thou lies!

Such is the fate of artless maid, Sweet flow'ret of the rural shade!

By love's simplicity betrayed,

And guileless trust ;

Till she, like thee, all soiled, is laid

Low i' the dust.

Such is the fate of simple bard,

On life's rough ocean, luckless starred !

Unskilful he to note the card

Of pruclent lore,

Till billows rage, and gales blow hard,

And whelm him o'er !

Such fate to suffering worth is given,

Who long with wants and woes has striven,

By humail pride or cunning driven

'To misery's brink,

Till, wrenched of every stay but Heaven,

He ruined sink ! 
E'en thou who mourn'st the Daisy's fate,

That fate is thine-no distant date ;

Stern Ruin's ploughshare drives elate,

Full on thy bloom,

Till crushed beneath the furrow's weight

Shall be thy doom.

\section{THE BROKEN FLOWER.}

\section{BY MRS. HEMANS.}

$\mathrm{OH} !$ wear it on thy heart, my love, Still, still a little while ;

Sweetness is lingering in its leaves,

Though faded be their smile.

Yet for the sake of what hath been,

Oh! cast it not away ;

'Twas born to grace a summer scene,

A long, bright, golden day !

My love,

A long, bright, golden day!

A little while around thee, love, Its fragrance yet shall cling, Telling that on thy heart hath lain

A fair, though faded thing.

But not even that warm heart hath power

To win it back from fate :-

Oh ! I am like thy broken flower,

Cherished too late, too late,

Cherished, alas! too late.

$$
\text { My love, }
$$




\section{THE ROSE AND THE GAUNTLET. BY JOHN STERLING.}

Low spake the Knight to the peasant gir\}. "I tell thee sooth-I am belted Earl; Fly with me from this garden small, And thou shall sit in my castle's hall. "Thou shalt have pomp, and wealth, and pleasure, Joys beyond thy fancy's measure ; Here with my sword and horse I stand, To bear thee away to my distant land. "Take, thou fairest, this full-blown Rose, A token of love that as ripely blows." With his glove of steel he plucked the token, But it fell from his gauntlet crushed and broken. The maiden exclaimed- "Thou seest, Sir Knight, Thy fingers of iron can only smite ; And, like the Rose thou hast torn and scattered, I in thy grasp should be wrecked and shattered." She trembled and blushed, and her glances fell ;

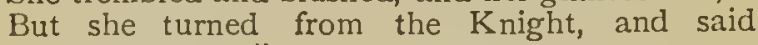
"Farewell!"

"Not so," he cried, "will I lose my prize ; I heed not thy words, but I read thine eyes."

He lifted her up in his grasp of steel, And he mounted and spurred with furious heel; But her cry drew forth her hoary sire, Who snatched his bow from above the fire.

Swift from the valley the warrior fled, Swifter the bolt of the cross-bow sped; And the weight that pressed on the fleet-foot horse, Was the living man, and the woman's corse. 


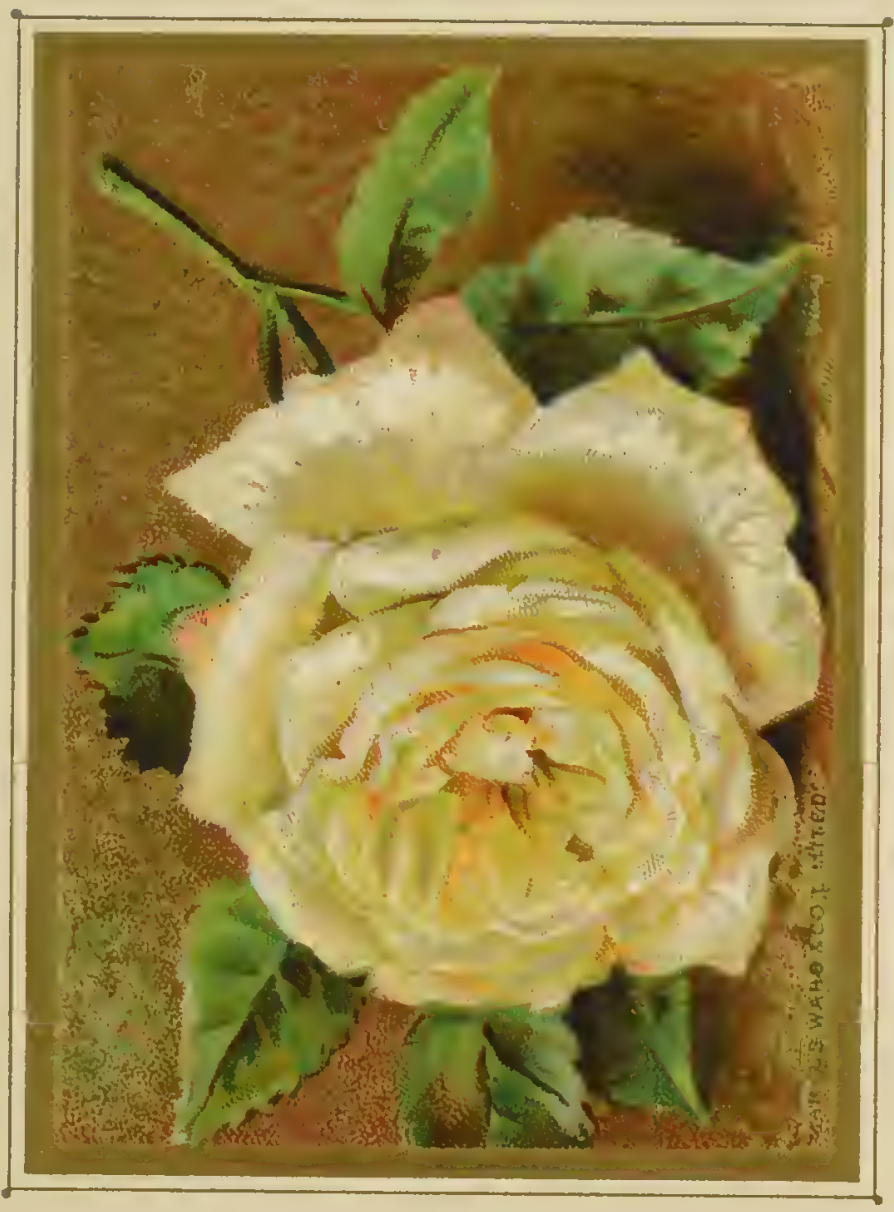





\section{The Poetry of Flowers.}

That morning the Rose was bright of hue :

That morning the maiden was fair to view:

But evening sun its beauty shed

On the withered leaves, and the maiden dead.

\section{THE ROSE. \\ BY WALLER,}

Go, lovely Rose!

Tell her that wastes her time on me,

That now she knows,

When I resemble her to thee,

How sweet and fair she seems to be.

Tell her that's young,

And shuns to have her graces spied,

That hadst thou sprung

In deserts where no men abide,

Thou inust have uneommended died.

Small is the worth

Of beauty from the light retired;

Bid her eome forth,

Suffer herself to be desired,

And not blush so to be admired.

Then die, that she

The common fate of all things rare

May read in thee;

How small a part of time they share

That are so wondrous sweet and fair.

Yet, though thou fade,

From thy dead leaves let fragranee rise ;

And teaeh the maid

That goodness Time's rude hand defies ;

That virtue lives when beauty dies.

E 


\section{HEAR'T'S-EASE.}

I USED to love thee, simple flowerTo love thee deariy when a boy ; For thou didst seem in childhood's hour The smiling type of ehildhood's joy.

But now thou only work'st my grief, By waking thoughts of pleasures fled.

Give me-give me the withered leaf, That falls on Autumn's bosom dead. For that ne'er tells of what has been, But warns me what I soon shall be ; It looks not baek on pleasure's seene, But points unto futurity.

I love thee not, thou simple flower, For thou art gay, and 1 am lone ; 'Thy beauty died with elildhood's hour--'The Heart's-ease from my path is gone.

THE MOSS-ROSE. BY JOHN STERLING. Mossy Rose on mossy stone, Flowering 'mid the ruins lone, I have learnt, beholding thee, Youth and Age may well agree.

Baby germ of freshest hue, Out of ruin issuing new ; Moss a long laborious growth, And one stalk supporting both. Thus may still, while fades the past, Life come forth again as fast ; Happy if the relies sere Deck a cradle, not a bier. 
Tear the garb, the spirit flies, And the heart, unsheltered, dies;

Kill within the nursling flower, Scarce the green survives an hour.

Ever thus together live, And to man a lesson give : Moss, the work of vanished years; Rose, that but to-day appears.

Moss, that covers dateless tombs; Bud with early siveet that blooms; Childhood thus, in happy rest, Lies on aneient Wisdom's breast.

Moss and Rose, and Age and Youth, Flush and Verdure, Hope and Truth, Yours be peace that knows not strife, One the root and one the life.

\section{THE H Y A I N TH. bY CASIMIR.}

CHILD of the Spring, thou eharming flower, No longer in confinement lie, Arise to light, thy form diseover, Rival the azure of the sky.

The rains are gone, the storms are o'er; Winter retires to make thee way;

Come then, thou sweetly blooming flower, Come, lovely stranger, come away.

The sun is dressed in beaming smiles, To give thy beauties to the day: Young zephyrs wait with gentlest gales, To fan thy bosom as they play. 


\section{TIE QUEEN OF THE GARDEN.}

BY MOORE.

IF Jove would give the leafy bowers

A queen for all their world of flowers, The Rose would be the choice of Jove, And reign the queen of every grove. Sweetest child of weeping morning, Gem the vest of earth adorning, Eye of flow'rets, glow of lawns, Bud of beauty, nursed by dawns ; Soft the soul of love it breathes, Cypria's brow with magic wreathes, And to the zephyr's warm caresses Diffuses all its verdant tresses, Till, glowing with the wanton's play, It blushes a diviner ray !

\section{THE COWSLIP.}

UNFOLDING to the breeze of May, The Cowslip greets the vernal ray, The topaz and the ruby gem, Her blossom's simple diadem ; And, as the dew-drops gently fall, They tip with pearls her coronal. In princely halls and courts of kings Its lustrous ray the diamond flings; Yet few of those who see its beam, Amid the torch-light's dazzling gleam, As bright as though a meteor shone, Can call the costly prize their own. But gems of every form and hue Are glittering here in morning dew ; 
Jewels that all alike may share

As freelyas the common air ;

No niggard hand, or jealous eye,

Protects them from the passer by.

Man to his brother shuts his heart,

And Science acts a miser's part ;

But Nature, with a liberal hand,

Flings wide her stores o'er sca and land.

If gold she gives, not single grains

Are seattered far across the plains :

But, lo! the desert streams are rolled

O'er precious beds of virgin gold.

If flowers she offers, wreaths ale given,

As eountless as the stars of heaven;

Or music-'tis no feeble note

She bids along the valleys float ;

Ten thousand nameless melodies

In one full chorus swell the breeze.

Oh! Art is but a scanty rill

That genial seasons scarcely fill;

But Nature needs no tide's return

'To fill afresh her flowing urn :

She gathers all her rich supplies

Where never-failing waters rise.

TO THE ROUND-LEAFED SUNDEW.

BY the lone fountain's secret bed,

Where human footsteps rarely tread,

'Mid the wild moor of silent glen,

The Sundew blooms unseen by men ,

Spreads there her leaf of rosy hue,

A elalice for the morning dew,

And, ere the summer's sun can rise,

Urinks the pure waters of the skies. 
Would'st thou that thy lot werc given Thus to receive the dews of heaven, With heart prepared, like this meek fiower? Come, then, and hail the dawning hour; So shall a blessing from on high, Pure as the rain of summer's sky,

Unsullied as the morning dew, Descend, and all thy soul imbue.

Yes! like the blossoms of the waste Would we the sky-born watcrs taste, To the High Fountain's sacred spring The chalicc lct us humbly bring : So shall we find the streams of hoaven To him who secks are frecly given ; The morning and the evening dcw Shall still our failing strength rencw.

\section{A CYPRESS LEAF :}

FOR THE GRAVE OF A DEAR ONE.

THE fcelings I have felt have died away,

'The love that was my lamp death's dcws have quenched ;

The faith which, through life's ills, nc'er knew dccay,

Hath in the chill showers of the grave bccn drenched;

The hopes that buoyed my spirit 'mid the spray Of life's wild ocean, one by onc are wrenched Cruelly wrenched away, - and I a m now A solitary leaf on a rent. bough!

The link that knit me to mankind is snappedBriefly it bound me to a callous world; The fortress of my comfort hath been sappedWhere are Joy's banners, lightsomely unfurlew 


\section{The Poetry of Flowers.}

That graced the battlements? In vapour wrappcd, In the dense smoke of stifled breath upcurled, They drop in tatters, forming now a pall For the sad mummy-heart that drips with gall.

I have not now of broken troth to wail, I have not now to speak of friendship broken; Of Death and Death's wild triumphs is my taleOf friendship faithful, and of love's last token, A ring ! - whose holy motto ne'er shall fail To rouse such sorrow as may ne'er bc spoken : That pictured Dove and Branch-those words "La Paix!"

(O direful moekery !) wear my heart away!* "Peace?"-Peace! alas, there is no peace for me. It rcsts with thee, belov'd one, in the grave! Yet, when I search the cells of Memory, Where silently the subterranean wave Of buried hope glides on, a thought of theeLike sunshine on the hermit's darkened caveSteals gently o'er my spirit, whispering swect Of realms beyond the tomb, where we shall meet!

Our love-how did it spring? In sooth it grew,

Even as some rare exotic in a clime Unfriendly to its growth: yet rich in hue, Voluptuous in fragrance, as if Time Had been to it all sunlight and soft dew, As if upon its freshness the cold rime Of dcath should never fall! How came it, then? Even as the manna fell 'midst famished men,

* A melancholy anerdote is attached to these lines: the motto "LA PAIX" was engraved on the bequeathed gift of a beloved friend, who, in the bloom of youth, fell a victim to a sudden and violent death in India. 
To be snatched up in transport! And we fed Upon affeetion's banquet, that ne'er palled Upon the spirit's palate! Friendship shed A light around our bosoms, whieh reealled The memory of that bard whose soul was wedWith love surpassing woman's love, ungalled By selfish doubts-to him, the monareh's son, Brave Jonathan! Like theirs, our souls were one. Oh! long we loved in silenee! Neither spake Of that which worked the thoughtful mine within; Thou didst not guess that, sleeping or awake, My thoughts were full of thee till thought grew For it is sin of earthly things to make

Our idols; and I never hoped to win Thy coveted affeetion; but for me, Thy heart was also yearning silently!

I was the first to speak-and words there were, Wild words, that painted fond affeetion's eourse ; Oh ! what indeed will erring tongues not dare, When eonquering Feeling prompts! Like winds that foree

From wind-harps mystie sounds, the lips deelare Thoughts that are often followed by remorse ; For passion hath a poteney that breaks Each puny bulwark eallous Reason makes!

But ours was Friendship's purest worship-pure, Altho' that worship bowed at earthly shrines ; Alas! that hearts on altars inseeure Should saerifiee their all of bliss! There twines

O'er mankind's sweetest hopes eorruption sure, To blast their beauty e'en whilst most it shines! 'Tis but to teach us there are worlds above, Where Hope fruition finds in endless Love ! 


\section{WILD FLOWERS.}

BY JOHN KEATS.

I STOOD tiptoe upon a littlc hill;

The air was cooling, and so very still, That the sweet buds which, with a modest pride, Fell drcopingly in slanting curve aside, Their sci nty-lcaved and finely tapering stems Had not je. lost their starry diadems, Caught from the early sobbings of the morn.

The clouds were pure and white as flocks new shorn, And frcsh from the clear brook; sweetly thcy slcpt On the blue fields of heaven, and then there crept A little noiseless noise among the leaves, Born of the very sigh that silence haves; For not the faintest motion could be seen Of all the shades that slanted o'er the green. There was wide wandering for the grecdiest eye, To peer about upon variety;

Far round the horizon's crystal air to skim, And trace the dwindled edgings of its brim ; To picture out the quaint and curious bending Of a fresh woodland alley never-cnding ; Or by the bowery clefts and leafy shelves, Guess wherc the jaunty streams refresh themselves. I gazed awhile, and felt as light and free As though the fanning wings of Mercury Had played upon my heels: I was light-hearted, And many plcasurcs to my vision started; So I straightway began to pluck a posy Of luxuries bright, nilky, soft, and rosy. A bush of May-flowers with the bees about them; Ah! sure no tasteful nook could be without them; And let a lush laburnum overswecp them, 
And let long grass grow round the roots, to keep them Moist, cool, and green; and shade the violets, That they may bind the moss in leafy nets. A filbert edge, with wild-brier overtwined, And clumps of woodbine taking the soft wind Upon their summer thrones; there, too, should be The frequent chequer of a youngling tree,

That with a score of bright-green brethren shoots From the quaint mossiness of aged roots : Round which is heard a spring-head of clear waters, Prat tling so wildly of its lovely daughters, The spreading blue-bells : it may haply mourn That such fair clusters should be rudely torn From their fresh beds, and scattered thoughtlessly By infant hands left on the path to die. Open afresh your round of starry folds, Ye ardent marigolds !

Dry up the moisture from your golden lids, For great Apollo bids

That in these days your praises should be sung On many harps, which he has lately strung ; And when again your dewiness he kisses, Tell him I have you in my world of blisses: So, haply, when I rove in some far valc, His voice may come upon the gale.

Here are sweet-peas, on tiptoe for a flight, With wings of gentle flush o'er delicate white, And taper fingers catching at all things, To bind them all about with tiny rings. What next? a turf of evening primroses, O'er which the mind may hover till it dozes; O'er which it wcll might take a pleasant slecp, But that 'tis ever startled by the leap Of buds into ripe flowcrs. 


\section{THE JASMINE. \\ BY MOORE.}

'TwAs midnight-through the lattiee wreathed

With Woodbine, many a perfume breathed

From plants that wake when others sleep ;

From timid Jasmine buds that keep

Their odour to themselves all day;

But when the sunlight dies away,

Let the delieious secret out

To every breeze that roams about.

\section{$\longrightarrow$ \\ TO PRIMROSES}

FILLED IVITH MORNING DEW.

BY HERRICK.

Why do ye weep, sweet babes? Can tears

Speak grief in you,

Who were but born

Just as the modest morn
Teemed her refreshing dew?

Alas! ye have not known that shower

That mars a flower ;

Nor felt the unkind

Breath of a blasting wind ;

Nor are ye worn with years;

Or warped as we,

Who think it strange to see

Such pretty flowers, like to orphans young,

Speaking by tears before ye have a tongue.

Speak, whimpering younglings, and make known

The reason why

Ye droop and weep. 
Is it for want of sleep,

Or ehildish lullaby?

Or that ye have not seen as yet

'The violet?

Or brought a kiss

From that sweetheart to this?

No, no; this sorrow shown

By your tears shed,

Would have this leeture read:

That things of greatest, so of meanest worth, Coneeived with grief are, and with tears brought forth.

\section{THE DAISY.}

BY JOHN MASON GOOD.

Not worlds on worlds, in phalanx deep,

Need we to prove that God is here; The Daisy, fresh from Winter's sleep,

Tells of His hand in lines as elear.

For who but He who arehed the skies,

And poured the day-spring's living flood,

Wondrous alike in all He tries,

Could rear the Daisy's purple bud ;

Mould its green eup, its wiry stem, Its fringéd border nieely spin, And cut the gold-embosséd gem That, set in silver, gleams within ;

And fling it unrestrained and free,

O'er hill and dale, and desert sod,

That man, where'er he walks, may see,

At every step, the stamp of God? 


\section{FROM METASTASIO.}

The married are compared by the poet to the young Rose, which the lover places in the bosom of his mistress, first stripped of thorns.

THOU virgin Rose! whose opening leaves so fair,

The dawn has nourished with her balmy dews, While softest whispers of the morning air

Called forth the blushcs of thy vermeil hues ; That cautious hand, which cropt thy yout hful pride, Transplants thy honours, where from hurt secure, Stript of each thorn offensive to thy side,

Thy nobler part alone shall bloom mature.

Thus thou, a flower, exempt from change of skies, By storms and torrents unassailed sliall r.se, And scorn the winter colds and summer heats ; A guard more faithful then thy growth shall tend, By whom thou may'st in tranquil union blend Eternal beauties with eternal sweets.

\section{THE NARCISSUS.}

BY GAY.

IIERE young Narcissus o'er the fountain stood, And viewed his image in the crystal flood; The crystal flood reflects his lovely charms, And the pleascd image strives to meet his arms. No nymph his inexpcrienced breast subdued, Echo in vain the flying boy pursued. Himself alone the foolish youth admires, And with fond look the smiling shade desires; O'er the smooth lake with fruitless tears he grieves; IHis spreading fingcrs shoot in vcrdant leaves; 
Through his pale veins green sap now gently flows, And in a short-lived flower his beauty blows. I et vain Narcissus warn each female brcast, That beauty's but a transient good at best ; Like flowers it withers with the advancing year, And age, like winter, robs the blooming fair.

\title{
A SONG OF THE ROSE.
}

\author{
BY MRS. HEMANS.
}

ROSE ! what clost thou here?

Bridal, royal Rose!

How, 'midst grief and fear,

Canst thou thus disclose

That fervid hue of love which to thy heart-leaf glows?

Rose! too much arrayed

For triumphal hours,

Look'st thou through the shade

Of these mortal bowcrs,

Not to disturb my soul, thou crowned one of all flowers!

As an eagle soaring

Through a sunny sky,

As a clarion pouring

Notes of victory,

So dost thou kindle thoughts, for earthly life too high -

Thouglits of rapture flushing

Youthful poet's cheek,

Thoughts of glory rushing

Forth in song to break,

But finding the spring-tide of rapid song too weak. 


\section{Yet, oh! festal Rose,}

I have seen thee lying

In thy bright repose

Pillowed with the dying,

Thy crimson by the life's quick blood was flying.

Summer, hope, and love,

O'er that bed of pain,

Meet in thee, yet wove

Too, too frail a claim

In its embracing links the lovely to detain.

Smil'st thou, gorgeous flower?-

Oh! within the spells

Of thy beauty's power

Something dimly divells,

At variance with a world of sorrows and farewells.

All the soul forth flowing

In that rich perfume,

All the proud life glowing

In that radiant bloom,

Have they no place but here, beneath the o'ershadowing tomb?

Crown'st thou but the daughters

Of our tearful race?-

Heaven's own purest waters

Well might bear the trace

of thy consummate form, melting to softer grace.

Will that clime enfold thee

With immortal air?

Shall we not behold thee

Bright and deatlless there?

In spirit-lustre clothed, transcendently inore fair? 
Yes! my fancy sces thee

In that light disclose,

And its dream thus frees thee

From the mist of woes,

Darkening thine earthly bowers, O bridal, royal

Rose!

\section{TH E ROS E.}

FROM BEAUMONT AND FLETCHER.

Methinks a Rose is best

OF all flowers,

It is the very emblem of a maid;

For when the west winds court her gently,

How modestly she blows, and paints the sun

With her chaste blushes! When the north comes near her,

Rude and impatient, then, like chastity, She locks her beauties in her bud again, And leaves him to base briers.

\section{TIE CAPTIVE AND THE FLOWERS.}

FROM THE GERMAN OE GOETHE.

CAPTIVE.

A FLOWER that's wondrous fair, I know,

My bosom holds it dear ;

To seek that flower I long to go,

But am imprisoned here.

'Tis no light grief oppresses me ; For in the days my steps were free,

I had it always near. 
Far round the tower I send mine cye,

The tower so steep and tall;

But nowhere can tlie flower descry

From this high castle wall ;

And him who'll bring me my desire,

Or be he knight, or be he squire,

My dearest friend I'll call.

\section{ROSE.}

My blossoms near thee I disclose, And hear thy wretched plight ;

Thou meanest me, no doubt, the Rose,

Thou noble, hapless knight.

A lofty mind in thee is seen,

And in thy bosom reigns the queen

Of flowers, as is her right.

\section{CAPTIVE.}

Thy crimson bud I duly prize In outer robe of green ;

For this thou'rt dear in maiden's eycs,

As gold and jewels' sheen.

Thy wreath adorns the fairest brow,

And yet the flower-'tis not thou

Whom my still wishes mean.

\section{LILY.}

The little Rose has cause for pride,

And upwards aye will soar ;

Yet am I held by many a biide

The Rose's wreath before.

And beats thy bosom faithfully, And art thou true, and pure as $I$,

Thou'lt prize the Lily more. 
CAPTIVE.

I call myself both chaste and pure, And pure from passions low ;

Aidd yet these walis my limbs immure

In loneliness and woe.

Though thou dost seem, in white array, Like many a pure and beauteous maid, One dearer thing I know.

\section{PINK.}

And dearer I, the Pink, must be, And me thou sure dost choose, Or clse the gard'ner ne'er for me Such watchful care would use ; A crowd of leaves enriching bloom! And mine through life the sweet perfume, And all the thousand hues.

\section{CAPTIVE.}

The Pink can no one justly slight, The gard'ner's favourite flower; Ife sets it now beneath the light,

Now shields it from its power. Yet 'tis not pomp, who o'er this rest In splendour shines, can make me blest ;

It is a still, small flower.

\section{VIOLET.}

I stand concealed, and bending low,

And do not love to speak ; Yet will I, as 'tis fitting now,

My wonted silence brealk.

For if 'tis I, thou gallant man, Thy heart dcsires, thine, if I can, My perfumes all I'll make. 


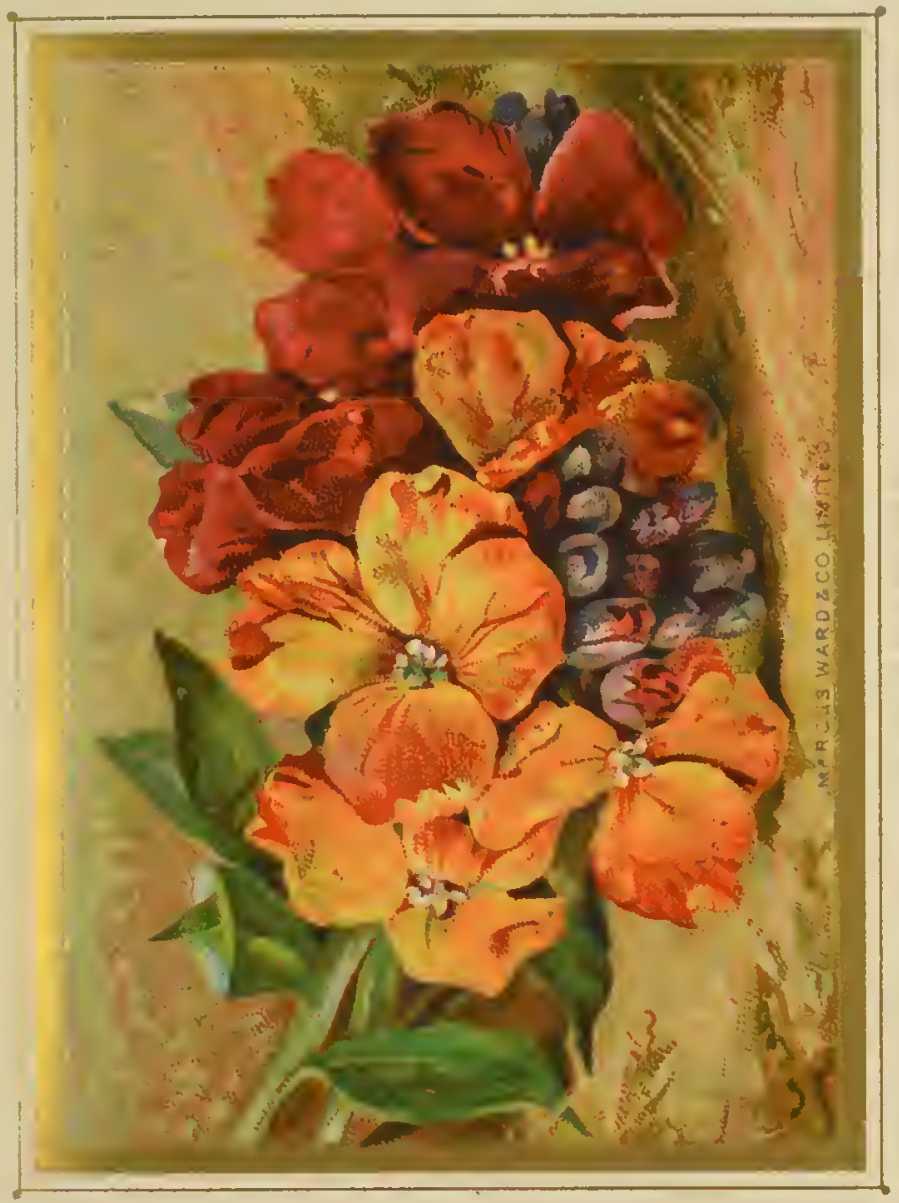



CAPTIVE.

The Violet I esteem indeed, So modest and so kind; Its fragrance sweet yet more I need, To soothe mine anguished mind. To you the truth will I confess ; Here, mid this roeky dreariness, My love I ne'er shall find. The truest wife by yonder brook Will roam the mournful day, And hither east the anxious look, Long as immured I stay. Whene'er she breaks a small blue flower, And says, "Forget me not!" the power I feel, though far away. Yes, e'en though far, I feel its might, For true love joins us twain, And therefore 'mid the dungeon's night

I still in life remain. And sinks my heart at iny hard lot, I but exclaim, "Forget me not I" And straight new life regain.

\section{FRAGMENT.}

BY SIR WALTER SCOTT.

AND well the lonely infant knew Reeesses where the Wallflower grew, And Honeysuekle loved to erawl Up the low crag and ruined wall. I deemed such nooks the sweetest shade The sun in all his round surveyed, And still I thought that shattered tower The mightiest work of human power. 


\section{SEND THE LILIES GIVEN TO ME.} BY BYRON.

I SEND the Lilies given to me,

Though, long before thy hand they touch,

I know that they must withered be ;

But yet reject them not as such:

For I have cherished them as dear,

Because they yet may meet thine eye, And guide thy soul to mine even here,

When thou behold'st them drooping nigh, And know'st them gathered by the Rhine, And offered from my heart to thine!

The river nobly foams and flows,

'The charm of this enchanted ground, And all its thousand turns disclose

Some fresher beauty varying round; The haughtiest breast its wish might bound, Through life to dwell delighted here; Nor could on earth a spot be found

To nature and to me so dear. Could thy dear eyes; in following mine, Still sweeten more these banks of Rhine !

\section{THE FURZE.}

'MiD scattered foliage, pale and sere, Thy kind flow'ret cheers the gloom ; And offers to the waning year

'The tribute of its golden bloom.

'Neath November's clouded sky, In chill Deccmber's stormy hours, 
Thy blossom meets the traveller's eye, Gay as the buds of summer bowcrs.

Flower of the dark and wintry day!

Emblem of friendship! thee I hail!

Blooming when others fade away, And brightest when their hues grow pale.

\section{TO DAFFODILS.}

BY ROBERT HER I CK.

FAIR Daffodils, we weep to see

You haste away so soon ;

As yet, the early-rising sun

Has not attained its noon.

Sitay, stay,

Until the hastening day

Has run

But to the even song ;

And having prayed together, we

Will go with you along.

We have short time to stay as you,

We have as short a spring ;

As quick a growth to meet decay,

As yout or any thing.

We die,

As your hours do, and dry Away,

Like to the summer's rain, Or as the pearls of mornirg's dew,

Ne'er to be found again. 


\section{TO THE PRIMROSE. \\ BY BIDLAKE.}

PALE visitant of balmy Spring,

Joy of the new-born year,

That bidd'st young Hope new-plume his wing,

Soon as thy budls appenr:

While o'er the incense-breathing sky

The tepid hours first dare to fly,

And vainly woo the chilling brceze

That, bred in Winter's frozen lap,

Still struggling chains the lingering sap

Within the widowed trees.

Remote from towns, thy transient life

Is spent in skies more pure;

The suburb smoke, the seat of strife,

Thou canst but ill endure.

Coy rustic! thou art blooming found

Where artless Nature's charms abound,

Sweet neighbour of the chanter rill ;

Well pleased to sip the silvery ticle,

Or nodding o'er the fountain's side, Self-gazing, look thy fill;

Or, on the dingle's shadowy steep,

'The gaudy Furze beneath,

Thy modest beauties sweetly peep,

Thy chaster odours breathe.

From luxury we turn aside,

From wealth and ostentatious pride,

With many an emblematic thorn,

Thy humbler mien well pleased to ineet;

Like competence in blest retreat,

Thy smiles the Spring adorn. 
What though thou boast no splendid hue

Of Flora's prouder race?

To me more fair art thou to view,

In all thy simplc grace:

Thiue innocence and beauty meek,

More like my Celestina's cheek,

Where all the modest virtues play;

Expression beaming from hor eye,

In cherub smiles of chastity,

With inild and tempered ray.

Yct treasures lurk within thy lips,

To glad the spoiler bee,

Who not with idle errand sips,

Or wanton vagrancy.

Ah! blest is he who temperance tries,

Simplicity above disguise,

And shuns the falser gloss of art ;

'Tis he extracts a bliss refined,

Congenial to the virtuous mind,

The tender feeling heart.

Thy smiles young innocence invite,

What time thy lids awake,

In shadowy lane to taste delight,

Or mazy, tangled brake.

The infant troop of rosy hue,

And gay with health, I seem to view,

While pleasure lights their laughing eyes;

With little hands a wreath combine,

Their fugitive delights entwine,

And boast their fragrant prize.

Aln! happy breasts ! unknown to pain,

I would not spoil your joys; 
Nor vainly teach you to complain

Of life s delusive toys.

Be iocund still, still sport and smile,

Nor dream of woe or future guile;

For soon shall ye, awakened, find

The joys of life's sad thorny way

But fading flow'rets of a day,

Cut down by every wind.

\section{FADED FLOWERS.}

BY MISS JEWSBURY.

FADED flowers,

Sweet faded flowers,

Beauty and death

Have ruled your hours.

Ye woke in bloom but a morn ago,

And now are your blossoms in dust laid low.

But yesterday,

With the breeze ye strove-

In the play of life,

In the pride of love ;

To and fro swung each radiant head,

That now is drooping, and pale, and dead!

Delicate flower,

With the pearl-white bells,

No more shall dew-drop

Sleep in thy cells !

No more, rich Rose, on thy heaving breast,

The lioney-bee fold his wings to rest ! 
Fair myrtle tree,

'Thy blossoms lie low,

But green above them

Thy branehes grow ;

Like a buried love, or a vanished joy,

Linked into memories none destroy.

Faded flowers,

Sweet faded flowers!-

Fair frail reeords

Of Eden's bowers ;

In a world where sorrow and wrong bear sway, Why should ye linger?-away! away!-

What were the emblems

Pride to stain,

Might ye your glorious

Crowns retain?

And what for the young heart, bowed with grief, Were the Rose ne' er seen with a withered leal!

Ye bloom to tell us

What onee hath been ;

What yet shall in heaven

Again be seen ;

Ye die, that man in his strength may learn

How vain the hopes in his heart that burn.

Many in form,

And bright in hue!

I know your fate-

But the earth to strew-

And my soul flies on to immortal bowers, [flowers Where the heart and the Rose are not faded 


\section{THE ROSES.}

\section{BY BOWRING.}

I SAW them once blowing,

While morning was glowing;

But now are their withered leaves strewed o'er the ground,

For tempests to play on,

For cold worms to prey on,

The shame of the garden that triumphs around.

Their buds which then flourished,

With dew-drops were nourished,

Which turned into pearls as they fell from on higrh :

Their hues are all banished,

Their fragrance all vanished,

Ere evening a shadow has cast from the sky.

I saw, too, whole raees

Of glories and graces

Thus open and blossom, but quickly deeay ;

And sniling and gladness,

In sorrow and sadness,

Ere life reached its twilight, fade dimly away.

Joy's light-hearted dances,

And melody's glances,

Are rays of a moment-are dying when born;

And pleasure's best dower

Is nought but a flowcr,

$A$ vanishing dew-drop-a gem of the morn.

The bright eye is clouded,

Its brilliancy shroudcd,

Our strength disappears, we are hclpless and lonc;

No reason avails us,

And intellect fails us ;

Life's spirit is wasted, and darkness comes on. 


\section{TO THE SNOWDROP.} BY BARRY CORNWALL.

PrETTY firstling of the year!

Herald of the host of flowcrs! Hast thou left thy cavern drear,

In the hope of summer hours?

Back unto thy earthen bowers, Back to thy warm world below,

Till the strength of suns and showers Quell the now relentless snow!

\section{Art still here?-Alive? and blithe?}

Though the stormy night hath flcd, And the Frost hath passed his scythe

O'er thy small unsheltered head?

$\mathrm{Ah} !$ some lie amid the dead

(Many a giant stubborn tree,-

Many a plant, its spirits shed),

That were bctter nursed than thee!

What hath saved thee? Thou wast not

'Gainst the arrowy winter furredArmed in scale-but all forgot

When the frozen winds were stirred.

Nature, who doth clothe the bird, Should have hid thee in the earth,

Till the cuckoo's song was heard, And the Spring let loose her mirth.

Nature-deep and mystic word,

Mighty mother! still unknown; Thou didst sure the Snowdrop gird

With an armour all thy own! 
Thou, who send'st it forth alone To the eold and sullen season

(Like a thought at random thrown),

Sent it thus for some grave reason 1

If 'twere but to pieree the mind

With a single gentle thought, Who shall deem thee harsh or blind?

Who that thou hast vainly wrought?

Hoard the gentle virtue eaught

From the Snowdrop-reader wise!

Good is good, wherever taught,

On the ground or in the skies!

\section{TO THE JESSAM I NE. BY MISS JANE TAYLOR.}

'WWE'T Jessamine! long may thy elegant flower

Breathe fragrance and solace for me!

And long thy green sprigs overshadow the bower

Devoted to friendship and thee.

The eye that was dazzled where I.ilies and Roses

Their brilliant assemblage displayed, With grateful delight on thy verdure reposes,

A tranquil and delieate shade.

But ah! what dejeetion that foliage expresser

Whiel pensively droops on her breast!

The dew of the evening has laden her tresses, And stands like a tear on her erest.

I'l! wateh by thy side through the gloom of the Impatient till morning appears:

No eharm ean awaken this heart to delight,

My Jessamine, while thou art in tears. 
But soon will the shadows of night be withdrawn, Which ever in mercy are given; And thou shalt be cheered by the light of the morn, And fanned by the breezes of hcaven.

And still may the tranquil and delicate shade Yield fragrance and solace to me;

For though all the flowers in my garden should fadc My heart will repose upon thee.

\section{ON A FADED VIOLET.}

BY SHELLY.

THE odour from the flower is gone Which, like thy kisses, breathed on me; The colour from the flower is flown, Which glowed of thee, and only thee!

A shrivelled, lifeless, vacant form, It lies on my abandoned breast, And mocks the heart, which yet is warm,

With cold and silent rest.

I wecp, - my tears rcvive it not !

I sigh, -it brcathes no morc on me; Its mute and uncomplaining lot

Is such as mine should be.

\section{DAWN, GENTLE FLOWER.}

\section{BY BARRY CORNWALL.}

DAWN, gentle flower,

From the morning earth !

We will gaze and wonder

At thy wondrous birth ! 
Bloom, gentle flower!

Lover of the night,

Sought by wind and shower,

Fondled by the night!

Fade, gentle flower!

All thy white leaves elose ;

Having shone thy beauty,

Time 'tis for repose.

Die, gentle flower,

In the silent sun!

So-all pangs are over,

All thy tasks are done!

Day hath no more glory, 'Though he soars so high ;

Thine is all man's storylive-and love-and die!

THE LILY AND THE ROSE.

BY COWPER.

THE nymph must lose her female friend,

If more admired than she-

But where will fieree eontention end,

If flowers can disagree?

Within the garden's peaeeful secne

Appeared two lovely foes,

Aspiring to the rank of queen-

The Lily and the Rose.

The Rose soon reddened into rage,

And, swelling with disdain, Appealed to many a poet's page

'To prove her right to reign. 


\section{The Poetry of Flowers.}

'The Lily's height bespoke eommand,

A fair imperial flower;

She seemed designed for Flora's hand,

The seeptre of her power.

This eivil biekering and debate

The goddess ehaneed to hear;

And flew to save, ere yet too late,

The pride of the parterre.

"Yours is," she said, " the noblest hue,

And yours the statelier mien;

And, till a third surpasses you,

Let each be deemed a queen."

Thus soothed and reeoneiled, botl seck

The fairest British fair ;

The seat of empire is her eheek,

They reign united there.

\section{THE VIOLET. \\ BY SCOTT.}

THE Violet in her greenwood bower,

Where birehen boughs with hazels mingle,

May boast herself the fairest flower

In glen, or eopse, or forest dingle.

Though fair her gems of azure hue,

Beneath the dew-drop's weight reelining,

I've seen an eye of lovelier blue,

More sweet through watery lustre shining.

The summer sun that dew shall dry, Ere yet the day be past its morrow;

No longer in my false love's eye

Remained the tear of parting sorrow. 
THE DYING GIRL AND FLOWERS.

BEAR them not from grassy dells, Where wild bees have honey-cells ; Not from where sweet watcr-souncls Thrill the greenwood to its bounds; Not to waste their scented breath On the silent room of Death !

Kindred to the breeze they are, And the glow-worm's emcrald star; And the bird, whose song is free, And the many-whispering tree: Oh ! too deep a love, and fain, They would win to earth again.

Spread them not before the eyes Closing fast on summer skies! Woo thou not the spirit back From its lone and viewless track, With the bright things which have birth Wide o'er all the coloured earth 1

With the Violet's breath would rise Thoughts too sad for her who dies ; From the Lily's pearl-cup shed, Dreams too siveet would haunt her bed; Dreams of youth - of spring-time eves--. Music-beauty-all she leaves !

Hush 1 'tis thou that dreaming art, Calmer is her gentle heart.

Yes l o'er fountain, valc, and grove, Leaf and flower, hath gushed her love; But that passion, deep and true, Knows not of a last adieu. 
Types of lovelier forms than these,

In their fragile mould she sees;

Shadows of yet richer things,

Born beside immortal springs,

Into fuller glory wrought,

Kindled by surpassing thought.

Therefore in the Lily's leaf

She can read no word of grief ;

O'er the Woodbine she can dwell,

Murmuring not-Farewell! farewell!

And her dim, yet speaking eye,

Greets the Violet solemnly.

Therefore, once, and yet again,

Strew them o'er her bed of pain ;

From her chamber take the gloom,

With a light and flush of bloom :

So should one depart, who goes

Where no deatl can touch the Rose.

\section{THE NIGHT-SHADE.}

BY BARRY CORNWALL.

TREAD aside from my starry bloom !

I am the nurse who feed the tomb

(The tomb, my child),

With dainties piled,

Until it grows strong as a tempest wild.

Trample not on a virgin flower!

I am the maid of the midnight hour;

I bear sweet sleep

'To those who weep,

And lie on their eyelids dark and deep. 
Tread not thou on my snaky eyes $\downarrow$

I am the worm that the weary prize,

The Nile's soft asp,

That they strive to grasp,

And one that a queen has loved to clasp!

Pity me! I am she whom man

Hath hated since ever the world began ;

I soothe his brain,

In the night of pain,

But at morning he waketh-and all is in vain.

\section{THE LAY OF THE ROSE.}

BY ELIZABETH BROWNING BARRETT.

"Discordance that can accord; And accordance to discord."

The Romaunt of the Rose.

A ROSE once passed within

A garden, April-grcen,

In her loneness, in her loneness.

And the fairer for that oneness.

A white Rose, delicate,

On a tall bough and straight,

Early comer, April comer,

Never waiting for the Summer;

Whose pretty gestes did win

South winds to let her in,

In her loneness, in her loneness,

All the fairer for that oneness.

"For if I wait," said she,

"Till times for roses be,

For the musk Rose, and the moss Rose

Royal red and maiden blush Rose, 


\section{The Poctry of Flowers.}

" What glory then for me,

In such a company?

Roses plenty, roscs plenty,

And one nightingale for twenty !

"Nay, let me in," said she,

"Before the rest are free,

In my loneness, in my loneness,

All the fairer for that onencss.

"For I would lonely stand,

Uplifting my white hand,

On a mission, on a mission,

To declare the coming vision.

"Sec mine, a holy heart,

To high ends set apart-

All unmatcd, all unmated,

Because so consecrated.

"Upon which lifted sign,

What worship will be mine!

What addressing, what caressing,

What thanks, and praise, and blessing!

"A wind-like joy will rush

Through evcry tree and bush,

Bending softly in affection, And spontaneous benediction.

"Insects, that only may

Live in a sun-bright ray,

To my whiteness, to my whitencss,

Shall be drawn, as to a brightness,

"And every moth and bee

Shall ncar me reverently,

Wheeling round me, wheeling o'cr me, Coronals of motioned glory. 
"I wecn the very skies

Will look down in surprise

When low on earth thcy see me,

With my cloudy aspect dreamy.

" E'en nightingales shall flee

Their woods for love of me,

Singing sadly all the suntide,

Never waiting for the moontide!

"'Three larks shall leave a cloud

To my whiter beauty vowed, Singing gladly all the moontide, Never waiting for the suntide."

So praying did she win South winds to let her in,

In her loneness, in her loneness, And the fairer for that oneness.

But out, alas! for her,

No thing did minister

To her praises, to her praises, More than might unto a daisy's.

No tree nor bush was seen

To boast a perfect grcen,

Scarcely having, scarcely having One leaf broad enow for waving.

The little flies did crawl

Along the southern wall,

Faintly shifting, faintly shifting

Wings scarce strong enow for lifting.

The nightingale did plcase

To loiter beyond seas,

Guess him in the happy islands, Hearing music from the silence. 
The lark too high or low,

Did haply miss her so-

With his crest down in the gorses,

And his song in the star-courses!

Only the bee, forsooth,

Came in the place of both-

Doing honour, doing honour,

To the honey-dews upon her.

The skies looked coldly down,

As on a royal crown ;

Then, drop by drop, at leisure,

Began to rain for pleasure.

Whereat the earth did seem

To waken from a dream-

Winter frozen, winter frozen,

Her anguish eyes unclosing,

Said to the Rose, " $\mathrm{Ha}$, Snow!

And art thou fallen so?

Thou who wert enthronéd statcly

Along my mountains lately.

"Hullo, thou world-wide snow!

And art thou wasted so ?

With a little bough to catch thec,

And a littlc bee to watch thec?"

Poor Rose, to bc misknown?

Would she had ne'er bcen blown,

In hor loneness, in her loneness,

All the sadder for that onencss.

Some words she tried to say,

Some sigh - ah, well away!

But the passion did o'ercome her,

And the fair frail leaves dropped from her. 
Dropped from her, fair and mute,

Close to a poet's foot, Who beheld them, smiling lowly, As at something sad yet holy:

Said, "Verily and thus,

So chanceth e'er with us,

Poets, ringing sweetest snatches,

While deaf men did keep the watches.

"Saunting to come before

Our own age evermore,

In a loneness, in a loneness,

And the nobler for that oneness.

"But if alone we be

Where is our empiry?

And if none can reach our stature,

Who will mate our lofty nature?

"What bell will yield a tone

Save in the air alone?

If no brazen clapper bringing, Who can bear the chimed ringing?

" What angel but would seem

To sensual eyes glent-dim?

And without assimilation,

Vain is interpenetration!

"Alas! what can we do,

The Rose and poet too, Who both antedate our mission

In an unpreparéd season?

"Drop, leaf-be silent, song-

Cold things we came among!

We must warm them, we must warm them, Ere we even hope to charm them. 
"Howbeit"-here his face

Heightened around the place, So to mark the outward turning Of his spirit's inward burning"Something it is to hold In God's world's manifold, First revealed to creatures duty, A new form of His mild beauty.

"Whether that form respect

The sense or intellect, Holy rest in soul or pleasance, The chief beauty's sign of presence.

"Holy in me and thee,

Rose fallen from the tree, Though the world stand dumb around us, Ail unable to expound us.

"Though none us design to bless,

Blessed are we natheless; Blessed age and consecrated! In that, Rose, we were created ! "Oh, shame to poet's lays, Sung for the dole of praiseHoarsely sung upon the highway, With an 'obolum da miki"!

"Shame! shame to poet's soul,

Pining for such a dole, When heaven-called to inherit The high throne of his own spirit !

"Sit still upon your thrones,

O ye poctic ones! And if, sooth, the world decry you, Why, let that world pass by you! 
'Ye to yoursclves suffice,

Without its flatteries;

Self-contentedly approve you

Unto Him who sits above you.

"In prayers that upward mount,

Like to a sunnéd fount,

And, in gushing back upon you, Bring the music they have won you !

"In thanks for all the good

By poets understood-

For the sound of seraphs moving

Through the hidden depths of loving !

"For sights of things away,

Through fissures of the clay-

Promised things, which shall be given And sung ever up in heaven!

"For life, so lonely vain,

For death, which breaks the chainFor this sense of present sweetness, And this yearning to completeness !

\section{EMBLEMS OF FLOWERS.}

\section{BY BURNS.}

ADown winding Nith I did wander,

To mark the sweet flowers as they spring ! Adown winding Nith I did wander,

Of Phillis to muse and to sing.

The Daisy amused my fond fancy,

So artless, so simple, so wild ;

Thou emblem, said I, o' my Phillis,

For she is simplicity's child. 
The Rosebud's the blush o' my charmer, Her sweet balmy lip when 'tis prest :

How fair and how pure is the Lily, But fairer and purer her breast.

Yon knot of gay flowers in the arbour,

They ne'er wi' my Phillis can vie:

Her breath is the breath of the Woodbinc, Its dew-drop o' diamond her eye.

Her voice is the song of the morning,

That wakes through the green-spreading grove,

When Phobus peeps over the mountains,

On music, and pleasure, and love.

But beauty how frail and how fleeting,

The bloom of a fine summer's day!

While worth in the mind o' my Phillis

Will flourish without a decay.

\section{THE ORANGE-BOUGH.}

BY MRS. HEMANS.

$\mathrm{OH} !$ bring me one swect Orange-bough, To fan my cheek, to cool my brow; One bough, with pearly blossoms drest, And bind it, mother, on my breast!

Go, seek the grove along the shore, Whose odours I must breathe no morcThe grove where every scentcd tree Thrills to the deep voice of the sea.

Oh! Love's fond sighs, and fervent prayer, And wild farewell, are lingering there; Each leaf's light whisper hath a tone My faint heart, even in death, would own. 
'Then bear me thence one bough, to shed

Life's parting sweetness round my head,

And bind it, mother, on my breast,

When I am laid in lonely rest.

\section{TO THE NARCISSUS.}

BY BEN JONSON.

ARISE, and spenk thy sorrows, Echo, rise;

Here, by this fountain, where thy love did pine,

Whose memory lives fresh to vulgar fame,

Shrined in this yellow flower, that bears his name,

ЕсHо.

His name revives, and lifts me up from earth ; -

See, see the mourning fount, whose springs weep yet

'Th' untimely fate of that too beauteous boy,

That trophy of self-love, and spoil of nature,

Who (now transformed into this drooping flower)

Hangs the repentant head back from the stream;

As if it wished-would I had never looked

In such a flattering mirror! $\mathrm{O}$, Narcissus!

Thou that wast once (and yet art) my Nareissus.

Had Echo but been private with thy thoughts,

She would have dropt away herself in tears,

Till she had all turned waste, that in her

(As in a true glass) thou might'st have gazed, And seen thy beauties by more kind reflection. But self-love never yet could look on truth, But with bleared beams; slick flattery and she Are twin-born sisters, and do mix their eyes, As if you sever one, the other dies. Why did the gods give thee a heavenly form, And earthly thoughts to make thee proud of it? Why do I ask? "Tis now the known disease 
That Beauty hath, to bear too dcep a sense

Of her own self-conceivéd excellence.

[gift,

Oh 1 hadst thou known the worth of Heaven's rich Thou would'st have turned it to a truer use. And not (with starved and covctous ignorance)

Pined in continual eyeing that bright gem, The glance whereof to others had been more Than to thy famished mind the wide world's store.

\section{THE HAREBELL.}

BY SCOTT.

"For me," she stopped, and, looking round,

Plucked a blue Harebell from the ground,-

"For me, whose memory scarce conveys

An image of more splendid days,

This little flower that loves the lea,

May well my simple emblem be ;

It drinks heaven's dew, blithe as the Rose

That in the king's own garden grows;

And when I place it in my hair, Allan, a bard is bound to swear

He ne'er saw coronet so fair."

\section{THE HALF-BLOWN ROSE.}

\section{BY DANIEL.}

Look, now, now we esteem the half-blown Rose, The image of thy blush and summer's honour; Whilst yet her tender bud doth undisclose

That full of beauty time bestows upon her. No sooner spreads her glories to the air,

But straight her wide-blown pomp comes to decline ; 
She then is scorned that late adorned the fair;

So fade the roses of those cheeks of thine. No April can revive thy withered flowers,

Whose springing grace adorns thy glory now ; Swift, speedy time, feithered with flying hours,

Dissolves the beauty of the faircst brow: Then do not thou such treasure waste in vain, But love now whilst thou may'st be loved again.

\section{TO THE DAISY.}

\section{BY WORDSWORTH.}

IN youth from rock to rock I went,

From hill to hill in discontent, Of pleasure high and turbulent, Most pleased when inost uneasy ;

But now my own delights I makc, -

My thirst at every rill can slake, And naturc's love of thee partake, Her mueh-loved Daisy!

Thee Winter in the garland wears That thinly decks his few grcy hairs; Spring parts the clouds with softest airs, That she may sun thee;

Wholc summer-fields are thine by right; And Autumn, mclancholy wight! Doth in thy crimson head delight, When rains are on thee.

Be Violcts in thcir secret mews

The flowers the wanton zephyrs choose:

Proud be the Rose, with rains and dews Her head impearling : 
Thou liv'st with less ambitious aim,

Yet hast not gone without thy fame ;

Thou art indeed, by many a claim, The poet's darling.

If to a rock from rains he fly,

Or, somc bright day of April sky, Imprisoned by hot sunshine, lie

Near the green holly,

And wearily at length should farc ;

He necds but look about, and there

Thou art ! - a friend at hand, to scare His melancholy.

A hundred times, by rock or bower, Ere thus I have lain couched an hour, Have I derived from thy sweet power Some apprehension ; Some steady love, some brief dclight, Some memory that had taken flight, Some chime or fancy wrong or riglit,

Or strong invention.

If stately passions in me burn, And one chance look to thec should turn, I drink out of an humbler urn

A lowlier pleasure;

The homely sympathy that heeds

The common life our nature breeds ;

A wisdom fitted to the needs

Of hearts at leisure.

Fresh smitten by thy morning ray,

When thou art up, alert and gay,

Then, cheerful flower, my spirits play With kindred gladness : And when, at dusk, by dews opprest, 
Thou sink'st, the image of thy rest Hath often eased my pensive breast Of careful sadness.

And all day long I number yet, All seasons through, another debt, Which I, wherever thou art met, To thee am owing ;

An instinct call it, a blind sense-

A happy, genial influence,

Coming one knows not how, nor whence,

Nor whither going.

Child of the year! that round dost run 'Thy pleasant course--when day's begun, As ready to salute the sun

As lark or leveret,

Thy long-lost praise* thou shalt regain ;

Nor be less dear to future men

Than in old time; -thou not in vain Art Nature's favourite,

\section{LOVE'S WREATH.}

BY MOORE.

WHEN Love was a child, and wếnt idling round Among flowers the whole summer's day,

One morn in the valley a bower he found, So sweet. it allured him to stay.

O'erhead from the trees hung a garland fair,

A fountain ran darkly beneath;
'Twas Pleasure that hung the bright flowers uf Love knew it and jumped at the wreath.

* See in Chaucer and the elder poets, the honours formerly p.id to this flower. 
But Love did not know-and at his weak years, What urchin was likely to know?-

That sorrow had made of her own salt tears

That fountain which murmured below.

He caught at the wreath, but with too much haste, As boys when impatient will do ; It fell in those waters of briny taste, And the flowers were all wet through.

Yet this is the wreath he wears night and day ; And though it all sunny appcars With Pleasure's own lustre, cach leaf, they say, Still tastes of the fountain of tears.

\section{TO A CROCUS.*}

B Y BERNARD BARTON.

WELCOME, mild harbinger of Spring !

To this small nook of earth,

Feeling and fancy fondly cling

Round thoughts which owe their birth

To thce, and to the humble spot

Where clance has fixed thy lowly lot.

To thee-for thy rich golden bloom,

Like heaven's fair bow on high,

Portends, amid surrounding gloom,

That brighter hours draw nigh,

When blossoms of more varied dyes

Shall ope their tints to warmer skies.

" Growing up and blossoming beneath a Walinower. 
Yet not the Lily, nor the Rose, Though fairer far they be, Can more delightful thoughts diselose Than I derive from thee :

The eye their beauty may prefer ; The heart is thy interpreter!

Methinks in thy fair flower is seen, By those whose fancies roam, An emblem of that leaf of green

The faithful dove brought home, When o'er the world of waters dark Were driven the inmates of the ark.

That leaf betokened freedom nigh To mournful captives there; Thy flower foretells a sunnier sky, And chides the dark despair By Winter's chilling influence flung O'er spirits sunk and nerves unstrung.

And sweetly has kind Nature's hand Assigned thy dwelling-place Beneath a flower whose blooms expand, With fond congenial grace, On many a desolated pile, Bright'ning decay with Beauty's smile.

Thine is the flower of Hope, whose hue Is bright with coming joy;

The Wallfower's that of Faith, too true For ruin to destroy ; And where, oh! where should Hope upspring, But under Faith's proteeting wing? 


\section{ARRANGEMENT OF A BOUQUET.}

\section{BY NICHOLAS DRAYTON.}

Here damask Roses, white and red, Out of my lap first take I, Which still shall run along the thread, My chiefcst flower this make I.

Amongst these Roses in a row, Next place I Pinks in plenty,

These double Pansies then for show: And will not this be dainty?

The pretty Pansy then I'll tie, Like stones some chain inchasing : And next to them, their near ally,

The purple Violet placing.

The curious choice clove July flower, Whose lind hight the Carnation, For sweetness of most sovereign power, Shall help my wreath to fashion ;

Whose sundry colours of one kind, First from one root derived, Them in their several suits I'Il bind: My garland so contrived.

A course of Cowslips then I'll stick, And here and there (though sparely) The pleasant Primrose down I'll prick, Like pearls that will show rarely ;

Then with thcse Marigolds I'll make My garland somewhat swclling, These Honeysuckles then I'll take, Whose sweets shall help their smelliug. 
The Lily and the Fleur-de-lis, For colour much contending ; For that I them do only prize,

They are but poor in scenting.

The Daffodil most dainty is, To match with these in meetness ;

The Columbine compared to this, All much alike for sweetness.

These in their natures only are

Fit to emboss the border, Therefore I'll take especial care To place thcm in their order:

Sweet-willians, Campions, Sops-in-wine, One by another neatly:

Thus have I made this wreath of mine, And finishéd it featly.

\section{ON PLANTING A TULIP-ROOT.}

BY MONTGOMEIRY.

HERE lies a bulb, the child of earth, Buried alive beneath the clod, Ere long to spring, by second birth, A new and nobler work of God.

'Tis said that microscopic power Might through his swaddling folds descry The infant image of the flower, Too exquisite to meet the eye.

This vernal suns and rains will swell, Till from its dark abode it peep, Like Venus rising from her slell, Amidst the spring-tide of the deep. 
Two shapely leaves will first unfold ;

Then on a smooth, elastic stem, The verdant bud shall turn to gold, And open in a diadem.

Not one of Flora's brilliant race

A form more perfect can display ; Art could not feign more simple grace,

Nor Nature take a line away.

Yet, rich as morn, of many a hue,

When flushing clouds through darkness strike,

The Tulip's petals shine in dew

All beautiful, but none alike.

\section{TO BLOSSOMS.}

BY HERRICK.

FAIR pledges of a fruitful tree,

Why do ye fall so fast?

Your date is not so past,

But you may stay here yet awhile,

To blush and gently smile,

And go at last.

What! were ye born to be

An hour or half's delight,

And so to bid good-night?

"Twas pity Nature brought ye forth

Merely to show your worth,

And lose you quite. 
But ye are lovely leaves, where we

May read how soon things have

Their end, though ne'er so brave; And after they have shown their pride,

Like you, awhile, they glide Into the grave.

\section{THE EARLY PRIMROSE.}

AskE me why I send you here This firstling of the infant year ; Aske me why I send to you 'This Primrose all bepearled with dew ; I straight will whisper in your ears, The sweets of love are washt with teares.

Aske me why this flower doth show So yellow, green, and siekly too; Aske me why the stalk is weak . And bending, yet it doth not break ; I must tell you, these diseover What doubts and fears are in a lover.

\section{THE HOLLY.}

BY SOUTHEY.

O READER ! hast thou ever stood to see The holly tree?

The eye that contemplates it well pereeives Its glossy leaves,

Ordered by an Intelligence so wise, As might eonfound the Atheist's soplistries. 
Below a eircling fencc, its leaves are scen,

Wrinkled and keen ;

No grazing cattle through their priekly round

Can reach to wound,

But as they grow where nothing is to fear,

Smooth and unarmed the pointlcss leaves appear.

\section{ANACREON TO THE ROSE.}

WHILE we invole the wreathed Spring, Resplendent Rose! to thee we'll singRcsplendent Rose! the flower of flowers, Whose breath perfumes Olympus' bowers, Whose virgin blush, of chastened dye, Enchants so much our mortal eye.

Oft has the poet's magic tongue The Rose's fair luxuriance sung ; And long the Muses, heavenly maids, Have reared it in their tuneful shades. When, at the carly glance of morn, It sleeps upon the glittcring thorn, "Tis sweet to dare the tangled fencc, To cull the timid floweret thence, And wipe, with tender hand, away The tear that on its blushes lay! 'Tis sweet to hold the infant stems, Yct dropping with Aurora's gcms, And fresh inliale the spicy sighs That from the weeping buds arise. When revel reigns, when mirth is high, And Bacchus beams in every eye, Our rosy fillets scent exhale, And fill with balm the fainting gale. 
Oh! there is nought in nature bright, Where Roses do not shed their light; Where morning paints the orient skies, Ier fingers burn with roseate dyes; And when, at length, with pale deeline, Its florid beauties fade and pine, Sweet as in youth its balmy breath Diffuses odour e'en in death! Oh! whence could such a plant have sprung? Attend-for thus the tale is sung :-When humid from the silvery stream, Effusing beauty's warmest beam, Venus appeared in flushing hues, Mellowed by ocean's briny dews; When, in the starry eourts above, 'The pregnant brain of mighty Jove Disclosed the nymph of azure glanceThe nymph who shakes the martial laneeThen, then, in strange eventful hour, The earth produced an infant flower, Which sprung with blushing tinetures dressed, And wantoned o'er its parent breast. The gods beheld this brilliant birth, And hailed the Rose, the boon of earth, With neetar drops, a ruby tide, The sweetly crient buds they dyed, And bade then bloom, the flowers divine Of him who sheds the teeming vine ; And bade them on the spangled thorn Expand their blossoms to the morn. 


\section{DECISION OF THE FLOWER.}

\section{BY L. E. L.}

AND with scarlet Poppies, around like a bowcr, The maiden found her mystic flower. "Now, gentle flower, I pray thee, tell If my lover loves me, and loves me wcll: So may the fall of the morning dew Kcep the sun from fading thy tender blue. Now I number the leaves for my lotHe loves not-he loves me- he loves me notHe loves me-yes, thou last leaf, yesI'll pluck thce not for the last sweet guess! He loves me!"- "Yes," a dear voice sighed, And her lover stands by Margarct's side.

\section{THE SHEPHERD TO THE FLOWERS.}

\section{BY SIR WALTER RALEIGH.}

SWEET Violets, love's paradise, that spread Your gracious odours, which you, couchéd, bear

Within your paly faccs,

Upon the gentle wing of some calm-breathing wind,

That plays amidst the plain!

If, by the favour of propitious stars, you gain Such grace as in my lady's bosom place to find, Be proud to touch those places:

And when her warmth your moisture forth doth wcar, Whereby her dainty parts are sweetly fed, You, honours of the flowcry meads, I pray, You pretty daughters of the earth and sun, With inild and seemly breathing straight display My bitter sighs, that have my heart indone! 


\section{HEART'S-EASE.}

BY SHAKESPEARE.

I SAW,

Flying between the cold moon and the eartl, Cupid all armed; a certain aim he took At a fair vessel thronéd in the west, And loosed his love-shaft smartly from his bow, As it should pierce a hundred thousand hearts. But I might see young Cupid's fiery shaft Quenched in the chaste beams of the watery moon, And the imperial vot'ress passed on, In maiden meditation, fancy-free. Yet marked I where the bolt of Cupid fell :

It fell upon a little western flowcr, Bcfore milk-whitc, now purple with love's wound, And maidens call it Love in Idleness. The juice of it, on sleeping eyelids laid, Will make a man or woman madly dote Upon the next live creature that it sees.

\section{THE SCARLET GERANIUM.}

I WILL not sing the mossy Rose, The Jasmine swcet, or Lily fair, The tints the rich Carnation shows, The Stock's swcet scent that fills the air.

Full many a bard has sung their praise In metres smooth, and polished line;

A simple flower and humbler lays May best befit a pen like mine.

There is a small but lovely flower, With crimson star and calyx brown, 


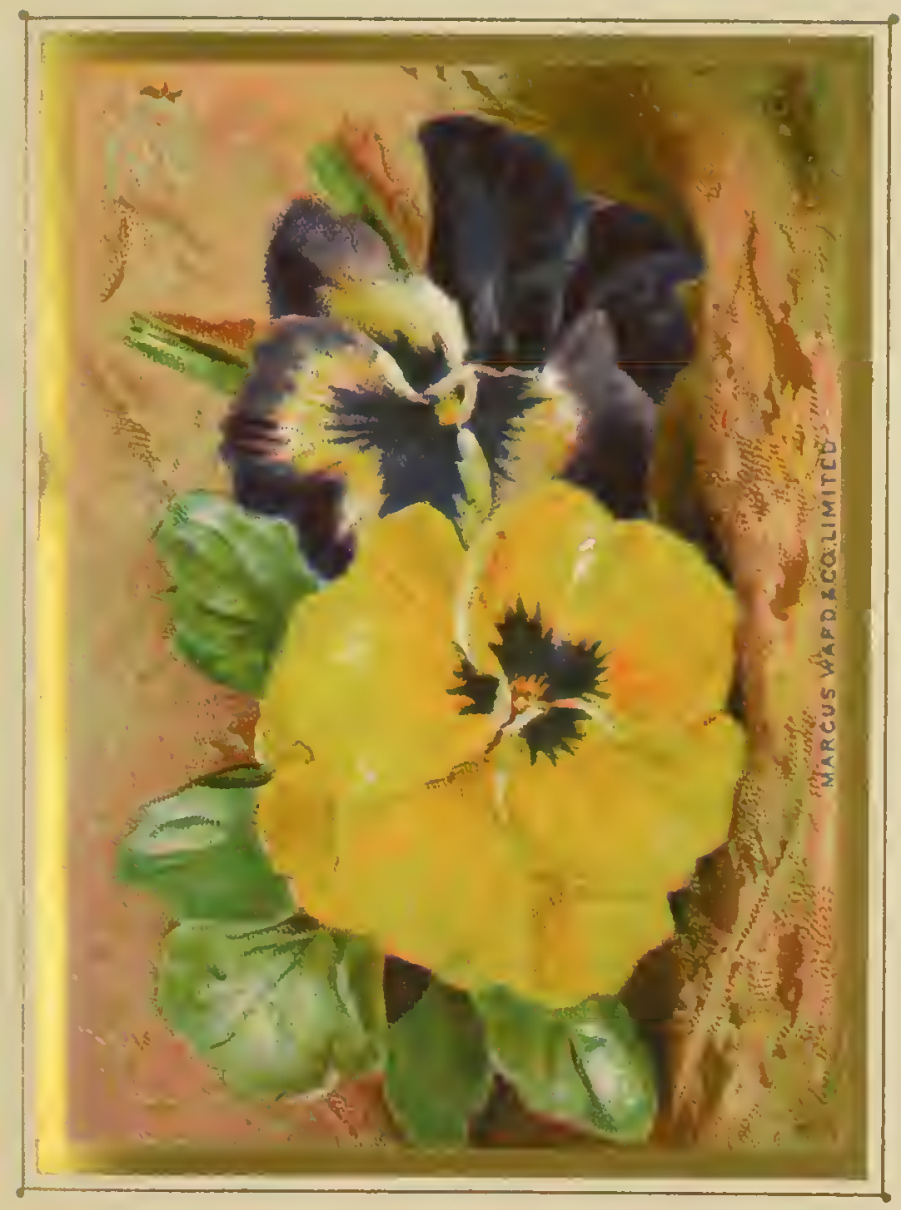





\section{The Poetry of Flowers.}

On pathway side, beneath the bower, By Nature's hand profusely strown.

Inquire you when this flow'ret springs?When Nature wakes to mirth and love, When all her fragranee Summer flings,

When latest Autumn ehills the grove.

Like the sweet bird whose name it bears, 'Midst falling leaves and fading flowers, The passing traveller it eheers,

In shortened days and darksome hours.

And should you ask me where it blows,

I answer, on the mountains bare,

High on the tufted roek it grows,

In lonely glens or meadows fair.

It blooms amidst those flowery dales, Where winding Aire pursues its eourse;

It smiles upon the eraggy fells That rise around its lofty souree.

There are its rosy petals shown, 'Midst eurious forms and mosses rare, Imbedded in the dark grey stone, When not another flower is there.

Oh! emblem of that steadfast mind Whieh, through the varying seenes of life, By genuine piety refined,

Holds on its way 'midst noise and strife.

Though dark the impending tempest lower, 'The path of beauty it espies,

Calm 'midst the whirlwind and the shower, Thankful when brighter hours arise. 
Oh! could our darkened minds discern In thy swect form this lesson plain, Could we it practically learn, Herb Robert would not bloom in vain.

\section{$\longrightarrow$ \\ THE HELIOTROPE.}

THERE is a flower, whose modest eye

Is turned with looks of light and love, Who breathes her softest, sweetest sigh,

Whene'er the sun is bright above.

Let clouds obscure, or darkness veil,

Her fond idolatry is fled;

IIcr sighs no more their sweets exhale,

The loving cye is cold and dead.

Can'st thou not trace a moral here,

False flatterer of the prosperous hour?

Lct but an advcrse cloud appear,

And thou art faithless as the flower.

\section{AMOUR OF THE ROSE.}

Young Love, rambling through the wood,

Found me in my solitude,

Bright with dew and freshly blown,

And trembling to the zephy:'s sighs;

But as he stopped to gaze upon

The living gem with rapturcd eyes,

It chanced a bee was busy thcre,

Scarching for its fragrant fare ; 
And Cupid, stooping too, to sip, The angry insect stung his lip ;

And, gushing from the ambrosial eell,

One bright drop on my bosom fell.

Weeping, to his mother he

Told the tale of treaehery,

And she, her vengeful boy to please,

Strung his bow with eaptive bees,

But plaeed upon my slender stem

The poisoned sting she plueked from them;

And none sinee that eventful morn

Have found the flower without a thorn.

THE FORGET-ME-NOT.

Not on the mountain's shelving side

Nor in the eultivated ground,

Nor in the garden's painted pride,

The flower I seek is found.

Where Time on sorrow's page of gloum

Has fixed its envious lot,

Or swept the reeord from the tomb,

It says, Forget me not.

And this is still the loveliest flower,

The fairest of the fair,

of all that deek my lady's bower,

Or bind her fioating hair. 


\section{THE EVENING PRIMROSL.}

BY BEIRNARD BAR'TON.

FAIR flower, that shunn'st the glare of diay, Yet lov'st to open, meekly bold,

'To evening hues of sober grey, Thy cup of paly gold;

Be thine the offcring, owing long,

To thee, and to this pensive hour,

Of the brief tributary song,

Though transient as thy nower.

I love to watch at silent eve

Thy scattered blossoms' lonely light ;

And have ny inmost heart receive

The influence of that sight.

I love, at such an hour, to mark

Thcir beauty greet the light brcezc chill, And shine, 'mid shadows gathering dark,

The garden's glory still.

For such, 'tis sweet to think the while,

Whon carcs and griefs the breast invade,

In fricndship's animating smile,

In sorrow's dark'ning shade.

Thus it bursts forth like thy pale cup,

Glist'ning amid its dcwy tears,

And bears the sinking spirit up

Amid its chilling fears;

But still more animating far,

If meck religion's cye may trace,

Even in thy glimm'ring earth-born star, The holier hope of grace! 


\section{The Poetry of Flowers.}

The hope that, as thy beauteous bloom

Expands to glad the close of day, So through the shadows of the tomb

May brcak forth mercy's ray.

\section{TO AN EARLY PRIMROSE.}

BY H. K. WHITE.

MILD offspring of a dark and sullen sire!

Whose modest form, so delicately fine,

Was nursed in whirling storms,

And cradled in the wind.

Thee, when young Spring first questioned Winter's sway,

And dared the sturdy blusterer to the fight-

Thee on this bank he threw,

To mark his victory.

In this low vale, the promisc of the ycar, Screne thou openest to the nipping gale,

Unnoticed and alone,

Thy tender elegance.

So Virtue blooms, brought forth amid the storms

Of chill adversity, in some lone walk

Of life she rears her head,

Obscure and unobserved;

While every bleaching brceze that on her blows Chastens her spotless purity of breast,

And hardens her to bear

Serene the ills of life. 


\section{THE ROSE-BUD. \\ BY KEBLE.}

When Nature trics her finest touch,

Waving her vernal wreath,

Mark ye how close she veils her round,

Not to be traced by sight or sound,

Nor soiled by ruder breath?

Whoever saw the earliest Rose

First open her sweet breast?

Or, when the summer sun goes down,

The first soft star in evening's crown

Light up her gleaming erest ?

Fondly we seel the dawning bloom

On features wan and fair,-

The gazing eye no change can trace,

But look away a little space,

Then turn, and 10 ! 'tis there.

But there's a sweeter flower than e'er

Blushed on the rosy spray-

A brighter star, a richer bloom,

Than e'er did western heaven illume At close of summer day.

'Tis love, the last best gift of heaven ; Love gentle, holy, pure:

But tenderer than a dove's soft eye,

The searching sun, the open sky,

She never could endure.

Even human love will shrink from sight

Here in the coarse, rucle earth:

How then should rash intruding glance Break in upon her sacred trance,

Who boasts a heavenly birth? 
So still and secret is her growth, Ever the truest heart,

Where deepest strikes her kindly root, For hope or joy, for flower or fruit,

Least known its happy part.

God only, and good angels, look Behind the blissful sereenAs when, triumphant o'er His woes, The Son of God by moonlight rose, By all but heaven unseen :

As when the Holy Maid beheld Her risen Son and Lord:

Thought has not colours half so fair, That she to paint that hour may dare In silenee best adored.

The gracious dove, that brought from neaven The earnest of our bliss,

Of many a chosen witness telling, Of many a happy vision dwelling, Sings not a note of this.

So, truest image of the Christ, Old Israel's long-lost Son, What time, with sweet forgiving cheer, He ealled His eonseious brethren near, Would weep with them alone.

He eould not trust his melting soul

But in His Maker's sight--

Then why should gentle hearts and true Bare to the rude world's withering view 'Their treasures of delight? 
No ; lct the dainty Rose awhile

Her bashful fragrance hide-

Rend not her sillken veil too soon,

But leave her, in her own soft noon,

To flourish and abide.

\section{THE GARLAND.}

BY PIRIOR.

THE pride of every grove I chose, The Violet sweet, the Lily fair, The dappled Pink and blushing Rose; To deck my charming Chloe's hair.

At niorn the nymph vouchsafed to place Upon her brow the various wreath ; The flowers less blooming than her face, The scent less fragrant than her breath,

The flowers she wore along the day: And every nymph and shepherd said, That in her hair they looked more gay Than glowing in their native bcd.

Undressed at evening, when she found Their odours lost, their colours past, She changed her look, and on the ground Her garland and her eyes she cast.

That eye dropped sense distinct and clear, As any Muse's tongue could speals, When from its lid a pearly tear

Ran trickling down her beauteous chcek. 
Dissembling what I knew too wel!,

"My love, my life," said I, "explain

This change of humour: pr'ythee tell :

'That falling tear-what does it mean?"

She sighed: she smiled: and to the flowers

Pointing, the lovely moralist said-

"See, friend, in some few fleeting hours,

See yonder, what a change is made.

"Ah me! the blooming pride of May,

And that of beauty, are but one:

At morn both flourished bright and gay ;

Both fade at evening, pale and gone.

"At dawn poor Stella danced and sung,

The amorous youth around her bowed,

At night her fatal knell was rung ;

I saw, and kissed her in her shroud.

"Such as she is, who died to-day,

Such I, alas! may be to-morrow ;

Go, Damon, bid the Muse display

'The justice of thy Chloe's sorrov."

\section{THE FIELD-FLOWER.}

BY MONTGOMERY.

THERE is a flower, a little flower,

With silver crest and golden eye,

That welcomes every changing hour,

And weathers every sky.

The prouder beauties of the field

In gay but quick succession shine,

Race after race their honours yield,

They flourish and decline. 
But this small flower, to nature dear,

Whilc moon and stars their courscs run,

Wreathcs the whole circle of the ycar, Companion of the sun.

It sniles upon the lap of May, To sultry August spreads its cliarms,

Lights pale October on his way, And twines December's arms.

The purple heath, and golden broom, On moory mountains catch the gale ;

$\mathrm{O}^{\prime} \mathrm{cr}$ lawns the Lily sheds perfume, The Violet in the vale;

But this bold flow'ret climbs the hill,

Hides in the forest, haunts the glen,

Stays on the margin of the rill,

Pceps round the fox's den.

Within the garden's cultured round

It shares the sweet Carnation's bcd;

And blooms in consecrated ground

In honour of the dead.

The lambkin crops its crimson gem,

The wild-bee murmurs on its breast,

The blue-fly bends its pensile stem,

Light o'er the skylark's nest.

'Tis Flora's page :-in every place, In every season fresh and fair,

It opens with perennial grace, And blossoms everywhere.

On waste and woodland, rock and plain, Its humble buds unheeded rise ;

The Rose has but a summer rcign, The Daisy never dies. 


\section{TO THE SNOWDROP.}

BY KEBLE.

Trrou first-born of the year's delight, Pride of the dewy glade, In vernal green and virgin white, Thy vestal robes, arrayed :

'Tis not beeause thy drooping form Sinks grateful on its nest, When chilly shades from gathering storm Affright thy tender breast ;

Nor from yon river islet wild Beneath the willow spray, Where, like the ringlets of a ehild, Thou wear'st thy eircle gay;

'Tis not for these I love thee dear, Thy sliy averted smiles

To faney bode a joyous year, One of life's fairy isles.

They twinkle to the wintry moon, And eheer the ungenial day, And tell us all will glisten soon As green and bright as they.

Is there a heart that loves the Spring, Their witness can refuse ; Yet mortals doubt, when angels bring From heaven their Easter news :

When holy maids and matrons speak Of Christ's forsaken bed, And voiees, that forloid to seels The living 'mid the dead; 
And when they say, "Turn, wandering lieart, Thy Lord is risen indeed;

Let pleasure go, put care apart, And to His presence speed ;"

We smile in scorn : and yet we know They early sought the tomb, Their hearts that now so freshly glow, Lost in desponding gloom.

They who have sought, nor hope to find, Wear not so bright a glance:

They who have won their earthly mind, Less reverently advance.

But where, in gentle spirits, fear And joy so duly meet,

These sure have seen the angels near, And kissed the Saviour's feet.

No; let the pastor's thankful eye Their faltering tale disdain, As on their lowly couch they lie, Prisoners of want and pain.

O guide us, when our faithless hearts From "Thee would start aloof, Where Patience her sweet skill imparts Beneath some cottage roof:

Revive our dying fires to burn High as her anthems soar, And of our scholars let us learn Our own forgotten lore. 


\section{HEAR T'S - E A S E.}

BY MRS. SHERIDAN.

IN gardens oft a beauteous flower there grows,

By vulgar eyes unnotieed and unseen ;

In sweet serenity it humbly blows,

And rears its purple head to deek the green.

This flower, as nature's poet sweetly sings,

Was onee milk-white, and Heart's-ease was its name,

Till wanton Cupid poised its roseate wings,

A vestal's saered bosom to inflame.

With treaeherous aim the god his arrow drew,

Which she with iey eoldness did repel,

Rebounding thenee with feathery speed it flew,

Till on this lonely flower, at last, it fell.

Heart's-ease no more the wandering shepherd found ;

No more the nymplis its snowy form possess ;

Its white now ehanged to purple by love's wound,

Heart's-ease no more, -'tis Love in Idleness.

\section{THE ROSE.}

TRANSLATED FROM CAMOENS.

JUST like love is yonder Rose :-

Heavenly fragranee round it throws,

Yet tears its dewy leaves diselose,

And in the midst of briers it blows;

Just like love. 
Culled to bloom upon the breast,

Sinee rough thorns the stem invest, They must be gathered with the rest, And with it to the heart be prest ; Just like love.

And when rude hands the twin buds sever, They die, and they shall blossom never ; Yet the thorns be sharp as ever; Just like love.

\section{GO TO THE FOREST SHADE."} BY MRS. HEMANS.

Go to the forest shade-

Seek thou the well-known glade, Where, heavy with sweet dew, the Violets lie, Gleaming through moss-tufts deep, Like dark eyes filled with sleep, And bathed in hues of summer's midnight sky.

Bring me their buds, to shed Around my dying bed

A breath of May, and of the wood's repose;

For I in sooth depart

With a reluetant heart,

That fain would linger where the bright sun glows.

Fain would I stay with thee-

Alas! this may not be ;

Yet bring me still the gifts of happier hours !

Go where the fountain's breast

Catehes, in glassy rest,

The dim green light that pours through laurel bowers. 


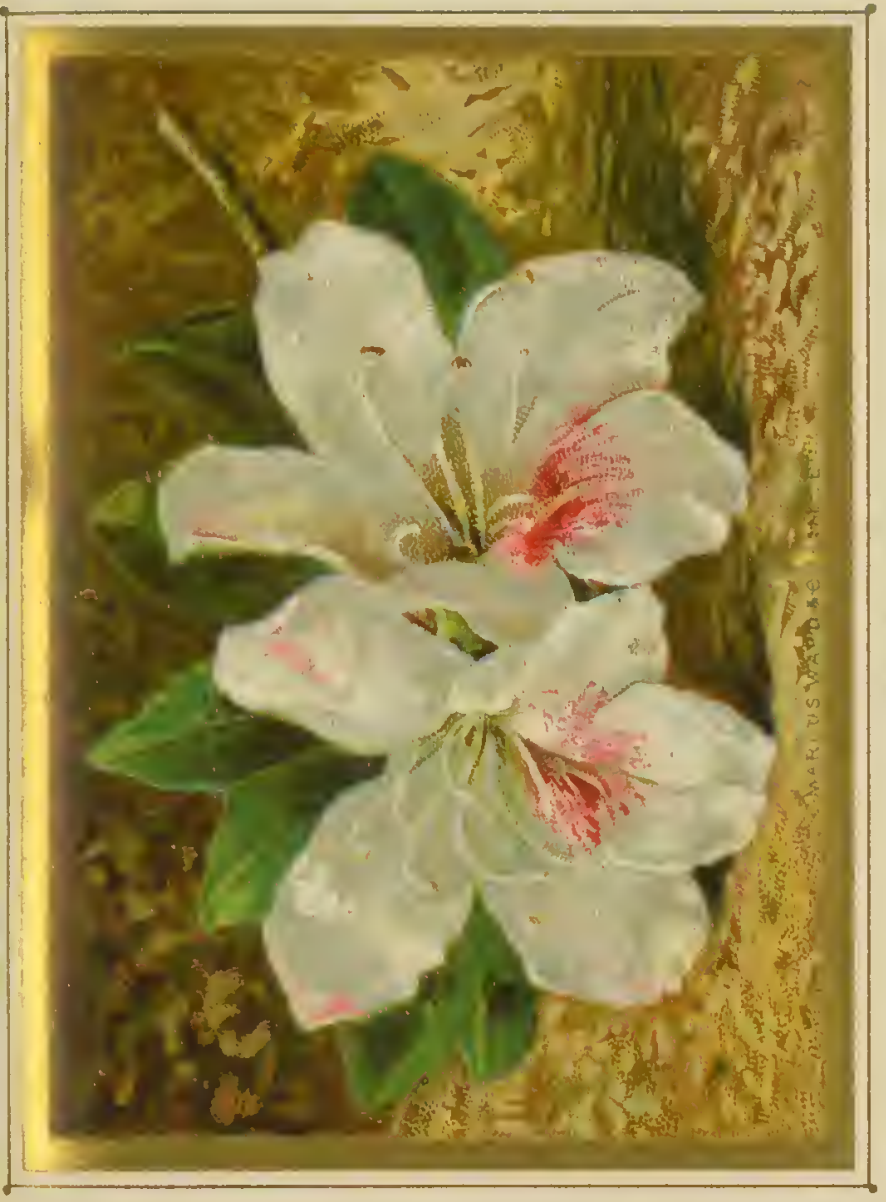



I know how softly bright,

Steeped in that tender light,

The Water-lilies tremble there e'en now ;

Go to the pure stream's edice,

And from its whispering sedge

Bring me those flowers to cool my fevered brow I

Then, as in hope's young days,

Track thou the antique maze

Of the rich garden to its grassy mound ;

There is a lone white Rose,

Shedding, in sudden snows,

Its faint leaves o'er the emerald turf around.

Well know'st thou that fair tree--

A murmur of the bee

Dwells ever in the honied lime above;

Bring me one pearly flower

Of all its clustering shower-

For on that spot we first revealed our love.

Gather one woodbine bough,

Then, from the lattice low

Of the bowered cottage which I bade thee mark,

When by the hamlet last,

Through dim wood-lanes we passed, [spark.

While dews were glancing to the glow-worm's

Haste! to my pillow bear

Those fragrant things and fair,

Thy hand no more may bind them up at eve--

Yet shall their odour soft

One bright dream round me waft

Of life, youth, summer-all that I must leave!

And, ol! ! if thou would'st asls

Wherefore thy steps I task,

The grove, the stream, the hamlet vale to trace, 
"Tis that some thought of me,

When I an gone, may be

The spirit bound to each familiar place.

I bid mine image dwell

(Oh! brcak not thou the spell)

In the deep wood and by the fountain side;

Thou must not, my beloved!

Rove whcre we two have roved,

Forgetting her that in her spring-time died!

\section{TO A JASMINE-TREE}

GROWING IN THE COURT OF HAIVORTH CASTI.E.

BY LORD MORPETH.

MY slight and slender Jasmine-tree,

That bloomest on my Border tower,

Thou art more dearly loved by me,

Than all the wealth of fairy bower.

I ask not, while I near thee dwell,

Arabia's spiec or Syria's rose ;

Thy bright festoons more freshly smell,

Thy virgin white more freshly glows.

My mild and winsome Jasmine-tree,

That elimbest up the dark-grey wall,

Thy tiny flow'rets seem in glee,

Like silver spray-drops down to fall :

Say, did they from their leaves thus peep,

When mailed moss-troopers rode the hill,

When helméd wardens paeed the keep,

And bugles blew for Belted Will ?

My free and feathery Jasmine-tree,

Within the fragranee of thy breath,

Yon dungeon grated to its key,

And the chained captive pined for deatl. 
On Border fray, on feudal erime,

I dream not while I gaze on thee:

The ehieftains of that stern old time

Could ne'er have loved a Jasmine-tree.

\section{TIIE DAISY IN INDIA.}

BY JAMES MONTGOMERY.

THRICE weleome, little English flower!

Thy mother eountry's white and red,

In Rose or Lily, till this hour

Never to me sueh beauty spread:

Transplanted from thy island bed,

A treasure in a grain of earth,

Strange as a spirit from the dead

Thy embryo sprang to birth.

Thrice weleome, little English flower !

Whose tribes beneath our native skies

Shut elose their leaves while vapours lower ;

But when the sun's gay beams arise,

With unabashed but modest eyes,

Follow his motion to the west,

Nor eease to gaze till daylight dies,

Then fold themselves to rest.

Thriee weleome, little English flower!

To this resplendent hemisphere,

Where Flora's giant offspring tower

In gorgeous liveries all the year ;

Thou, only thou, art little here,

Like worth unfriended and unknown,

Yet to my British heart more dear

Than all the torrid zone. 
Thrice welcome, little English flower !

Of early scenes beloved by me,

While happy in my father's bowcr,

Thou shalt the blithe memorial be ;

The fairy sports of infancy,

Youth's golden age, and manhood's prime,

Home, country, kindred, friends-with thee, Are mine in this far clime.

Thrice welcome, little English flower ! I'll rear thee with a trembling hand;

O for the April sun and shower, The sweet May-dews of that fair land, Where Daisies, thick as star-light, stand In every walk! -that here might shoot Thy scions, and thy buds expand, A hundred from one root!

Thrice welcomc, little English flower! To me the pledge of hope unseen : When sorrow would my soul o'erpower For joys that were, or might have been, I'll call to mind, how-fresh and greenI saw thee waking from the dust; Then turn to heaven, with brow serene, And place in God my trust.

\section{THE PRIMROSE OF THE ROCK.}

BY WORDSWORTH.

A ROCK there is whose lonely front The passing travellcr slights;

Yet there the glow-worms hang their lamps, Like stars, at various heights; 
And one eoy Primros? to that roek

The vernal breeze invites.

What hideous warfare hath been waged,

What kingdoms overthrown,

Sinee first I spied that Primrose tuft,

And marked it for my own!

A lasting link in Nature's ehain

From highest heaven let down.

The flowers, still faithful to the stems,

Their fellowship renew ;

The stems are faithful to the root, That worketh out of view ;

And to the roek the root adheres, In every fibre true.

Close elings to earth the living roek, Though threntening still to fall;

The earth is eonstant to her spleere, And God upholds them all :

So blooms this lonely plant, nor dreads Her annual funeral.

Here elosed the meditative strain ;

But air breathed soft that day,

The horry mountain heights were eheered,

'The sunny vale looked gay;

And to the Primrose of the roek

I gave this after lay.

I sang-Let myriads of bright flowers,

Like thee, in field and grove,

Revive unenvied;--mightier far,

Than tremblings that reprove

Our vernal tendencies to hope,

Is God's redeeming love; 
That love whiel ehanged-for wan disease, For sorrow that had bent,

O'er hopeless dust, for withered ageTheir moral element, And turned the thistles of a eurse To types benefieent.

\section{TH E ROSE.}

BY SPENSER.

AH! see the virgin Rose, how sweetly she Doth first peep forth with bashful modesty, That fairer seems the less ye see her way! Lo! see soon after, how more bold and free Her baréd bosom she doth broad display; Lo! see soon after, how she fades away and falls.

\section{THE VIOLET. \\ BY L. E. L.}

IVIIY better than the lady Rose Love I this little flower?

Because its fragrant leaves are those

I loved in ehildhood's hour.

Though many a flower may win my praise, The Violet has my love;

I did not pass my ehildisl days In garden or in grove.

My garden was the window-seat,

Upon whose edge was set

A little vase - the fair, the sweet-

It was the Violet. 
it was my pleasure and iny pride; -

How I did watch its growth;

For health and bloom what plans I tried,

And often injured both!

I placed it in the summer shower,

I placed it in the sun;

And ever at the evening hour,

My work seemed half undone.

The broad leaves spread, the small buds grew,

How slow they seemed to be!

At last there came a tinge of blue,

"Twas worth the world to me!

At length the perfume filled the room,

Shed from their purple wreath ;

No flower has now so rich a bloom-

Has now so sweet a breath.

I gathered two or three-they secmed

Such rich gifts to bestow!

So precious in my sight, I dcemed

That all must think them so.

Oh! who is there but would be fain

To be a child once more,

If future years could bring again

All that they brought before?

My heart's world has been long o'erthrown;

It is no morc of fowers:

Their bloom is passed, their breath is flown;

Yct I rccall those hours.

Let Nature spread her loveliest,

By spring or summer nurst :

Yet still I love the Violet best,

Bccause I loved it first. 


\section{FIELD FLOWERS.}

BY CAMPRELL.

YE field flowers! the gardens eclipse you, 'tis true, Yet, wildlings of naturc, I dote upon you, For ye waft me to summers of old, When the earth teemed around me with fairy delight, And when Daisies and Buttercups gladdened my sight,

Like treasures of silver and gold.

I love thce for lulling me back into drcams

Of the blue Highland mountains and echoing streams,

And of birchen glades breathing thcir balm, While the deer was scen glancing in sunshine remote, And the deep mellow crush of the wood-pigeon's note

Made music that sweetened the calm.

Not a pastoral song has a pleasanter tune Than ye speak to my heart, little wildlings of June:

Of old ruinous castles ye tell,

Where I thought it delightful your beauties to find, When the magic of nature first breathed on my mind, And your blossoms were part of the spcll.

Even now what affections the Violet awakes! What loved little islands, twice seen in their lakes,

Can the wild Water-lily restore!

What landscapes I read in the Primrose's looks, And what pictures of pebbled and minnowy brooks, In the Vetches that tangled their shore!

Earth's cultureless buds, to my heart ye were dear, Ere the fever of passion, or ague of fear, Had scathed my existence's bloom; 
Once I welcome you more, in life's passionless stage, With the visions of youth to revisit my age. And I wish you to grow on my tomb.

\section{THE HONEYSUCKLE.}

BY THE COUNTESS OF BLESSINGTON.

SEE the Honeysucklc twine

Round this casement:-'tis a shrine

Where the hcart doth incense give,

And the pure affections live

In the mother's gentle breast

By her smiling infant pressed.

Blesséd shrine! dear, blissful home! Source whence happiness doth come! Round by the cheerful hearth we meet All things beauteous-all things sweetEvery solace of man's life, Mother-daughter-sister-wife.

England, isle of free and brave, Circled by the Atlantic wave!

Though we seek the fairest land That the south wind ever fanned,

Yet we cannot hope to see Homes so holy as in thee.

As the tortoise turns its head Towards its native ocean-bed, Howsoever far it be

From its own belovéd sea, Thus, dear Albion, evermore Do we turn to seck thy shore! 


\section{'TO 'THE PASSION-FLOWER,}

BY BERNARD BARTON.

IF Superstition's baneful art

First gave thy mystic name,

Reason, I trust, would steel my heart

Against its groundless claim.

But if, in fancy's pensive hour,

By grateful feelings stirred,

Her fond imaginative power

That name at first conferred-

Though lightly truth her flights may prize,

By wild vagary clriven,

For once their blameless exercise

May surely be forgiven.

We roam the seas-give new-found isles

Some king's or conqueror's name :

We rear on earth triumplant piles

As mecds of earthly fame:-

We soar to heaven; and to outlive

Our life's contracted span,

Unto the glorious stars we give

The names of mortal man:

'Then may not one poor flow'ret's bloom The holier memory share

Of Him who, to avert our doom, Vouchsafed our sins to bear?

God dwelleth not in temples reared

By work of human hands,

Yet shrines august, by men revered, Are found in Christian lands. 
And may not e'en a simple flower

Proclaim His glorious praise, Whose fiat only had the powcr Its form from earth to raise?

Then frecly let thy blossom ope Its bcautics - to recall

A scene which bids the humble hope In Him who died for all!

\section{THE LILY OF THE VALLEY.}

\section{BY BISHOP MANT.}

FAIR flower, that, lapt in lowly glade, Dost hide beneath the greenwood shade,

Than whom the vernal gale None fairer wakes, on bank or spray, Our England's Lily of the May, Our Lily of the Vale!

Art thou that "Lily of the ficld," Which, when the Saviour souglit to shield

The heart from blank despair, He showed to our mistrustful kind, An emblem of the thoughtful mind, Of God's paternal carc?

Not this, I trow; for brighter shine To the warm skies of Palestine Those children of the East :

There, whicn mild autumn's early rain

Descends on parched Esdrela's plain And Tabor's oak-girt crest, k 


\section{The Poetry of Flowers.}

More frequent than the host of night, Those earth-born stars, as sages write, Their brilliant discs unfold;

Fit symbol of imperial state,

Their sceptre-seeming forms elate, And crowns of burnished gold.

But not the less, sweet spring-tide's flower,

Dost thou display the Maker's power, His skill and handiwork ;

Our western valleys' humbler child, Where, in green nook of woodland wild, Thy modest blossoms lurk.

What though nor care nor art be thine, The loom to ply, the thread to twine, Yet born to bloom and fade, Thee to a lovelier robe arrays, Than, e'en in Israel's brightest days, Her wealthiest kings arrayed.

Of thy twin-leaves the embowered screen, Which wraps thee in thy shroud of green,

Thy Eden-breathing smell ;

Thy arched and purple-vested stem, Whence pendent many a pearly gem,

Displays a milk-white bell ;

Instinct with life thy fibrous root,

Which sends from earth the ascending shoot. As rising from the dead, And fills thy veins with verdant juice, Charged thy fair blossoms to produce, And berries scarlet red; The triple cell, the twofold seed, A ceaseless treasure-house decreed, Whence aye thy race may grow, 
As from creation they have grown,

While Spring shall weave her flowery erown,

Or vernal breezes blow;

Who forms thee thus, with unscen hand?

Who at ereation gave eommand,

And willed thee thus to be ;

And keeps thee still in being, through

Age after age revolving? Who

But the great God is He?

Ommipotent, to work His will ;

Wise, who contrives each part to fill

The post to each assigned ;

Still provident with sleepless care,

To keep ; to make thee sweet and fair

For man's enjoyment-kind!

"There is no God," the senseless say :-

"O God! why east'st thou us away?"

Of feeble faith and frail,

The mourner breathes his anxious thought ;

By thee a better lesson taught,

Sweet Lily of the Vale!

Yes, He who made and fosters thee,

In Reason's eye perforee must be

Of majesty divine;

Nor deems she that His guardian care

Will He in man's support forbear,

Who thus provides for thine. 


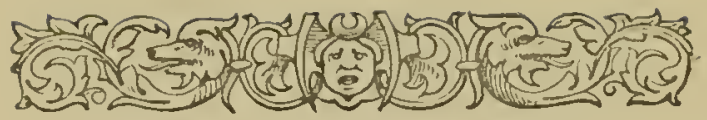

\section{THE LANGUAGE OF FLOWERS.}

\section{PART FIRST.}
Ahecedary
- Volubility.
Abatina .
- Fickleness.
Acacia
Acacia, Rose or Whitc
- Friendship.
Acacia, Yellow
- Elegance.
Acanthus .
- Secret Love.
Acalia
Achillea Millefolia
Achimenes Cupreata
Aconitc (Wolfsbanc)
Aconite, Crowfoot .
Adonis, Flos
African Marigold
The Fine Arts. Artifice.
- Temperance.
- Var.
- Such worth is rare.
- Misanthropy.
- Lustre.
- Painful recollections.
- Vulgar minds.
Agnus Castus .
Agrimony
Almond (Common).
Almond (Flowering)
Almond, I.aurcl .
Allspice
Aloe
Althea Frutcx
Mallow) . Alyssum (Sweet)
- Coldness. Indifference.
- Thankfulness. Gratitude.
- Stupidity. Indiscretion.
- Hope.
- Perfidy.
- Compassion.
- Gricf.
- Persuasion.
- Worth beyond beauty. 


\begin{tabular}{|c|c|c|c|}
\hline & \multirow{7}{*}{$\begin{array}{l}\text { - Unfading love. } \\
\text { - Foppery. Affectation. } \\
\text { - Pride. Splendid beauty. } \\
\text { - Love returned. } \\
\text { - Divine beauty. } \\
\text { - Patriotism. } \\
\text { - Matrimony. } \\
\text { - Welcome to a stranger. } \\
\text { Cheerfulness in old ase. }\end{array}$} \\
\hline \multicolumn{2}{|c|}{$\left(\begin{array}{l}\text { Globe) } \\
\text { Cockscoinb) }\end{array}\right.$} & & \\
\hline & & & \\
\hline W & slip & & \\
\hline & & . & \\
\hline & & $\bullet$ & \\
\hline \multicolumn{2}{|c|}{ herican Starwort } & 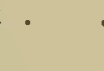 & \\
\hline \multirow{4}{*}{\multicolumn{3}{|c|}{$\begin{array}{l}\text { Amethyst } \\
\text { Andromeda } \\
\text { Anemone (Zephyr Flower) } \\
\text { Anemone (Garden) }\end{array}$}} & - Admiration. \\
\hline & & & c) Set \\
\hline & & & \\
\hline & & & \\
\hline \multirow{5}{*}{\multicolumn{2}{|c|}{$\begin{array}{l}\text { Angelica } \\
\text { Angrec } \\
\text { Apricot (Blossom) } \\
\text { Apple } \\
\text { Apple (Blossom) } \\
\text { Apple, Thorn } \\
\text { Apocynum (Dogsb }\end{array}$}} & & \\
\hline & & $\cdot$ & \\
\hline & & & \\
\hline & & & \\
\hline & & & charm \\
\hline \multicolumn{2}{|c|}{$\begin{array}{l}\text { Arbor Vitæ } \\
\text { Arum (Wake Robin }\end{array}$} & & $\begin{array}{l}i n g \text { fr } \\
\text { or me. }\end{array}$ \\
\hline \multicolumn{3}{|c|}{$\begin{array}{l}\text { rum (Wake Robin) } \\
\text { sh-1caved Trumpet Flowe } \\
\text { sh, Mountain }\end{array}$} & \\
\hline \multirow{5}{*}{$\begin{array}{l}\text { h, Mountain } \\
\text { h Tree. } \\
\text { pen Tree } \\
\text { ter (China) } \\
\text { phodel. }\end{array}$} & & & 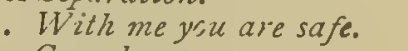 \\
\hline & & & \\
\hline & & & \\
\hline & & & \\
\hline \multirow{3}{*}{\multicolumn{2}{|c|}{, Scarlet }} & & \\
\hline & & & \\
\hline & & & \\
\hline \multicolumn{2}{|l|}{. } & & \\
\hline
\end{tabular}


Baehelor's Buttons .

Balm

Balm, Gentle

Balm of Gilead

Balsam, Red .

Balsam, Yellow

Barberry .

Basil

Bay Leaf.

Bay (Rose) Rhododendron Danger. Bezuare.

Bay Tree .

Bay Wreath

Bearcled Crepis

Beeeh Tree

Bee Orehis

Bee Ophrys

Begonia

Belladonna

Bell Flower, Pyramidal

Bell llower (small white) Gratitude.

Belvedere.

Betony

Bilberry

Bindweed, Great

Bindweed, Small

Birel

Birdsfoot, Trefoil

Bittersweet; Nightshade. Truth.

Blaek Poplar . . Courage.

Blaekthorn . . Dificulty.

Bladder Nut Tree : Frivolity. Amusement.

Bluebottle (Centaury) . Delicacy.

Bluebell .

I declare against you.

- Surprise.

- Treachery.

- Insinuation.

- Revenge.

- Constancy. Sorrowful
- Celibacy.

- Sympathy.

- Pleasantry.

- Cure. lielief.

- Impatient resolves.

- Impatience.

- Sharpness of temper.

- Hatred.

- Giory.

- Reward of merit.

- Protection.

- Prosperity.

- Industry.

- Error.

- Deformity.

. Silence. Hush!

- Humility.

- Meekness. regret. 
Blue-flowered Greek Valerian

Bonus Henricus

Borage

Box Tree.

Bramble .

Branch of Currants . Branch of Thorns . Bridal Rose

Broom

Browallia Jamisonii .

Buckbean

Bud of White Rose :

Buglos

Bulrush

Bundle of Reeds,

their Panicles

Burdock .

Bur .

Buttercup (Kingcup)

Butterfly Orchis

Butterfly Wced

Cabbage .

Cacalia .

Cactus

Calla AEthiopica

Calceolaria

Calycanthus
- Rupture.

- Goodness.

- Btuntness.

- Stoicism.

- Lowdiness. Envy. Remorse.

- You please all.

- Severity. Rigour.

- Happy love.

Humility. Neatness.

- Could you bear poverty?

- Calm repose.

- Heart ignorance of love,

- Falschood.

- Indiscretion. Docility.

with

- Music.

- Importunity. Touch me not.

- Rudeness. You wearyme.

- Ingratitude. Childishness.

- Gaiety.

- Let me go.

- Profit.

- Adulation.

- Warmin.

- Magnificent bcauty.

- I offer you pecuninry assistance, or $I$ ofjer you my fortunc.

Benevolence. 
Camellia Japonica, Red . Unpretending excellence.

Camellia Japonica, White Perfected loveliness.

Camomile

Campanula Pyramida

Canary Grass .

Candytuft

Canterbury Bell

Cape Jasmine .

Cardamine

Carnation, Deep Red

Carnation, Striped .

Carnation, Yellow

Cardinal Flower

Catchfly

Catchfly, Red .

Catchfly, White

Cattleya

Cattleya Pineli

Cedar

Cedar of Lebanon

Cedar Leaf

Celandine (Lesser)

Cereus (Creeping)

Centaury .

Champignon

Checkered Fritillary

Cherry Tree, White

Cherry Tree, White

Chestnut Tree .

Chinese Primrose

Chickweed

Chicory .

China Aster

China Aster, Double
- Energy in adversity.

- Aspiring.

- Perseverance.

- Indifference.

- Acknowledgment.

- I am too happy.

- Paternal error.

- Alas / for my poor heart.

- Refusal.

- Disdain.

- Distinction.

- Srare.

- Youthful love.

- Betrayed.

- Mature charms.

- Matronly grace.

- Strength.

- Incorruptible.

- I live for thee.

- Foys to come.

- Modest genius.

- Delicacy.

- Suspicion.

- Persecution.

- Good education.

- Deception.

- Do me justice.

- Lasting love.

- Rendezvous.

- Frugality.

- Variety.

- I partakeyour sentiments. 
China Aster, Single . China or Indian Pink China Rose Chinese Chrysanthemum

Chorozema Varium . Christmas Rose Chrysanthemum, Red Clirysanthemum, White Chrysanthemum, Yellow Cineraria . Cinquefoil Circæa

Cistus, or Rock Rose Cistus, Gum . Citron Clarkia

Clematis Clematis, Evergreen Clianthus

\section{Clotbur}

Clover, Four-leaved .

Clover, Red

Clover, White .

Cloves

Cobæa

Cockscomb Amaranth Colchicum, or Meadow Saffron. . . . Coltsfoot : : Columbine Columbine, Purple.
- I will think of it.

- Aversion.

- Beauty always new.

Cheerfulness under adversity.

- You have many lovers.

- Relieve my anxiety.

- I love.

- Truth.

- Slighted love.

- Always delightful.

- Maternal affection.

- Spell.

- Popular favour.

- I shall die to-morrow.

- Ill-natured beauty.

- The variety of your conversation delights me. - Mental beauty.

- Poverty.

-Worldliness. Self-seek. ing.

- Rudeness. Pertinacity.

Be mine.

Industry.

- Think of me.

- Dignity.

- Gossip.

Affectation. Singularity
My best days are past.

- Fustice sizall be done.

- Folly.

- Resolved to win. 
Columbine, Red . . Anxious and trembling.

Convolvulus Bonds.

Convolvulus, Biue (Minor) Repose. Night.

Convolvulus, Major . Extinguished hopes.

Convolvulus, Pink .

- Worth sustained by judzcious, tender affection.

Corchorus

Coreopsis

Coreopsis Arkansa

Coriander

Corn

Corn, Broken .

Corn Straw

Corn Bottle

Corn Cockle

Cornel Tree

Coronella

Cosmelia Subra

Cowslip .

Cowslip, American .

Crab (Blossom)

Cranberry

Creeping Cereus

Cress

Crocus

Crocus, Spring

Crocus, Saffron

Crown, Imperial

Crowsbill

Crowfoot .

Crowfoot (Aconite-leaved) Lustre.

Cuckoo plant . . Ardour.

Cudweed, American
- Imputient of absence.

- Always cheerfut.

- Love at first sight.

- Hidden worth.

- Riches.

- Quarrel.

- Agreement.

- Delicacy.

- Gentility.

- Duration.

- Successcrown yourwishes.

- The charm of a blush.

- Pensiveness.

Winning grace.

- Divine beauty.

- Ill nature.

- Cure for heartache.

- Horror.

- Stability.

- Abuse not.

- Youthful gladness.

- Mirth.

- Majesty. Power.

- Enzy.

Ingratitude.

- Unceasing remembrance. 
Currant

Cuscuta

Cyclamen

Cypress

DAFFODIL

Dahlia

Daisy

Daisy, Garden .

Daisy, Michaelmas

Daisy, Parti-coloured

Daisy, Wild

Damask Rose .

Dandelion

Daphne

Daphne Odora

Darnel

Dead Leaves

Deadly Nightshade .

Dew Plant

Dianthus .

Diosma
Thy frown will kill me. Meanness.

- Diffidence.

- Death. Mourning.

- Regard.

- Instability.

- Innocence.

- I share your sentiments.

- Farewell.

- Beauty.

- I will think of it.

- Brilliant complexion.

- Rustic oracle.

- Glory. Immortality.

- Painting the Lily.

- Vice.

- Sadness.

- Falsehood.

- A serenade.

- Make haste.

- Your simple elegance charms me.

Dipteracanthus Speetabilis Fortitude.

Diplademia Crassinoda. You are too bold.

Dittany of Crete . Birth.

Dittany of Crete, White . Passion.

Dock Dodder Thyme .

Dogsbane

Dogwood

Dragon Plant .

Dragonwort

Dried Fiax

EBONY TREE.

Lchites Atropurpurea
- Patience.

- Baseness.

- Deceit. Falsehood.

- Durability.

- Snare.

- Horror.

- Utility.

- Blackness.

- Be warned in time. 
156 The Language of Flowers.

Eglantine (Sweet-brier) . Poetry. I wound to heal. Elder . . . Zcalousness.

Elm . . Dignity.

Enchanter's Nightshade . Witchcraft. Sorcery. Endive

Escholzia. . . . Do not refuse me.

- Frugality.

Eupatorium . . Delay.

Everflowering Candytuft . Indifference.

Evergreen Clematis. . Poverty.

Evergreen Thorn . Solace in adversity.

Everlasting . . Never-ceasing remem-

Everlasting Pea . . Lasting pleasure.

FENNEL . . Worthy of all praise.

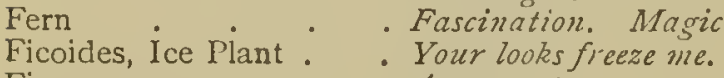
Strength.

Fig .

Fig Marigold : : : Idlencss.

Fig Tree . . . Prolific.

Filbert . . . Reconciliation.

Fir . . . . Time.

Fir Tree : : Elevation.

Flax . . Domestic industry. Fate.

Flax-leaved Golden-locks Tardiness.

Fleur-de-lis . . Fiame. I burn.

Fleur-de-Luce : . Fire.

Flowering Fern : Reverie.

Flowering Recd . Confidence in Heaven.

Flower-of-an-hour . Delicate beanty.

Fly Orchis . . . Error.

Flytrap . . Deceit.

Fool's Parsley . . . Sillinesss.

Forget-me-not . . True love.

Foxglove. . . Insincerity. 
Foxtail Grass

Franciscea Latifolia . French Honeysuckle

French Marigold

French Willow

Frog Ophrys .

Fuller's Teasel .

Fumitory .

Fuschia, Scarlet

Furze, or Gorse

GARDEN ANEMONE

Garden Chervil

Garden Daisy .

Garden Marigold

Gardcn Sage

Garland of Roses

Gardenia .

Germander Spcedwell

Geranium, Dark

Geranium, Horse-shoe

$$
\text { Leaf }
$$

Geranium, Ivy .

Geranium, Lemon.

Geranium, Nutmeg .

Geranium, Oak-leavcd

Geranium, Pencilled

Geranium, Rosc-scentcd

Geranium, Scarlet .

Geranium, Silver-leaved

Geranium, Wild

Gillyflower

Gladioli

Glory Flower

Goat's Rue

Golden Rod
- Sporting.

- Beware of false firiends.

- Rustic beauty.

- Jealousy.

- Bravery and humanity.

- Disgust.

- Misanthropy.

- Spleen.

- Taste.

- Love for all seasons.

- Forsaken.

- Sincerity.

- I partakc yoursentiments.

- Uneasiness.

- Estcem.

- Reward of virtue.

- Refunement.

- Facility.

- Melancholy.

- Stupidity.

- Bridal favour.

- Unexpected Mecting.

- Expected Mectins.

- True friendship.

- Ingenuity.

- Preference.

- Comforting.

- Recall.

- Steadfast piety.

- Bonds of affection.

Ready armed.

- Glorious beauty.

Reason.

- Precaution. 
Gooscberry . . Anticipation.

Gourd . . Extent. Bulk.

Grammanthus Chloraflora Your temper is too hasty. Grape, Wild . . . Charity.

Grass . . . Submission. Utility.

Guelder Rose . . Winter. Age.

HAND Flower TREE - Warning.

Harebell • • . Submission. Grief.

Hawkweed . . . Quicksightedness.

Hawthorn . . Hope.

Hazel . . . Reconciliation.

Heart's-ease, or Pansy . Thoughts.

Heath . . . Solitude.

Helenium : $\quad$. Tears.

Heliotrope . Devotion, ar I turn to thee.

Hellebore

Helmet Flower (Monkshood)

. Knight-errantry.

Hemlock . . . . You will be my death.

Hemp . . . Fate.

Henbane . . . Imperfection.

Hepatica . . . Confidence.

Hibiscus . . . Delicate beauty.

Holly : : . Foresight.

Holly Herb : . Enchantment.

Hollyhock . . Ambition. Fecundity.

Honcsty. . Honesty.

Honey Flower. - Love sweet and secret.

Honeysuckle . . . Generous and devoted

Ioneysuckle (Coral) . The colour of my fate.

Honeysuckle (French) . Rustic beauty.

Hop

Holnbeam

- Injustice.

- Ornament. 


\section{The Language of Flowers.}

I Iorse Chestnut

I Iortensia

IIouseleek

Iloustonia

Ioya

Hoyabella

Humble Plant .

Hundred-leaved Rose

Hyacinth .

Hyacinth, Purple

Hyacinth, White

Hydrangea

Hyssop

ICELAND MOSS

Ice Plant .

Inbricata

Imperial Montague.

Indian Cress

Indian Jasmine

Indian Pink (Double)

Indian Plum

Iris

Iris, German

Ivy . . . . Friendship. Marriage.

Ivy, Sprig of, with Tendrils Assiduous to please.

JACOB'S LADDER . . Come down.

Japan Rose .

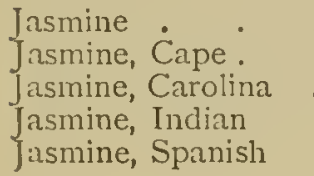

- Luxury.

- You are cold.

- Vivacity. Domestic in. dustry.

Content.

- Scuipture.

- Contentmint.

- Despondency.

- Dignity of mind.

- Sport. Game. Play.

- Sorrowfull.

- Unobtrusive loveliness.

- A boaster.

- Cleanliness.

- Health.

- Your looks freeze me.

- Uprightness. Sentements of honour.

- Power.

- Warlike trophy.

a) Attachment.

- Always lovely.

- Privation.

- Message.

- Flame.

- Beauty is your only attraction.

- Amiability.

- Transport of joy

- Separation.

- I attach myself to you.

- Sensuality. 
Jasmine, Yellow Jonquil

Judas Tree

Juniper .

Justicia .

KENNEDIA

Kingcups

LABURNUM

Lady's Slipper .

Lagerstræmia, Indian

Lantana .

Lapageria Rosea .

Larch

Larkspur .

Larkspur, Pink

Larkspur, Purple .

Laurel

Laurel, Common, in flower Perfidy.

Laurel, Ground

Laurel, Mountain

Laurel-leaved Magnolia

Laurestina

Lavender .

Leaves (dead)

Lemon

Lemon Blossoms

Leschcnaultia Splendens

Lettuce

Lichen

Lilac, Field

Lilac, Purple

Lilac, White

Lily, Day
- Grace and elegance.

- I desire a return of affection.

- Unoelief. Betrayal.

- Succour. Protection.

- The perfection of female loveliness.

- Mental beauty.

- Desire of riches.

- Pensive Beauty.

- IVin me and wear me.

- Eloquence.

- Rigour.

- There isnounalloyedgood.

- Audacity. Boldness.

- Lightness. Levity.

- Fickleness.

- Hauglitiness.

- Glory.

- Perseverance.

- Ambition.

- Dignity.

- A token.

- Distrust.

- Melancholy.

- Zest.

- Fidelity in love.

You are charming.

- Cold-heartedness.

- Dejection. Solitude.

- Humility.

- First emotions of love.

- Youthful innocence.

- Coquetry. 
Lily, Imperial .

Lily, White

Lily, Yellow

Lily of the Valley

Linden or Lime Trees

Lint

Live Oak .

Liverwort

Liquorice, Wild

Lobelia

Loeust Tree

Locust Tree (green)

London Pride .

Lote Tree

Lotus

Lotus Flower

Lotus Leaf

Love in a Mist

Love lies Bleeding

Lueern

\section{Lupine}

MADDER .

Magnolia

Magnolia, Swamp

Mallow

Mallow, Marsh

Mallow, Syrian

Mallow, Venetian

Malon Creeana

Manehineal Tree

Mandrake

Maple

Marianthus
- Majesty.

- Purity. Srueetness.

- Gaiety.

- Return of happiness. Un. conscious sweetness.

- Conjugal love.

- I feel my obligations.

- Liberty.

- Confidence.

- I declare against you.

- Malevolence.

- Elegance.

- Affection beyond the grave.

- Frivolity.

- Concord.

- Eloquence.

- Estranged love.

- Recantation.

- Perplexity.

- Hopeless, not heartless.

- Life.

- Voraciousness.

- Calumny.

- Love of Natare.

- Perseverance.

- Mildness.

- Beneficence.

- Consumed by love.

- Delicate beauty.

- Will you share my fortunes?

- Falsehood.

- Horror.

- Reserve.

- Hope for better days. 
Marigold .

Marigold, African Marigold, French .

Marigold, Prophetic

Marigold and Cypress

Marjoram

Marvel of Peru

Meadow Lychnis

Meadow Saffron

Meadowsweet .

Mercury .

Mesembryanthemum

Mezereon

Michaelmas Daisy

Mignonette

Milfoil

Milkvetch

Milkwort
Mimosa (Sensitive Plant) Sensitrveness.

Mint

Mistletoe .

Mitraria Coccinea

Mock Orange .

Monarda Amplexicaulis

Monkshood

Monkshood (Helmet

Flower.

Moonwort

Morning Glory

Moss

Mosses

Mossy Saxifrage .
- Grief.

- Vulgar minds.

- Fealousy.

- Prediction.

- Despair.

- Blushes.

- Timidity.

- Wit.

- My best days are past.

- Uselessness.

- Goodness.

- Idleness.

- Desire to please.

- Afterthougrit.

- Your qualities surpass your charms.

- War.

- Your presence softelis my pains.

Virtue.

- I surmount difficulties.

- Indolence. Dulness.

- Counterfeit.

- Your whims are quite unbearable.

- A deadly foc is near. Chivalry. Knight-erran try.

- Forgetfulness.

- Affectution.

- Maternal lovs.

- Ennui.

- Affection. 
Motherwort . . Concealed love.

Mountain Ash. . Prudence.

Mourning Bride . . I have lost all.

Mouse-earcd Chickweed . Ingenuous simplicity.

Mouse-eared Scorpion Grass

Moving Plant .

Mudwort .

Mulberry Tree (Black)

Mulberry Tree (White)

Mushroom

- Forget me not.

- Agitation.

- Mappiness. Tranquillity.

- I shall not survive you.

- Wisdom.

- Suspicion, or I can't entirely trust you.

Musk Plant

Mustard Seed :

Myrobalan

Myrrh

Myrtle :

NARCISSUS

Nasturtiun:

Nemophila. Sommon Stinging Success everywher You are spiteful.

Nettle, Burning

Nettle Tree Night-blooming Cereus

Night Convolvulus

Nightshacle

OAK LEAVES.

Oak 'Trice

Oak (White)

Oats

Oleander .

Olive

Orange Blossomis

Orange Flowers

- Slander.

- Conceit.

Transient beauty.

- Night.

- Falschood.

- Bravery.

- Hospitality.

- Independence.

- The woitching soul of

- Beware.

- Peace.

- Your purity equals your loveliness. - Chastity. Bridul festi- 
Orange Trec .

Orchis

Osier

Osmunda

Ox-eye .

PALM

Pansy

Parsley

Pasque Flower

Passion Flower (reversed)

Passion Flower (erect)

Patience Dock .

Pea, Everlasting

Pea, Sweet

Peach

Peach Blossom

Pear

Pear Tree

Penstemon Azureum

Pennyroyal

Peony

Peppermint

Periwinkle, Blue

Periwinkle, White

Persicaria

Persimon .

Pcruvian Heliotrope

Petunia

Pheasant's Eye

Phlox

Pigeon Berry

Pimpernel

Pine
- Generosity.

- A belle.

- Frankness.

- Dreams.

- Patience.

- Victory.

- Thoughts.

- Festivity.

- You have no claims.

) Religious superstition.

- Faith.

- Patience.

- Lasting pleasure.

- Depariure.

- Your qualities, like jour charms, are unequalled. - I ain your captive.

- Afjection.

- Comfort.

- High-bred.

- Flee away.

- Shame. Bashfulness.

- Warmih of fieling.

- Early Friendship.

- Pleasures of memory.

- Restoration.

- Bury me amid Nature's beauties.

- Devotion.

- Your presence soothes mz.

- Remembrance.

- Unanimity.

- Indifference.

- Change. Assignation.

- Pity. 
Pine-apple
Pine, Pitch
Pine, Spruce :
Pink,
Pink, Carnation
Pink, Indian, Double
Pink, Indian, Single
Pink, Mountain
Pink, Red, Double
Pink, Single
Pink, Variegated
Pink, White :
Plantain :
Plane Tree :
Plum, Indian :
Plum Tree
Plum, Wild :

Plumbago Larpenta Polyanthus

Pclyanthus, Crimson Polyanthus, Lilac . Pomegranate Pomegranate Flower Poor Robin

Poplar, Black . Poplar, White . Poppy, Red Poppy, Scarlet . Poppy, White . Potato

Yotentilla

Prickly Pear Pride of China . Primrose.
- You are perfect.

- Philosophy.

- Hope in adversity.

- Boldness.

- Woman's love.

- Alvuays lovely.

- Aversion.

- Aspiring.

- Pure and ardent love.

- Pure love.

- Refusal.

- Ingeniousness. Talent.

-White man's footsteps.

- Genius.

- Privation.

- Fidelity.

- Independence.

- Holy wishes.

- Pride of riches.

- The heart's mystery.

- Confidence.

- Foolishness.

- Mature elegance.

- Compensation or an equivalent.

- Courage.

- Time.

- Consolation.

- Fantastic extravagance.

- Sleep. My bane.

- Benevolence. [esteen.

- I reckon on, at least, your

- Satire.

- Dissension.

- Early youth and sadness. 
Primrose, Evening .

Privet

Purple Clover .

I'yrus Japonica

QUAKING GRASS

Qucen's Roekct

Quince

RAGGED ROBIN

Ranunculus

Ranunculus, Wild

Raspberry

Ray Grass

Red Catchfly

Recd

Rhododendron

Rhubarb .

Rocket .

Rose

Rose, Austrian

Rose, Bridal .

Rose, Cabbage

Rose, Campion

Rose, Carolina

Rose, China .

Rose, Christmas

Rose, Daily

Rose, Damask.

Rose, Deep Red

Rosc, Dog

Rose, Guelder .

Rose, Hundred-leaved

Rose, Japan . .
- Inconstancy.

- Prohibition.

- Provident.

- Fairies Fire.

- Agitation.

- You are the queen of coquettes. Fashion.

Temptation.

- Wit.

- You are radiant with charins.

- Ingratitude.

- Remorse.

- Vice.

- Youthful love.

- Complaisance. Music. Danger.

- Advice.

- Rivalry.

- Love. - Tlovely.

- Happy love.

- Ambassador of love.

- Only deserve my love.

- Love is dangerous.

- Beauty always new.

- Tranquillise my anxiety.

- Thy smile I aspire to.

- Brilliant complexion.

- Bashful shamie.

- Pleasure and pain.

- Winter. Age.

- Pride.

- Beauty is your only attraction. 
Rose, Maiden Blush

Rose, Montiflora

Rose, Mundi .

Rose, Musk

Rose, Musk, Cluster

Rose, Single

Rose, Thornless

Rose, Unique .

Rose, White

Rose, Yellow
If you love me you will find it out.

Grace.

- Variety.

- Capricious beauty.

Charming.

- Simplicity.

- Early attachment.

- Call me not beautiful.

- I am worthy of you.

- Jealousy.

Rose, York and Lancaster War.

Rose, Full-blown, placed over two Buds

Rose, White and Red together

Roses, Crown of

Rosebud, Red .

Rosebud, White

Rosebud, Moss

Rosebud (Rhododendron) Beware. Danger.

Rosemary

Rudbeekia

Rue .

Rush

Rye Grass

SAFFRON

Saffron Crocus.

Saffron, Meadow

Sage

Sage, Garden

Sainfoin

Saint John's Wort

Dalvia, Blue

Salvia. Red
Secrecy.

Reward of virtue.

Pure and lovely.

- Girlhood.

Confession of love.

Remembrance.

- Fustice.

Disdain.

- Docility.

- Changeable disposition.

- Beware of excess.

- Mirth.

- My happiest days are fast.

- Domestic virtue.

- Esteem.

- Agitation.

- Animosity.

- Energy.
- Unity.

- Wisdom. 
Saxifrage, Mossy

Scabious .

Scabious, Swcet

Scarlet Lychnis

Schinus

Scotch Fir

Sensitive Plant

Senvy

Shamrock

Shepherd's Purse

Siphocampylos

Snakesfoot

Snapdragon

Snowball.

Snowdrop

Sorrel

Sorrel, Wood :

Southernwood .

Spanish Jasmine

Spearmint

Speedwell

Speedwell, Germander

Speedwell, Spiked .

Spider Ophrys

Spiderwort

Spiked Willow Herb

Spindle Tree

Star of Bethlehem

Starwort .

Starwort, American :

Stephanotis

Stock

Stock, Ten-week :
- Affection.

- Unfortunate love.

- Widowhooil.

Sunbeaming yes.

Religious enthusiasm.

- Elevation.

- Sensibility.

- Indifference.

- Light-heartedness.

- I offer you my all.

- Resolved to be noticed.

- Horror.

- Presumption, also "No."

- Bound.

- Hope.

- Affection.

- Foy.

- Jest.

Sensuality.

- Warmth of sentiment.

- Female fidelity.

- Facility.

- Sembiance.

- Adroitness.

- Esteem, not love.

- Pretension.

- Yourcharmsare engraves. on my heart.

- Purity.

- Afterthought.

- Cheerfulness in old age.

- Will you accompany me to the East?

- Lasting beauty.

- Promptness. 
Stonecrop

Straw, Broken .

Straw, Whole .

Strawberry Blossoms

Sultan, Lilac

Sultan, White .

Sultan, Yellow .

Sumach, Venice

Sunflower

Swallow-wort

Sweet Basil

Sweetbrier, American

Sweetbrier, European

Sweetbrier, Yellow.

Sweet Pea

Sweet Sultan

Sweet William .

Sycamore

Syringa

Syringa, Carolina

TAMARISK

Tansy (Wild)

Teasel

Tendrils of Climbing

Plants .

Thistle, Common .

Thistle, Fuller's

Thistle, Scotch

Thorn Apple

Thorn, Branch of

Thrift

Throatwort

Thyme

Tiger Flower
- Tranquillity.

- Rupture of a contract.

- Union.

- Foresight.

- I forgive you.

- Srueetness.

- Contempt.

. Splendour.

- Haughtiness.

- Curc for heartache.

- Good wishes.

- Simplicity.

- I wound to heal.

- Decrease of love.

- Delicate pleasures.

- Felicity.

- Gallantry.

- Curiosity.

- Memory.

- Disappointment.

- Crime.

- I declarewar against you.

- Misanthropy.

- Ties.

- Austerity.

- Misanthropy.

- Retaliation.

- Deceitful charms.

- Severity.

- Sympathy.

- Neglected bcauty.

- Activity or courage.

- For once may pride be. friend me. 
Traveller's Joy .

Tree of Life .

Trefoil

Tremella Nestoe

Trillium Pietum

Triptilion Spinosum

Trumpet Flower

Tuberose .

Tulip, Red

Tulip, Variegated

Tulip, Yellow .

Turnip .

Tussilage (Sweet-scented)
Truffle

- Safety.

- Old age.

- Revenge.

- Resistance.

- Modest beauty.

- Beprudent.

- Surprise.

- Fame.

- Dangerous pleasures.

- Declaration of love.

- Beautiful eyes.

- Hopeless love.

- Charity.

i) Fustice shall be done you. VALERIAN

Valerian, Greek

Veniee Sumaeh

Venus's Car

Venus's Looking-glass

Venus's Trap .

Verbena, Pink

Verbena, Scarlet

Verbena, White

Vernal Grass

Veronica .

Vervain .

Vine

Violet, Blue

Violet, Sweet

Violet, Yellow .

Virginia Creeper

Virgin's Bower
- An accommodating dis. position.

- Rupture.

- Intellectual excellence.

- Fly with me.

- Flattery.

- Deceit.

- Family union.

- Unite against cvil, or Church unity.

- Pray for me.

- Poor, but happy.

- Fidelity.

- Enchantment.

- Intoxication.

- Faithfulness.

- Modesty.

- Rural happiness.

- I cling to you both in sunshine and shade. - Filial love. 
Viscaria Oculata

Volkamenia

WALNUT .

Wallfower

Watcher by th

Water Lily

Water Melon

Wax Plant

Wheat Stock

Whin

White Jasmine

White Lily

White Mullein .

White Oak

White P'ink

White Poplar

White Rose (dried).

Whortlebcrry .

Willow, Creeping

Willow, Water

Willow, Weeping

Willow Herb .

Willow, French

Winter Cherry

Wisteria .

Witch Hazel .

Woodbine

Wood Sorrel

Wormwood .

XANTHIUM

Xeranthemum .

YEW

ZePHyr Flower

Zinnia
- Will you dance with me?

- May you be happy.

- Intellect. Stratagen.

- Fidelity in adversity.
Wayside Never despair.

- Purity of heart.

- Bulkiness.

- Susceptibility.

- Riches.

- Anger.

- Amiability.

- Purity and modesty.

- Good-nature.

- Independence.

- Talent.

- Tinze.

- Death preferable lo loss of innocence.

- Treason.

- Love forsaken.

- Freedom.

- Mourning.

- Pretension.

- Bravery and humanity.

- Deception.

- Welcome, fair stranser.

- A spell.

- Fraternal love.

- Maternal tenderness.

- Absence.

Rudeness. Pertinacity.

- Checrfulness underadver-

- Sorrozo.

- Expectation.

- Thoughtsof absentfriends 


\section{PART SECOND.}

ABSENCE .

Abuse not

- Wormwood.

Acknowledgment

Activity, or Courage

A deadly foe is near

Admiration

Adroitness

Adulation

Advice .

Affection .

Affection beyond the grave Green Locust.

Affection, Maternal . Affectation

Afterthought Agreement

Age .

Agitation

Alas! for my poor heart Always cheerful Always lovely . Always delightful Ambassador of love. Amiability Anger

Animosity

Anticipation

Anxious and trembling Ardour, Zeal . Argument Arts, or Artifice
- Crocus.

- Canterbury Be!l.

- Thyme.

- Monkshood.

- Amethyst.

- Spider Ophrys.

- Cacalia.

- Rhubarb.

- Mossy Saxifrage. Pear. Sorrel.

Cinquefoil.

- Cockscomb Amaranth. Morning Glory.

- Starwort. China Aster. - Straze.

- Guelder Rose.

- Moving Plant. Sainfoin.

- Deep Red Carnation.

- Coreopsis.

- Indian Pink (double).

- Cineraria.

- Cabbage Rose.

- Jasmine.

- Whin, or Gorse.

- St. Fohn's Wort.

"Goosebcrry.

- Red Columbine.

- Cuckoo Plant. Arum.

- Fig.

- Acanthus. 
Assiduous to plense. Assignation Attachment Audacity . Avarice : Aversion . Baseness Bashfulness Bashful shame . Be prudent

Be warned in time.

Beautiful eyes .

Beauty

Beauty always new

Beauty, capricious.

Beauty, delicate

Beauty, divine .

Beauty, glorious

Beauty, lasting

Beauty, magnificent

Beauty, mental

Beauty, modest

Beauty, ncglected .

Beauty, pensive

Beauty, rustic .

Bcauty is your only attrac-

tion

Belle

Be mine

Beneficence

Benevolence

Betraycd .

Beware

Beware of a false friend
- Sprig of layzuith tendrils.

- Pimpernel.

- Indian Fasmine.

- Larcla.

- Scarlet Auricula.

- China or Indian Pink.

- Dodder of Thyme.

- Peony.

- Decp Rel Rose.

- Triptilion Spinosum.

- Fichites Atro-purpurea.

- Variegated Tulip.

- Parti-coloured Daisy.

- China Rose.

- Musk Rose.

- Flower of an hour. Hibiscus.

- Amrican Cowslip.

- Glory Flowes.

- Slock.

- Colla Athiopica.

- Clematis.

- Trillium Pictum.

- Throatwort.

- Laburnum.

- Froncla Honeysuckle.
- Fapan Rose.

- Orchis.

- Four-leaved Clover.

- Marshmallozo.

- Potato.

- White Catchfly.

- Oleander.

- Franciscea Latifolis. 
Blackness

Bluntness

Blushes .

Boaster .

Boldness .

Bonds

Bonds of affection

Bravery .

Bravery and humanity

Bridal favour

Brilliant complexion

Bulk me amid Nature's beauties

CALL me not beautiful

Calm repose

Calumny .

Change

Changeable disposition

Charity

Charming

Charms, deceitful .

Cheerfulness in old age

Cheerfulness under adversity

Chivalry .

Cleanliness

Coldheartedness

Coldness .

Colour of my life

Come down

Comfort

Comforting

Compassion

Concealed love
Ebony Tree.

- Borage.

- Marjoram.

- Hydrangea.

- Pink.

- Convolvulus.

- Gillyforver.

- Oak Leaves.

French Willow.

- Ivy Geranium.

- Damask Rose.

- Water Melon. Gourd.
- Persimmon.

- Rose Unique.

- Buckbean.

- Hellebore. Madder.

- Pimpernel.

- Rye Grass.

- Turnip.

- Cluster of Musk Roses.

- Thorn Apple.

- American Starwort.

- Chinese Chrysanthemum.

- Monkshood.

- Hyssop.

- Lettuce.

- Agnus Castus.

- Coral Honcysuckle.

Jacob's Ladder.

- Pear Tree.

- Scarlet Geranium.

Allspice.

- Motherzort. 
Concert :
Concord :
Confession of love
Confidence in heaven

Conjugal love .

Consolation

Constancy

Consumed by love

Contentment

Could you bear poverty

Counterfeit

Courage .

Crimc

Cure

Cure for heartache .

Curiosity .

DANGER

Dangerous pleasures

Death preferable to loss of innocence

Deceit

Deceitful charms

Deccption

Declaration of love

Deformed

Dejection .

Delay

Delicacy .

Desirc to plcase

Despair

Despondency .
- Nettle Tree.

- Lote Tree.

- Moss Rosebud.

- Hepatica. Lilac Polyanthus. Liverwort.

- Flowering Reed.

- Lime or Linden Tree.

- Red Poppy.

- Bluebell.

- Syrian Mallow.

- Hoyabella.

- Brozvallia famisoniz.

- Mock Orange.

- Black Poplar.

- Tamarisk.

- Balm of Gilead.

- Szuallozv-zwort.

- Sycamore.

- Rhododendron Rosebay.

- Tuberose.

Cypress.
- White Rose (dricd).

- Apocynum. Dogsbane. Apple, Thorn.

- White Cherry Tree.

- Red Tulip.

- Begonia.

- Lichen.

- Eupatorium.

- Bluebotile. Contaury.

- Mezercon.

- Cypress.

- Humble Plant. 
r76 The Language of Flowers.

Devotion, or I turn to thee Peruvian Heliotrope.

Difficulty. . . Blackthorn.

Dignity . . . Cloves. Laurel-leaved Magnotia.

Disappointment . Syringa, Carolina.

Disdain . . . Yellozo Carnation. Rue.

Disgust . . . Frog Ophrys.

Dissension . . . Pride of China.

Distinction . . . Cardinal Flower.

Distrust . . . . Lavender.

Divine beauty . . American Cowslip.

Docility . . . . Rush.

Domestic Industry . . Flax.

Domestic virtue . . Sage.

Do not despisc my poverty Shepherd's Purse.

Do not refuse me . . Eschcolzia, or Carrot Flower.

Doubt

Durability

Duration .

EARLY attachment .

Early friendship

Early youth

Elegance .

Elegance and grace .

Elevation .

Eloquence

Enchantment

Energy

Energy in adversity .

Envy

Error

Esteem

Fsteem, not love .

Estranged love
Apricot Blossom.

- Dogruood.

- Cornel Tree.

- Thornless Rose.

- Blue Periwinkle.

- Primruse.

- Locust Tree.

- Yellow fasmine.

- Scotch Fir.

- Indian Lagerstrcemia.

- Holly Herb. Vervian.

- Red Salvia.

- Camomile.

- Bramble.

- Bee Orchis. Fly Orchis.

- Garden Sage.

- Spiderwort.

- Lotus Flower. 
Exeellence

Expectation

Expected meeting

Extent

Extinguished hopes .

FACILITy

Fairies' Firc

Faithfulness

Falsehood

Fame

Family union

Fantastic extravagance

Farewell .

Fascination

Fashion .

Fecundity

Felicity

Fcmale fidelity

Festivity .

Fieklcness

Fidelity

Fidclity in adversity

Fidelity in love

Filial love

Fire .

First emotions of love

Flamc

Flattery

Flee away

Fly with me

Folly

Foolishness

Foresight

Forgetfulness
- Camellia Faponica.

- Anemone. Zephyr Flower.

- Nutmeg Geranium.

- Gourd.

- Major Convolvulus.

- Germander Speedwell.

- Pyrus faponica.

- Blue Violet. Heliotrope.

- Bugloss. Deadly Nightshade. Manchineal Tree.

Tulip.

Pink Verbena.

- Scarlet Poppy.

Michaelmas Daisy.

- Fern.

Queen's Rocket.

Hollyhock.

Sweet Sultan.

Speedruell.

Parsley.

Abatina. Pink Larkspur.

- Veronica. Plum Trec.

- Wallfower.

- Lemon Blossoms.

Virgin's Bower.

- Fleur-de-luce.

- Purple Lilac.

- Fleur-de-lis. Iris.

- Venus's Looking-glass.

Pennyroyal.

- Venus's Car.

- Columbini.

- Ponesranate.

- Holly.

Moonzoort. 
Forget me not .

For onee may pride befriend me

- Forget-me-not.

Forsaken .

Tiger Flower.

Fortitude.

Garden Anemone.

Frankness

Dipteracanthus

Osier.

Fraternal love .

Woodbine.

Freedom .

Freshness

Friendship

Friendship, early .

Friendship, true

Frivolity.

Frugality .

GAIETY.

Gallantry .

Generosity

Generous

affection

Genius

Gentility .

Girlhood .

Give me your good wishe

Gladness .

Glory

Glory. Immortality

Glorious beauty

Goodness

Good edueation

Good wishes

Good-nature

Gossip

Grace

Graee and elegance.
- Water Willozus.

Damask Rose. Acacia. Ivy.

- Blue Periwinkle.

Oak-leaved Geranium. Arbor Vite.

- London Pride.

- Chicory. Endive.

- Butterfy Orchis. Yellow

- Sweet William. [Lily.

Orange Tree.

devoted

French Honeysuckle.

Plane Tree.

- Corn Cockle.

White Rosebud.

Sweet Basil.

Myrrh.

- Laurel.

- Daphne.

- Glory Flower.

- Bonus Henricus. Mer-

- Cherry Tree.

- Swect Basil.

[cury.

White Mullein.

Cobcea.

Multiflora Rose.

- Yellow Fasmine. 
Grandeur .

Gratitude

Grief

HAPPY love

Hatred

Haughtiness

Iealth

Iermitage

Hidden worth

High-bred

Holy wishes

Honesty .

Hope in adversity

Hopeless love .

Hopeless, not heartless

\section{IIorror}

Hospitality

Humility .

I AM too happy

I am your captive

I am worthy of you .

I ehange but in death
Hope

- Ash Tree.

Small White Bell-flower. Harebell. Marigold. Bridal liose.

- Basil.

- Purple Larkspur. Sun

- Iceiand Moss. [ flower.

- Milkwort.

- Coriander.

- Penstemon Azureum.

- Plumbago Larpenta.

- Honesty.

- Hawthorn. Snowdrop. Flowering Almond.

- Spruce Pine.

- Yellow Tulip.

- Love Lies Bleeding.

- Mandrake. Diagonswort.

- Oak Tree. [Snakesfool.

- Broom. Small Bindzuecd. Field Lilac.

- Cape fasmine.

- Peach Blossom.

- White Rose.

- Bay Leaf.

I claim at least your esteem Potcntilla.

I dare not

I rleclare against you

I declare war against you

I die if negleeted

Veronica Speciosa.

- Belvidere. Liquorice.

- Laurestina.

I desire a return of affeetion Fonquil.

I feel my obligations

I have lost all : $\quad$. Mourning B

I love
- Lint.

- Mourning Bride.

- Cedar Leaf.

Red Chrysinthemum. 
i offer you my all . Shepherit's Purse.

I offer you my fortunc, or, I offer you pecuniary aid Calceolaria.

I share your sentiments . Double China Aster.

I shall die to-morrow

I shall not survive you

I surmount difficulties

I watch over you

I wcep for you .

I will think of it

I wound to heal

Idleness

If you love me you will find it out

Ill-naturc .

Ill-natured bcauty

Imagination .

Impaticnce

Impatient of abscnce Impaticnt resolves. Imperfection .

Importunity

Inconstancy

Incorruptible

Independence .

Indifference

\section{Indolenee}

Industry .

Industry, domestic .

Ingeniousness .

Ingenuitv
Garden Daisy.

- Gun Cistus.

- Black Mulberry.

- Mistletoe.

- Mountain Ash.

- Purple Verbena.

- Single China Aster. Wild Daisy.

- Eglantine (Swectbrier). - Mesembryanthemam.

- Maiden Blush Rose.

- Crab Blossom

- Citron.

- Lupine.

- Yellow Balsam.

- Corchorus.

- Red Balsam.

- Henbane.

- Burdock.

- Evening Primrose.

- Cedar of Lebanon. [Oak.

- Wild Plum Tree. IVhite

- Everfuzvering Candytuft. Mustard Secd. Pigcon Berry. Senzy. - Mitraria Coccinea.

- Red Clover.

- Flax.

- White Pink. Pencillal Geranium. 
Ingenuous simplicity

Ingratitude

Innoccnec

Insinccrity

Insinuation

Inspiration

Instability

Intellect .

Intoxication

Irony

JEALOUS:

Jcst .

Joys to come
Justice

Justice shall be done to you

KEEP your promise. Kindness .

Knight-crrantry

LAMENTATION

Lasting beauty

Lasting pleasures

Let me go

Levity

Liberty

Lile .

Lighthcartedness

Lightness

Live for me

Love

I.ove, forsaken

Love, returned

Love is dangerous .

I ove for all scasous .
- Mouse-eared Chickweal.

- Crovefoot.

- Daisy.

- Foxglove.

- Great Bindzvide.

- Angelica.

- Dahlia.

- Walnut.

- Vine.

- Sardony.

- French Marigold. Yellow

- Southernwood.

- Lesser Celandine.

- Rudbeckia.

to

- Coltsfoot, or Szueet-scented

- Petunia.

- Scarlat Giranium.

- Helmet Flozver (Monkis hood).

- Aspen Tree.

- Stock.

- Everlasting I'ea.

- Butterfly ithcel.

- Larkspur.

- Live Oak.

- Luccrn.

- Shamrock.

- Larkspir.

- Arbor Vitro.

- Myrtle. Riose.

- Crecping IVillua.

- Ambrosia.

- Carolina Rose.

- Furze. 
182 The Language of Flowers.

Lustre

Luxury -

Majesty

Make haste

Malevolenee

Marriage .

Maternal affeetion

Maternal love .

Maternal tenderness

Matrimony

Matronly graee

Mature charms

May you be happy

Meanness

Meckness

Melaneholy

Mental beauty

Message .

Mildness .

Mirth

Misanthropy

Modest beauty

Modest genius .

Modesty .

Modesty and purity.

Momentary happiness

Mourning

Musie

My best days are past
- Aconite-leaved Crowfoot. or, Fair Maid of France.

- Chestnut Tree. Calla AEthiopica.

- Crown Imperial.

- Dianthus.

Lobelia.

- Ivy.

- Cinquefoil.

- Moss.

- Wood Scrrel.

- American Linden.

Cattleya.

Cattley'e Pineli.

Volkamenia.

Coscuta.

Birch.

[Leaves.

- Dark Geranium. Dúd Clematis Kennedia. Iris.

Mallowe.

Saffion Crocus.

- Aconite (Wolfsbane). Fuller's Teazle.

- Trillium Pictum.

- Creeping Cereus.

- Violet.

- White Lily.

- Virginian Spidernort.

- Wceping Willow. Bundles of Reeds with their Panicles.

Colchicum, or Meaduw Suffron. 
My regrets follow you to the grave. . Asphodel. NeAtness . . . Broom.

Neglected beauty . . Throatwort.

Nevcr-ceasing remembrance. . Everlasting.

Never despair . . . Watcher by the Wayside.

Night . . . Night Convolvulus.

No. . . . Snapdragon.

OLD age . . . Tree of Life.

Only deserve my love - Campion Rose.

PAINFUL recollections . Flos Adonis.

Painting . . . Auricula.

Painting the lily . . Daphne Odora.

Passion . . . White Dittany.

Patcrnal error . . . Cardamine.

Patience. . . Dock. Ox-eye. ltium.

Patriotism . . American Elm. Nastur-

Peace . . Olive.

Perfectcd lovelincss: : White Camellia fapon-

Perfidy . . . . Common Laurel in flozver

Pensive beauty . . Laburnum.

Perplexity . . . Love in a Mist.

Persecution . . . Checkered Fritillary.

Perseverance . . . Swamp Magnolia.

Persuasion . . Althea Frutex. Syrian Mallow.

Pertinacity . . . Clotbur.

Pity. . . . Pine, also Andromeilis.

Pleasure and pain . Dog Rose.

Pleasure, lasting . Everlasting Pea.

Pleasures of mentiory . White Perizuinkle.

Popular favour . . Cistus, or Rock Rose.

Poverty . . . Evergreen Clematis.

Power . . . . Impcrial Montague. 
Pray for me -

Prccaution

Predietion

Pretension

Pride

Privation -

Profit

Prolibition

Prolific -

Promptness

Prosperity

Protection

Pure love -

Pure and ardent love

Pure and lovely

Purity

Quariel

Quicksightcdness

READY armed -

Reason -

Recantation -

Reeall

Reconeiliation -

Refincment

Refusal

Regard

Regret

Rclicf

Relicve my anxicty -

Religious superstition, or faith

Religious enthusiasm

Rcmcmbranec - -

Remorse -
- White Verbena.

- Golden Rod.

- Prophetic Marigola.

- Spiked Willow Herb.

- Hundred-leaved Rose. Amaryllis.

- Indian Plum. Myrobalan

- Cabbage.

- Privet.

- Fig Tree.

- Tel-zveek Stock.

- Beech Tree.

- Bearded Crepis.

- Single Red Pink.

- Double Red Pink.

- Red Rosebud.

- Star of Bethlehem.

- Broken Corn-strazo.

- Hawkzueed.

- Gladivli.

- Goat's Rue.

- Lotus Leaf.

- Silver-leaved Geranium.

- Filbert. Hazel.

- Gardenia.

- Striped Camation.

- Daffodil.

- Purple Verbena.

- Balm of Gilead.

- Christmas Rose.

- Passion Flower.

- Schinuls.

- Rosemary.

- Bramble. Raspbeiry. 
Rendezvous

Reserve -

Resistance

Resolved to be noticerl

Restoration

Retaliation

Return of happiness

Revenge -

Reverie

Reward of merit

Reward of virtue

Riches

Rigour

Rivalry

Rudeness

Rural happiness

Rustie beauty

Rustic oraele -

SADNESS -

Safety

Satire

Seulpture -

Seeret love

Semblanee

Sensitiveness -

Sensuality

Separation

Severity -

Shame

Sharpness

Siekness -

Silliness -

Simplieity

Sincerity -
- Chichweed.

- Maple.

- Tremella Niestoc.

- Siphocampylos.

- Persicaria.

- Scotch Thistle.

- Lily of the Valley.

- Birdsfoot Trefoil.

- Flowering Fern.

- Bay Wreath.

- Garland of Roses.

- Corn.

- Lantana.

- Rocket.

- Clotbur. Xanthius.

- Yellow Violet.

- French Foneysucklé.

- Dandelion.

- Dead Leaves.

- Traveller's Foy.

- Prickly Pear.

- Hoya.

- Yellow Acacia.

- Spiked Speedruell.

- Mimosa.

- Spanish Fistnine.

- Carolina Jasmine.

- Branch of Thorns.

- Pcony.

- Barberry Tree.

- Anemone (Zephyr Flower).

- Fool's Parsley.

- American Szuetbriar. Gurden Cherril. 


\begin{tabular}{|c|c|c|c|c|}
\hline Slighted & love & - & - & - Yellow Chrysanthemum. \\
\hline Snarc & 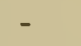 & - & - & - Catchfy. Dragon Plani. \\
\hline Solitude & - & - & - & - Heath. \\
\hline Sorrow & 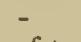 & - & - & - Yew. \\
\hline Sourness & of tc & inper & - & - Barberry. \\
\hline Spell & - & - & - & - Circe. \\
\hline Spleen & - & - & - & - Fumitory: \\
\hline Splendid & beau & & - & - Amaryllis. \\
\hline Splendou & & - & - & - Austurtium. \\
\hline Sporting & & - & - & - Fox-tazl Grass. \\
\hline Stoicism & plety & $\begin{array}{l}y \\
-\end{array}$ & - & - Box Trce. \\
\hline Strength & - & - & - & - Cedar. Fennel. \\
\hline Stupidity & & - & - & - Horseshoc-leaf Geranium. \\
\hline Submissi & & & - & - Grass. Harebell. \\
\hline Success $e$ & everyw & where & & - Nemoplizila. \\
\hline $\begin{array}{l}\text { Success c } \\
\text { Succour }\end{array}$ & row & you & Wisnes & $\begin{array}{l}\text { es Coronella. } \\
\text { - Funiper. }\end{array}$ \\
\hline Such wor & th is & rare & - & - Achimenes. \\
\hline Sunbeam & ing $\mathrm{c}$ & yes & - & - Scarlet Lychnis. \\
\hline Surprise & - & - & - & - Trufle. \\
\hline Susceptib & jility & - & - & - Wax Plant. \\
\hline Suspicion & & - & 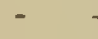 & - Champignon. \\
\hline Sympathy & & - & - & - Balm. Thrift. \\
\hline TALENT & & - & - & - White Pink. \\
\hline Tardincss & & - & - & - Flax-leaved Golden-locks. \\
\hline Taste & - & - & - & - Scarlet Nuschia. \\
\hline $\begin{array}{l}\text { 1 ears } \\
\text { Tcmperar }\end{array}$ & nce & - & - & - Azalea. \\
\hline Temptati & & - & - & - Apple. \\
\hline Thankful & ness & - & - & - Agrimony. \\
\hline The color & ur of 1 & my fat & & - Coral Honeysuckie. \\
\hline 'The heart & t's my & istery & & - Crimson Polyanthus. \\
\hline & ectic & 101 & tet & \\
\hline & & & & $-J u s c a r a z$ \\
\hline
\end{tabular}


The witching soul of music Oats.

The variety of your eonversation delights me - Clarkia.

There is no unalloyed good Lapagenia Rose.

Thoughts - - - Pansy.

Thoughts of absent friends Zimnia.

Thy frown will kill me - Currant.

Thy smile I aspire to - Daily Rose.

Ties - - - - Tendrils of Climbing Plants.

Timidity - - - - Marvel of Peru.

Time - - - - White Poplar.

Tranquillity - - - Mudwort. Stonecrop.

Tranquillise my anxicty - Christmas Rose.

Transicnt beauty - - Night-blooming Cereus.

Transport of joy - - Całe Fasmine.

Treachery

- Bilberry.

True love

True friendship

Truth

- Forget-me-not.

- Oak-leaved Geranium.

- Bittersweet Nightshade.

Unanimity - - - Pllox.

Unbelicf - - - Fudas Tree.

Unceasing remembrance - American Cudweed.

Unehanging fricndship - Arbor Vita.

Unconscious beauty

Uncxpccted meeting

Unfortunate love -

- Burgundy Rose.

- Lemon Geraniusi.

Union

- Scabious.

Unity

Unitc against a common foe - - - - Scarlet Verbeni.

Uprightncss - - - Imbricata.

Uselcssness - - - Mleadozusweet.

Utility - - - - Grass. 


\begin{tabular}{lll}
\hline VARIETY - & - & - \\
Vice - & - & - \\
Victory - & - & - \\
Virtue - & - & - \\
Virtuc, domestic & - \\
Volubility - & - \\
Voraciousness - & - \\
Vulgar ninds - & - \\
WAR - & -
\end{tabular}

Warlike tropliy

Warmth of fccling
- China Aster. Mundi Rose

- Darnel ( liay Grass).

- Palm.

- Mint.

- Sage.

- Abecedary.

- Lupinc.

- African Marisoli.

- York and Lancaster Rose. Achillea Millefolia.

- Intian Cress.

- Peppermint.

- Musk Plant.

- Westeria.

- American Sturwort.

- Swcet Scabious.

nc

- Stephanotis.

Will you dancc with me? Viscaria Oculata.

Win me and wcar me - Lady's Slipper.

Winning grace - $\quad$ - Coroslip.

Winter agre - - - Guelder Rose.

Wisdom - - - - Blue Salvia.

Wit - - - : Meadow Lychnis.

Witchcraft - - - Enchanter's Nightshadc.

Worth bcyond bcauty - Sweet Elysium.

Worth sustained by jucli-

ciousand tenderaffcction Pink Convolvulus.

Worldliness, self-secking - Clianthus.

Worthy of all praise - Fennel.

You are cold - - $\quad$ - Hortensia.

You are nuy divinity - American Conoslip.

You are perfect - - Pine Apple.

You are racliant with

charms - . . - Ranunculus. 
You are the quecn of coqucttes - - - Qucen's Rocket.

You are charming - - Leschenaultia Splendens.

You have no claims - - Pasque Flower.

You have many lovers .. Chorozema Varium.

You please all - - - Branch of Currants.

You are too bold - - Diplademia Crassinoaia.

You will be my death - Hemlock.

Your charms are engraven

on my heart - - - Spindle Trce.

Your looks freeze me - Ice Plant.

Your presenee softens my pain - - - - Milkuctch.

Your purity equals your loveliness - - - Orange Blossoms.

Your qualities, like your charms, are uncqualled Peach. Your qualities surpass your charms -

- Mignonette.

Your temper is too hasty - GrammanthesChlorafore Youthful innocence - - White Lilac. Youthful love - - - Red Catchfy. Yourwhims are unbearable Monardi Amplexicenitis. ZrALOUSNESS - - Elder. 'Lest - - - - Lcmon.

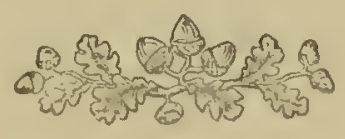




\section{MODIFICATIONS OF THE FLOWEI LANGUAGE.}

If a flower be given reversed, its original signification is understood to be eontradieted, and the opposite meaning to be implied.

A rosebud divested of its thorns, but retaining its leaves, eonveys the sentiment, "I fear no longer; I hope ;" thorns signifying fears, and leaves hopes.

Stripped of leaves and thorns, the bud signifies, "There is nothing to hope or fear."

The expression of flowers is also varied by ehanging their positions. Place a marigold on the hend, and it signifies, "Mental anguish;" on the bosom, "Indifferenee."

When a flower is given, the pronoun $I$ is under. stood by bending it to the right hand; thou, by inelining it to the left.

"Yes" is implied by touehing the flower given with the lips.

"No," by pinching off a petal, and easting it away.

"I am" is expressed by a laurel-leaf twisted round the bouquet.

"I have," by an ivy-leaf folded together.

"I offer you," by a leaf of the Virginian Creeper. 


\section{BOUQUETS.}

I. - Remember our rendezvous, but bcwarc of a false friend.

I. Remcmbrance . Rosemary.

2. Rendezvous . Chickweed.

3. Beware of false friends Franciscea Latifolia.

II.-Our unexpected meeting left but transient impressions.

Answer-Vulgar minds soon forget.

I. Unexpected meeting . Lemon Geranizm.

2. Transient impressions. Withered White Rose.

3. Vulgar minds . . African Marigold.

4. Forgetfulness . Moonzort.

III.-My fortitude forsook me on your refusal to be mine.

I. Fortitude

2. Forsaken

3. Rcfusal

4. Bc minc

- Dipteracanthus Specta-

- Laburnum.

- Strifed Carnation.

- Four-leaved Clover.

IV.-Do not refuse to come down and comfort my solitude.

I. Do not rcfuse

2. Come down

3. Comfort

4. Solitude
- Escholzia.

- Facob's Ladder.

- Pear Tree.

- Heath.

V.-Your affectation and deceit I disdain.

I. Affectation .

2. Deccit .

3. Disdain
- Cockscomb Amarantß.

. Fly-trap.

- Yellow Carnatior. 
VI.-I love to disappoint your curiosity.
I. Love
- Red Rose.
2. Disappoint .
3. Curiosity .
- Carolina Syringa.
- Sycamore.

VII.-I am docile and dejected, do not refusc rne.

I. Docile.

2. Dejected . . Lichen.

3. Do not refuse . . Carrot Flower.

VIII.-I hope you may be happy, and offer you pecuniary aid.

I. Hope . . . . Flowering Almond.

2. May you be happy . Volkaminia.

3. Offer pecuniary aid . Calceolaria.

IX.-Be tempcrate in your taste.

I. Tempcrance . Azalea.

2. Tastc . . . Scarlet Fuschio.

$\mathrm{X}$.- - Let the bonds of marriage unitc us.

I. Bonds .

- Biue Convoluulus.

2. Marriage . . Ivy.

3. Unite us . . A few whole Straws.

XI.-Mcet me to-night; do not forget.

I. Meet me

2. To-night

3. Do not forget

XII.-I wcep for your indifferencc, and am melancholy on account of your coldness.

I. I wcep for you . . Purple Verbena.

2. Indiffercnce . . Musturd Seed.

3. Mclancholy . . Dead Leaves.

4. Colduncss . . Agnus Castus. 


$$
x / A
$$



